\title{
ETHICAL ISSUES CONCERNING THE VISUAL REPRESENTATION OF SHATILA REFUGEE CAMP
}

\section{NG HWEE CHIN}

\section{School of Art, Design and Media}

A thesis submitted to the Nanyang Technological University in partial fulfilment of the requirement for the degree of Master of Arts
Formatted: Font: Bookman Old Style, 14 pt, Not Bold, Font color: Auto

Formatted: Centered

Formatted: Font: Not Bold, (Intl) Bookman Old Style

Formatted: Font: (Intl) Bookman Old Style

Formatted: Centered

Formatted: Font: Bookman Old Style, Not Italic, Font color: Auto

Formatted: Font: (Intl) Bookman Old Style Formatted: Centered

Formatted: Font: Not Bold, (Intl) Bookman Old Style

Formatted: Centered, Indent: Left: $0 \mathrm{~cm}$

Formatted: Font: Bookman Old Style

Formatted: Centered, Indent: Left: $0 \mathrm{~cm}$, First line: 


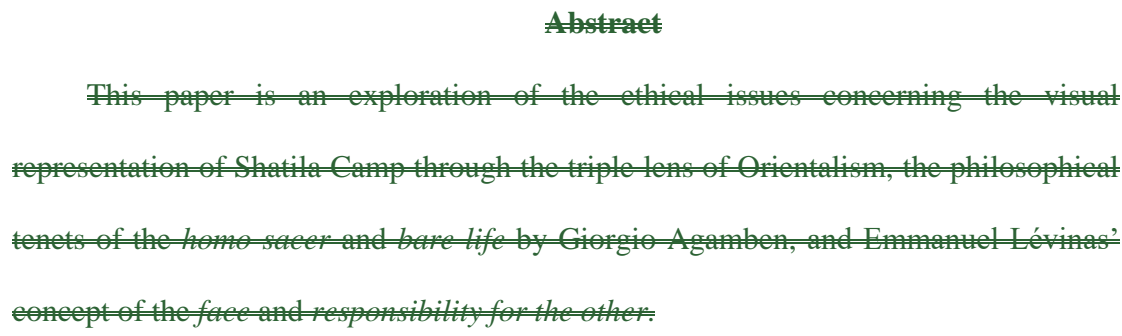

\section{Acknowledgement}

I would like to acknowledge everyone at Nanyang Technological University and the Middle East Institute of Singapore, National University of Singapore who have guided me in the journey towards the completion of my Master's degree so far.

First and foremost, I would like to give my thanks and deepest appreciation to my main supervisor Asst. Prof Kenneth Feinstein for his complete dedication, insightful guidance and invaluable advice for the last eight months. I would also like to thank my co-supervisor Dr. James Dorsey for his perceptive views, prompt responses and immense help provided in the past two years. I have been very fortunate and honoured to be under the tutelage of these two wonderful mentors and I deeply respect both of them.

I would also like to thank Prof Michael Walsh and Ms. Hong Bee Kuen for their advice regarding graduate school matters, as well as Nan Triveni Achnas and Lea Vidakovic for their kind assistance.

Last but not least, a very special thanks to the people of Shatila Refugee Camp for allowing me to enter their world and lives, without which this photo project and thesis would not have been possible. 


\section{Table of Content}

Title Page

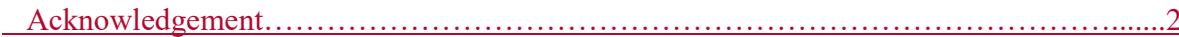

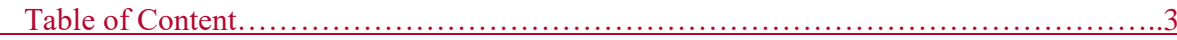

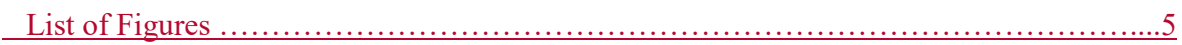

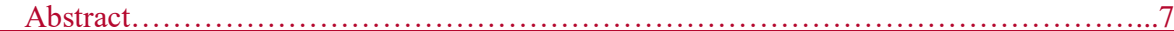

\section{CHAPTER 1}

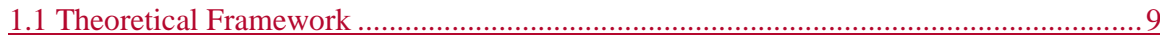

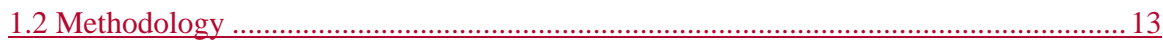

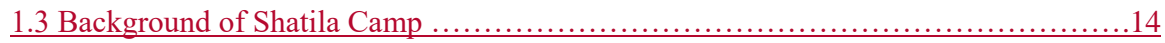

1.4 Relationship between Shatila Camp and Lebanon ................................................ 15

1.5 The Palestinian refugee as a homo sacer ............................................................... 16

1.6 What does the concept of 'camp' mean to Palestinian refugees? ...................................17

1.7 Double marginalisation of Palestinians in Lebanon and within Shatila Camp ................18

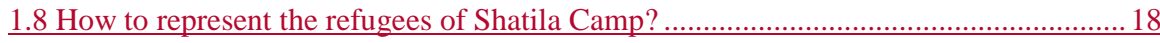

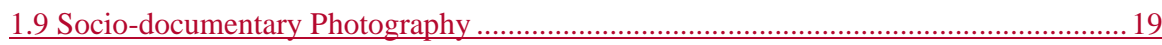

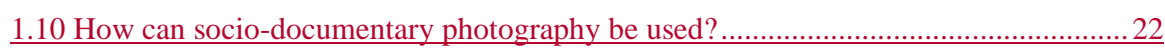

1.11 Positive impact of documenting Shatila Camp ........................................................... 24

1.12 Negative impact of documenting Shatila Camp ………............................................. 24

1.13 Leading a bare life in Shatila Camp ........................................................................... 26

1.14 Limitations of using socio-documentary photography ...........................................2.

\section{CHAPTER 2}

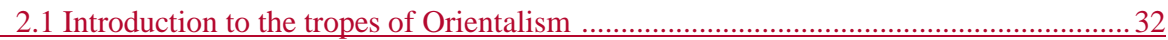

2.2 An Orientalist view of the Middle East through early $19^{\text {th }}$ century paintings ...............33

2.3 An Orientalist view of the Middle East through photography .................................... 35

2.4 Photographic representation of refugees in the media .................................................. 38

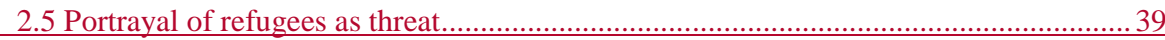

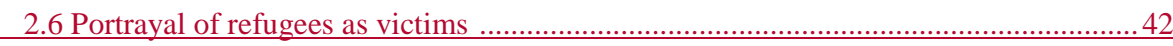

2.7 Photographic representation of Shatila Camp by other photographers ........................ 43 


\section{CHAPTER 3}

3.1The portrayal of Oriental women in $19^{\text {th }}$ century paintings .........................................53

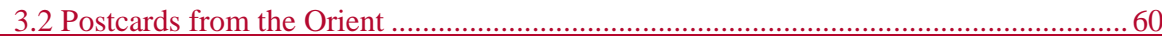

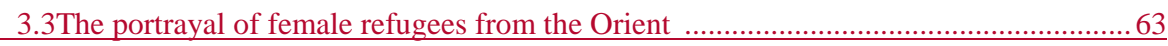

3.4The portrayal of female refugees in Shatila Camp .........................................................6

3.5 Rania Matar - A Girl and Her Room …….............................................................. 71

3.6 Zeinab's story: Giving a face to Shatila's residents ...................................................... 78

3.6.1 Seeing Zeinab's life through Portraiture ………...................................................... 80

3.6.2 Seeing Zeinab's life through Environmental Portraiture ....................................... 82

\section{CHAPTER 4}

4.1 Analysis of the works of Jacob Riis and Sebastiàn Liste ............................................ 86

4.2 Comparing the works of Sebastião Salgado and James Nachtwey vis-à-vis the documentation of Shatila Camp.......................................................... 88

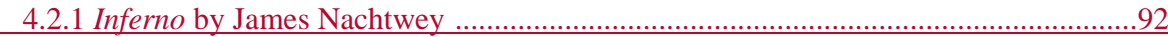

4.3 Ethical considerations regarding the visual portrayal of Shatila Camp ..........................96

4.3.1 The ethical role of a photographer ............................................................................. 97

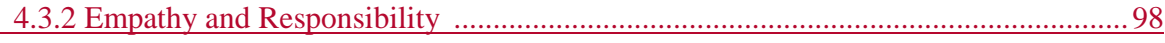

4.3.3 Photographing daily life in Shatila Camp …………………………….................. 99

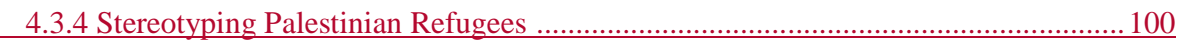

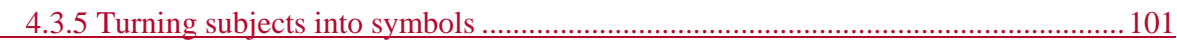

4.3.6 Ruin Porn? - Photographing the architectural ruins of Shatila Camp .....................102

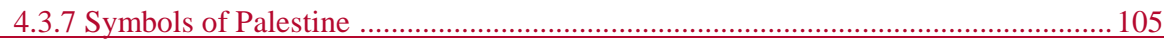

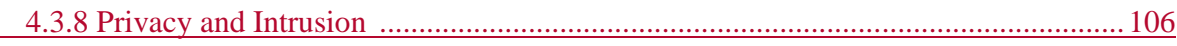

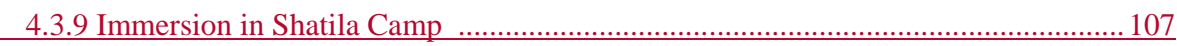

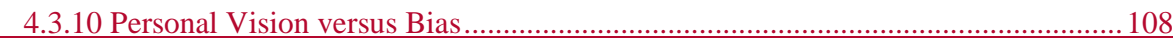

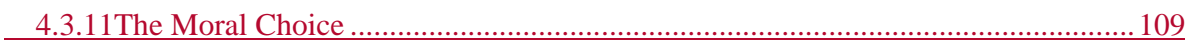

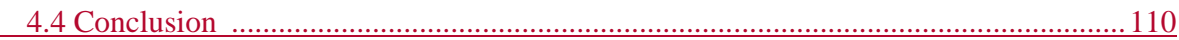

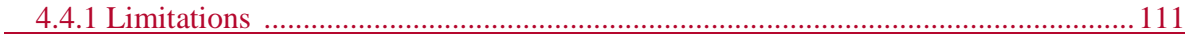

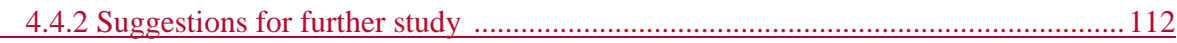

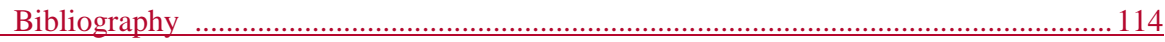

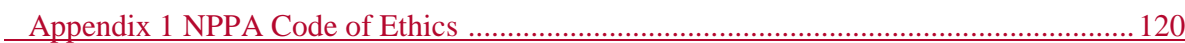

Appendix 2 Practical Component (Photos of Shatila Camp)............................................ 123 


\section{List of Figures}

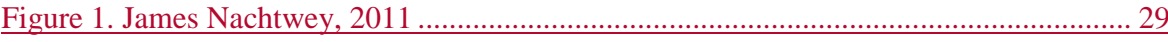

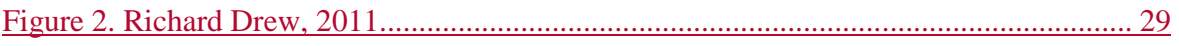

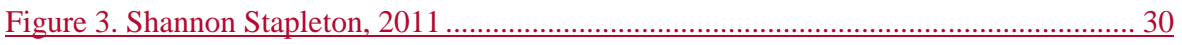

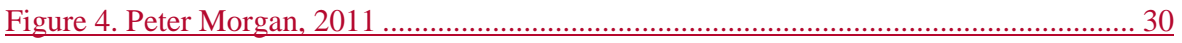

Figure 5. Fran Wilhem Odelmark, In the Souk, 1898 …................................................... 34

Figure 6. Jean-Léon Gérôme, Le Charmeur de Serpent, 1880 ............................................ 35

Figure 7. Agence France-Presse, Supporters of the Shia cleric Moqtada al-Sadr marched towards the Green Zone, where the government is based, Iraq, 2016 .................. 36

Figure 8. Yahya Arhab, Tribesmen gather to support Yemen's Shia Houthi rebels, 2015 ... 37

Figure 9. Abed Omar Qusini, Jenin Refugee Camp, the West Bank, 2017 ............................ 38

Figure 10. Hassan Ammar, Salaheddine, Aleppo, Syria, 2017 ......................................... 38

Figure 11. Eugène Delacroix, Christ asleep during the Tempest, 1853,

H. O. Havemeyer Collection, Bequest of Mrs. H. O. Havemeyer, 1929 _............ 40

Figure 12. Massimo Sestini, Rescue Operation, 2014 ................................................... 40

Figure 13. Niloufar Demir, Lifeless body of Aylan Kurdi, 2015 ........................................ 42

Figure 14. Corentin Fohlen, Hunger, 2015 .............................................................. 43

Figure 15. Hussein Malla, Al Quds Day Commemoration in Shatila Camp, 2014 ............... 45

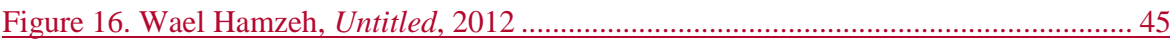

Figure 17. Chris Steel Perkins, Sabra-Shatila Massacre, 1982 ……................................... 46

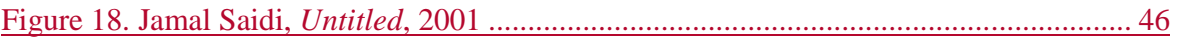

Figure 19. Andrew McConnell, Untitled, 2013 ................................................................. 47

Figure 20. Jens Schwarz, Shatila and Burj el-Barajneh series, 2008 …............................ 50

Figure 21. Jens Schwarz, Shatila and Burj el-Barajneh series, 2008 ................................ 51

Figure 22. Jean-Léon Gérôme, Slave Market, 1866,

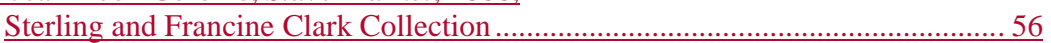

Figure 23. Jean Auguste Dominique Ingres, Turkish Bath, 1862 …..................................... 57

Figure 24. Jean Auguste Dominique Ingres, Grande Odalisque, 1814 ….............................58

Figure 25. Eugène Delacroix, Women of Algiers in their apartment, 1834,

Musée du Louvre................................................................................................. 59

Figure 26. Arabian Nights Harem Nude Courtesan Waiting in Bed, 1910s,

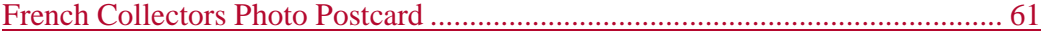

Figure 27. Félix Jacques Moulin, A Moorish woman with her maid, 1856 .......................... .61

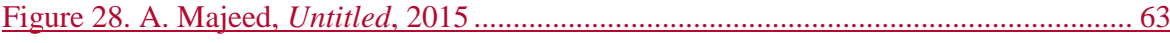

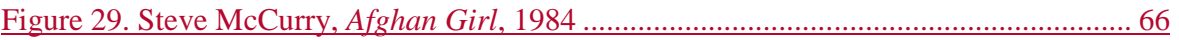

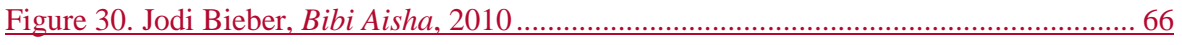

Figure 31. Sebastião Salgado, Refugee from Gondan Mali, 1985 .....................................6 66

Figure 32. Giovanni Battista Salvi II Sassoferrato, Madonna and Child, 1609-1685 ......... 68

Figure 33. Lyndsey Addario, Taimaa Abazli, 24, holds her new baby Heln in their tent at the Karamalis camp in Thessaloniki, Greece, 2016 
Figure 34. Palestine Chronicle, The Sabra-Shatila massacre was just one of Sharon's terrorist achievements on behalf of the state of Israel, 1982

Figure 35. Sharif Karim, A Palestinian woman reacts as she carries portraits of her relatives who were killed during the Sabra-Shatila massacre in a march to mark the 32nd anniversary of the massacre in Beirut September 19, 2014.......... 70

Figure 36. Mohamed Azakir, A Palestinian woman mourns the death of Palestinian President Yasser Arafat in Shatila Refugee Camp in Beirut November 11, 2004.

Figure 37. Rania Matar, Elham, Shatila Refugee Camp, Beirut, Lebanon, 2009.................. 76

Figure 38. Rania Matar, Hiba, Shatila Refugee Camp, Beirut, Lebanon, 2010 ...................... 76

Figure 39. Rania Matar, Amal, Shatila Refugee Camp, Beirut, Lebanon, 2010 ..................... 77

Figure 40. Rania Matar, Christilla, Rabieh District, Greater Beirut, Lebanon, 2010............ 77

Figure 41. Zann Huizhen Huang, Portrait of Zeinab, 2012 ….............................................. 80

Figure 42. Zann Huizhen Huang, Zeinab and her workspace outside her rented home.

Her son is carrying the baby of her daughter, 2012 ............................................. 83

Figure 43. Sebastião Salgado, Sahel-The End of the Road,

Korem Camp, Ethiopia, 1984........................................................................ .90

Figure 44. Sebastião Salgado, Sahel - The End of the Road,

Korem Camp, Ethiopia, 1984.

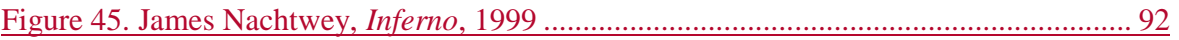

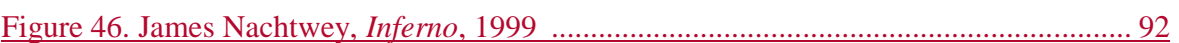

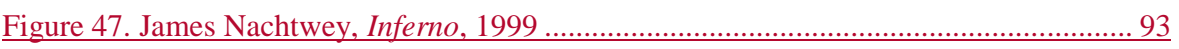

Figure 48. James Nachtwey, Inferno, 1999 ............................................................. 93

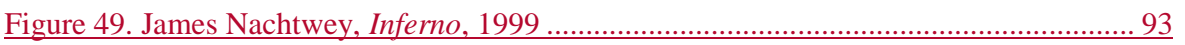

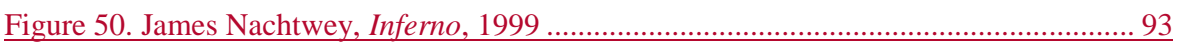

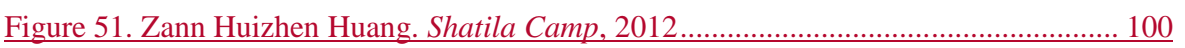

Figure 52. Zann Huizhen Huang, Shatila Ruins, 2012 .................................................. 103

Figure 53. Zann Huizhen Huang, Shatila Camp, 2012 ....................................................... 107 


\section{$\underline{\underline{\text { Abstract }}}$}

This paper is an exploration of the ethical issues concerning the visual representation of Shatila Camp through the triple lens of Orientalism, the philosophical tenets of the homo sacer and bare life by Giorgio Agamben, and Emmanuel Lévinas' concept of the face and responsibility for the other.

The visual portrayal of the camp will be examined vis-à-vis works by a few selected photographers. Thereafter, the analysis of these photographers' works will be used to reflect on my own photo-documentation of Shatila Camp and its residents.

Although the concepts of Orientalism originated from literary works, the discourse of this paper will be confined to the visual arts - namely paintings and photography. To illustrate the concept of Orientalism, some salient paintings and photographs will be examined. The discussion will be divided into:

3.1. How the Orientals have been portrayed,

4.2. How Oriental women have been portrayed in relation to the photodocumentation of Zeinab - the central figure in the visual component of this thesis as well as selected images by Rania Matar and

5.3. How the residents of Shatila Camp have been portrayed by other photographers.

This will elucidate how the influences that paintings, the predecessor of photography, have had on the latter. Through this process, we will discover how Orientalism has shaped and influenced artists over the centuries. We will also unpick how its traits have been reinvented, reformed and resurfaced into contemporary times in the various guises of visual art - be it consciously or sub-consciously. 
The Palestinian refugees are largely being excluded from Lebanese political and civil society as well as the world at large as a result of their statelessness (UNHCR 2016, 5). It is essential to apply the concept of the homo sacer by Agamben and relate it to how the stateless Palestinian refugees living in Lebanon are leading what he refers to as bare life in relation to their Lebanese counterparts, who enjoy the protection and rights of being a citizen of a sovereign state. Lacking most civil rights (UNWRA 2016), Palestinian refugees can be collectively regarded as the homo sacers of Lebanon which places them in a vulnerable position. The crux of this paper lies in seeking ethical methods to visually represent these refugees, who lack political representation and to minimize the negative impact of photographing them. Lévinas' concept of one's ethical responsibility to the other will also be employed as a moral guideline to direct how one should treat the refugees.

Through the multi-layered approach of exploring the ethical issues which may arise in the process of documenting Shatila Refugee Camp, it can contribute to raising the awareness of visual artists who may unconsciously adopt and revamp characteristics of Orientalism into their work. This will hopefully enable future artists or photographers to be more conscious and vigilant in their practice, in view of what Edward Said says, "to reduce the effects of imperialist shackles" (Said 1979, 354). 


\section{Chapter 1}

1.1 Theoretical Framework

The exploration of the ethical issues concerning the visual representation of the residents and life of the Shatila Refugee Camp in Beirut, Lebanon will be critically examined using a three - pronged theoretical framework of:

1. Orientalism,

2. Giorgio Agamben's concept of bare life as that which is excluded from the good life as defined by Aristotle by being part of the body politics or civic society. And the concept of the homo sacer as described by Agamben in his book, Homo Sacer: Sovereign Power and Bare Life (1995). A homo sacer was a man banned from society under the Roman Empire. As a consequence of committing a certain crime, all his rights as a citizen were revoked. Therefore, he could be killed by anyone but since his life is regarded as sacred (in the sense of being excluded from society), he is forbidden from being sacrificed in a ritual as this would reincorporate him back into society. "What, then, is the life of a homo sacer, if it is situated at the intersection of a capacity to be killed and yet not sacrificed, outside both human and divine law?” (Agamben 1995, 73)

3. as well as Lévinas' ontology.

The Orient typically refers to countries that are located to the East of the West i.e. the ex-colonies of Great Britain and France, stretching from Turkey to the Far East such as Japan. The Orient is not so much a physical entity but more of an 'ideological construct' by the Occident or the West (Said 1979, 322). As stated by Edward Said (1979, 205), "Orientalism was the distillation of ideas about the Orient - its sensuality, its tendency to despotism, its aberrant mentality, its habits of inaccuracy, its backwardness."

The fabrication of Orientalism sprang from colonial times, when the West or Occident encountered the 'exotic or untamed' other. Since the beginning of European 
domination of the Levant around 1801, the identification of the Arabs as the 'Oriental other' gradually became reinforced through works of literature, paintings and photography (Said 1979, 26). With the understanding that a person from the Far East can also be regarded as an Oriental, in this paper, we will focus only on the Arabs as the Orientals. Some authors quoted in the paper will also be using the terms 'Arabs and Orientals' interchangeably.

Photography which was invented in 1839 , allowed the colonialists to further exploit and propagate these 'exoticised' views. Through the anthropological documentation of 'natives' as well as the portrayal of the Orient as a backward place in need of help, the Occident used this concept as a way to justify its subjugation and colonisation of the Orient which is in need of "corrective study" (Said 1979, 41).

As Jae Emmerling $(2012,85)$ says, “this representational economy between voyeuristic colonial violence (including tourism) and a form of expository autoethnography results in a complex set of images that Edward Said called a "great fat archive." This 'Orient construct' has been so deeply entrenched that it has come to be regarded as a reality and such mediated representations of the people in the Middle East gave birth to the Orientalist ideology.

The West exerts a form of cultural, political and economic hegemony over the Orient. The Western concept of the Orient is based on, as Edward Said (1979, 300) explains - "the absolute and systematic difference between the West, which is rational, developed, humane, superior and the Orient which is aberrant, undeveloped, inferior." Thus, the West gave itself the license to speak for and to govern the 'silent' other, or the subaltern.

The West had been largely responsible for the perpetuation of such distorted ideas. Whether it is through the lens of writers such as Gustave Flaubert, painters such as Jean 
Auguste Dominique Ingres, photographers such as Félix-Jacques Antoine Moulin or film-makers such as Felice Beato, the Orient has been constructed according to the perspectives of the auteur, "to fashion whatever suits the temper of the times in the West" (Sardar 1999, 53).

The colonial master is typically a white male European with whom one can draw parallel to the modern day, (usually) male Western photojournalists whose mediated view of the Orient has been somewhat shaped (consciously or sub-consciously) by the legacies of the painters and photographers before him. Ziauddin Sardar $(1999,77)$ states that, "pervasive images that were formulated in the Middle Ages have remained in the Western psyche and have been continuously drawn upon, reformulated and reworked into 'modern' scholarship."

The balance of the power of representation is thus tipped in favour of the Orientalist who has the financial capability and privilege to travel to the Orient, to photograph, to speak for, to liberate and to raise awareness for the 'suppressed and exotic other'. The roles that these early photographers played in framing these views still contribute to a very specific societal lens through which the audience sees a skewed version of the Orient.

In addition, both news and aid agencies reinforce this prevailing paradigm of Western superiority since the global flow of information and news have been largely dominated by the Western media such as the British Broadcasting Corporation (BBC), Thomson Reuters and Cable News Network (CNN). Alternative media agencies such as Al Jazeera and other similar non-western news outlets have emerged in the last decade to mitigate the clout of Western dominated media. But outside of the region, Western media is still the predominant voice, according to Said $(1979,108)$ who says that these “contemporary Orientalist attitudes flood the press and the popular mind. Arabs, for 
example, are thought of as camel-riding, terroristic, hook-nosed, venal lechers whose undeserved wealth is an affront to real civilization."

In the $21^{\text {st }}$ century, the portrayal of the modern Middle East is still seen through an Orientalist lens which takes precedence over alternative visual representational modes. In the transcript of an interview with Sut Jhally from the University of MassachusettsAmherst, Edward Said explained,

My interest in Orientalism began for two reasons, one it was an immediate thing, that is to say, the Arab-Israeli War of 1973, which had been preceded by a lot of images and discussions in the media in the popular press about how the Arabs are cowardly and they don't know how to fight and they are always going to be beaten because they are not modern (Jhally 2005, 2).

It is echoed by Ziauddin Sardar $(1999,107)$ who says that, "the distinctive art forms and communication channels of each era recycled standard imagery, iconography and mythology that keeps the past present and Orientalism fully alive and functioning." This in turn side-lines alternative modes of representation like Al Jazeera English, which could potentially be meaningful, into the periphery. Originally perceived as a mouthpiece for the Qatar government in the Western press, AJ America closed down in 2016 (Thielman 2016, par.1).

The proliferation of images of suffering and violence projects the impression that somehow this is intrinsic to life in the Middle East. Again Sardar $(1999,95)$ reminds us that, "the representation of Muslims as inherently violent and deranged characters is as pervasive in the vocabulary of Hollywood films as it is in pot-boiling novels." As a result, the Orient has perpetually been misconstrued in a false and negative light. Therefore, seeking a departure from the formulaic portrayal of the Arabs, my work on the Shatila Refugee Camp and its residents will be used as an example to explore the ethical issues which may arise in the process of photographing. 


\subsection{Methodology}

In this paper, the tenets of Orientalism as stated by Edward Said will be used as guidelines to detect the Orientalist aesthetic found in the paintings and photographs which will be discussed in the following chapters. To decode the aesthetic infused into visual artworks in depicting the language of Orientalism, the semiotic analysis of Roland Barthes' $(1977,35)$ Rhetoric of the Image will be used as a methodological tool to understand how images are interpreted and understood.

According to Barthes $(1977,37)$, a photograph is a visual composition of elements containing two layers of co-existing messages - the literal image which is denoted and the symbolic image which is connoted. In terms of looking at images at a denotational level, the process is independent of socio-cultural contexts. However, in the analysis of images at the connotational level, an element(s) in an image act as signifiers which the viewer interprets, based again on the socio-cultural background of the image maker and viewer. All these elements, both denotations and connotations are tied into a unifying ideology, which in the discourse of this paper, refers to Orientalism.

For the unpicking of Orientalist tropes, the connotations and signifiers of paintings and images will be filtered using Edward Said's characterisation of the Orient. For example, in the painting, In the Souk (1898) by Frans Wilhem Odelmark (figure 5), the Orient is saturated with what Said $(1979,300)$ describes as "an exotic, chaotic and untameable region.” The run-down architecture acts as a signifier of backwardness. The imagery of people, who still ride on camels and donkeys, with some sitting on the ground to ply their trade are used to signify chaos and under-development. These signs will be used to connote the differences of the Orient from the Occident. 


\subsection{Background of Shatila Camp}

Forced into exile following the Al-Nakba which refers to the 'catastrophe' as Palestinians describe their forced exodus from Palestine when the state of Israel was created in 1948, the Palestinian diaspora were scattered mainly to Lebanon, Syria and the Transjordan (Masalha 2009, 37). Displaced for more than six decades, the Palestinians constitute the world's longest standing refugee group and their status remains in a state of limbo. There are a few factors that differentiate the Palestinians' status and collective experiences from other groups of refugees. As compared to refugees of other nationalities such as the Syrians or Afghanis, Palestinians are stateless and deprived of sovereign protection. Moreover, while the United Nations High Commissioner for Refugees (UNHCR) provides assistance to displaced people, the Palestinian refugees are an exception. The United Nations Relief and Works Agency for Palestine Refugees in the Near East (UNRWA) was assigned as its protective mandate. Since 1948, some 425,000 Palestinian refugees living in Lebanon have been registered with UNRWA, the official body mandated to provide basic services such as education to the Palestinian refugees in camps in Lebanon, Jordan, Syria and the Palestinian Territories (UNWRA 2016).

Of the 12 official Palestinian refugee camps in Lebanon, Shatila Refugee Camp the site which will be used as an example in this paper to explore the ethical issues of photographing, has the worst living conditions. According to UNRWA (2016), the camp is severely overcrowded and plagued by a lack of electricity and potable water.

Located in the south of Beirut, Shatila Camp was established to accommodate thousands of displaced Palestinians refugees who were mainly from villages around the area of Amka, Majd al-Krum and Al Yajur in northern Palestine (UNWRA 2016). What started out in 1949 as a temporary refugee camp for Palestinians built by the ICRC (International Committee of the Red Cross), the land allocated for the Shatila Refugee 
Camp has remained the same since its inception at approximately one kilometre square. The congested living conditions in the camp has been exacerbated by the ballooning of its population from about 3,000 in 1949 to a staggering 22,000 in 2015 with Syrians outnumbering Palestinians (Mackenzie 2016, 1).

Over the years, Shatila's population has grown and it has metamorphosed into a space that resembles an urban slum. Offering cheaper rent than the rest of Beirut, Shatila became home to various other refugees from Iraq and Syria, Syrian and Lebanese Romas, Lebanese and migrant workers from South Asia and Africa (Martin 2014, 10).

Yet it was the uprising against Syrian President Assad which started in March 2011 that has effected the most drastic changes in Shatila Camp, both demographically and physically. Shatila has borne the brunt of the huge influx of Syrian refugees due to its central location and affordability in Beirut, where rents are sky high (Ataman 2015, par. 2).

The massive inflow of Syrian refugees into Shatila in the last five years spotlights the evolution of the camp affected by the civil war in neighboring Syria. To date, this has been the largest inflow of non-Palestinians into Shatila Camp.

\subsection{Relationship between Shatila Camp and Lebanon}

Through a historical lens, the factors which have contributed to the tumultuous relationship between the Shatila Refugee Camp and its Lebanese host will be examined.

Due to its strategic location, the Palestine Liberation Organisation (PLO) selected Shatila as its headquarters in Beirut in the 1970s after the Black September incident where the PLO members were driven out of Jordan. The Cairo Accords signed in 1969 allowed an armed Palestinian presence in Lebanon. After the signing of these accords, attacks were launched against Israel with the host country, Lebanon as its base (Solley 1987, 34). 
Largely blamed for the civil war in Lebanon (1975-1990), Palestinians have been systematically denied various civil rights. Moreover, Shatila Camp suffered severe damage during the War of the Camps from 1985-1988 (Peteet 1996, 27). The most notorious event to strike Shatila and the adjacent neighbourhood of Sabra was the massacre in 1982. From 16-18 Sept 1982, an estimated 800-3000 Palestinians including some Lebanese civilians were brutally murdered over three days by the Kataeb Regulatory Forces, the military wing of the Lebanese Phalangist Party, a Christian nationalist party.

Over the last 68 years, Shatila Camp had undergone both demographic and spatial changes to varying degrees. Many Palestinians moved to Shatila after the Tel al Za'atar and Karantina massacres in 1976. However, Shatila survived its ordeals and instead of collapsing and disappearing like the Tel el Za'atar or Nabattiya camps, it 'flourished' to the point that its population grew and it metamorphosed into a space that resembled more of an overcrowded urban slum (Martin 2014, 10).

1.5 The Palestinian refugee as a homo sacer

A stateless Palestinian refugee living in Lebanon who is not entitled to most civil rights, leads a marginal life and is excluded from the fraternity of the Lebanese society at large. This description bears some semblance to Agamben's concept of the homo sacer. As described by Agamben in his book, Homo Sacer: Sovereign Power and Bare Life (1995), a homo sacer was a man banned from society under the Roman Empire. As a consequence of committing a certain crime, all his rights as a citizen were revoked. Therefore, he could be killed by anyone but since his life is regarded as sacred (in the sense of being excluded from society), he is forbidden from being sacrificed in a ritual as this would reincorporate him back into society (Agamben 1995, 73). To further extend Agamben's point, a Palestinian refugee who lives in Lebanon exists by virtue of his 
exclusion from Lebanese society. The harsh terrain of his bare life is visible from how his rights had been denied in various domains, from the right to own property to the right to work in certain professions. As a result, many Palestinians can only hold seasonal or menial jobs and the unemployment rate is high amongst Palestinians.

The Shatila Refugee Camp is excluded from the rest of Lebanese society as this camp does not receive municipal services such as electricity, potable water and waste collection. The services for the Palestinian refugees come under the umbrella of the United Nations Works and Relief Agency for the Near East (UNWRA) and not the United Nations High Commission for Refugees (UNHCR). UNWRA was created specifically to cater to the needs of the Palestinians displaced since 1948. The infrastructure of Shatila was not built or maintained by the Lebanese authorities but by the Palestinians themselves. Thus, this area carved out for Palestinian refugees exists as a result of its exclusion from the rest of Beirut (Martin 2014, 15).

For the Palestinians who are stateless, according to T.J Demos $(2013,151)$, "Palestine exists as a form of collective consciousness and identification that is based on the absence of a state, an imagined community without a sovereign geography, it thereby presents a challenge to the norms of representation."

1.6 What does the concept of 'camp' mean to Palestinian refugees?

What differentiates a Palestinian camp from any other refugee camps in the world? For this displaced and marginalised group of people living in Lebanon, a camp space represents a 'state within a state' (Hanafi 2008, 86), a temporary home where national consciousness, identity and solidarity had been forged over the last six decades. Thus, Shatila Refugee Camp functions as a microcosm of Palestine. To further cement this idea, Bassem Sirhan (1975, 101-102) explains that, "the people in the Palestinian camps in Lebanon are not just a chance collection of individuals or families brought together by 
some accident." In fact, the organization of the camp is a close replica of the displaced villages in pre-1948 Palestine with families that lived in close proximity still living near each other several generations later... In this way many villages which the Israelis occupied by force... are still, socially speaking, alive and coherent units... there is a common sense of being an uprooted and persecuted refugee community."

1.7 Double marginalisation of Palestinians in Lebanon and within Shatila Camp

For many inhabitants in the camp who had known no other life other than life in Shatila, their economic situation does not allow them to leave while some others chose to stay in order to be close to their extended families, according to long-time camp residents.

Thus, trapped in a perpetual state of limbo, where they probably will never be acknowledged by or integrated into Lebanese society, the 'right of return' to Palestine seems remote after more than six decades of exile. The collective experience of these stateless Palestinians highlights them as a group of doubly marginalised people. Firstly, they are marginalised within Lebanon, and secondly within their own camp space as the huge influx of refugees from Syria into Shatila Camp has outnumbered the Palestinians who have lived there for generations, making them a minority in their own space.

1.8 How to represent the refugees of Shatila Camp?

First of all, if the refugees of Shatila are in need of representation in order to highlight their dire living conditions, how can aesthetics fulfil this role? How can a photographer portray the people and the camp-space in an ethically viable way? Why should they be represented? Is it better to show the world their plight or is it better to be indifferent and leave them alone?

Perhaps Jacques Rancière $(2004,124)$ who accorded art with the potential to effect "shifts in thinking: their potential to not only re-frame the visible but, perhaps more 
crucially, to envision the invisible, interstitial and contested sites (sights) of modernity," has the answers.

\subsection{Socio-documentary Photography}

The genre of social documentary functions as the exploratory tool for the photographic component of this thesis with the Shatila Refugee Camp as the chosen site for long-term documentary engagement.

Long-term socio-documentary photography is an in-depth visual record of various socio-political issues. This genre of photography is a hybrid of aesthetics, personal voices and reportage, driven by socially conscious obligations. The intention of the photographer is to seek to illuminate and open windows into hidden communities or pertinent social issues. The aim is to raise public awareness and possibly inspire positive actions and changes. Unlike press photography that typically covers spot news where the photojournalists act as witnesses to events which transpire spontaneously before them, this genre of photography is long-term in nature and the time needed to accomplish this may span from a few months to years (Newhall 2009; Emmerling 2012; Abbott 2011).

The key reason why socio-documentary photography was adopted for the photodocumentation of Shatila Camp was chiefly due to certain traits inherent in this genre. One of which is that a photographer is required to spend an extended amount of time to immerse herself/himself with the subjects or community in question. This modus operandi is in sharp contrast to that of a parachute photojournalist's who is often on assignments with tight deadlines. Due to time constraints, a parachute photojournalist, as the term suggests, jumps in and out of a news scene just as quickly as s/he has appeared. For some photojournalists who were sent on assignments to a foreign country to cover news, they may have little or no knowledge of the socio-cultural background of the place (for example, the Gaza Strip) and the native language. In this case, they may need to rely 
on translators, fixers and drivers in order to help them navigate the new environment and the society. A fixer may suggest places or subjects for a photojournalist to shoot. In such a scenario, a photojournalist may be taken to a place where many other photojournalists have been taken, presuming that the same few fixers are available and were recommended by other photojournalists. In situations like these, a photojournalist runs the risk of producing images which are generic in nature. Such work might turn out to be perfunctory in nature as it barely scratches the surface of issues due to a lack of time and exposure to the subject matter in depth. Hence the viewers may not be given the 'comprehensive' coverage which is expected of the profession.

According to the preamble of the (NPPA) National Press Photographers' Association Code of Ethics $(2016,1)$, the primary goal of photojournalists is the "faithful and comprehensive depiction of the subject at hand." Operating as trustees of the public, photojournalists have the responsibility to document society and to record its history visually. While being "faithful" pertains to the integrity of a photojournalist, the "comprehensive depiction" of the subject matter forms the core of the choice of using long-term documentary work as this aim is reiterated in point one of the NPPA Code of Ethics $(2016,1)$, "Be accurate and comprehensive in the representation of subjects." In order to achieve a comprehensive coverage of a news event or story, it is imperative to spend enough time to get to know the socio-cultural and political background of the subjects or community in which one is documenting. In this vein, it will do justice to the subjects in terms of portraying them as accurately as possible.

Unlike press photographers or photojournalists on assignments, the work I have done on the Shatila Refugee Camp and its residents was out of my own initiative. The project was self-assigned and self-funded, hence there is no obligation to fulfil the 
demands of a client or an editor. The images produced are thus free from editorial control and constraints.

In cases where on many occasions, Western photographers are sent to the Middle East to cover news, it is imperative to examine their photography and the influence that Orientalism has on their work. Images are to a certain degree fashioned and shaped by the ideological and socio-cultural background of the photojournalist, whether consciously or subconsciously. While a photojournalist strives to document the truth, the act of taking a photograph is an interpretive act, as s/he will filter the situation beforehand, selectively frame the image and decide how best a message should be conveyed. The reliance on one's world view and background in order to make sense of events which may seem foreign can result in images produced that lack adequate understanding of the issues at stake. This is echoed by G. Elizabeth Rice (1980, 161-162) who states that "cultural schemata are... responsible for a sort of 'selective perception' of the world which is common to members of a given culture and which has the effect of imparting a characteristic interpretation to the phenomena under consideration."

Working with various newspapers, magazines or photo agencies which are predominantly found in Europe or the USA, the editorial control over the images and captions submitted are beyond that of the photographer's. Editors make the decision on which photos to publish as well as the decision on the context in which they will be presented. The accompanying captions lend the entire process an additional subjective layer. As Roland Barthes $(1977,25)$ says that captions are repressive to the understanding of images. They create the context in which the images are viewed. As editors are not people on the ground, they tend to reflect the culture and prejudices of their audience. There is a likelihood that the images and captions will be filtered through an Orientalist's 
lens which could potentially lead to the reinforcement of these perennial stereotypes, yielding diluted or distorted depiction of the issues involved. However, it is vital to point out that it does not mean that a Westerner or Western-educated individual will necessarily view the Middle Eastern region through an Orientalist's lens or that only a Middle Eastern person or someone who has grown up in this region is legitimate or 'Oriental' enough to document the Orient.

1.10 How can socio-documentary photography be used?

Socio-documentary photography functions as visual and evidentiary records for preservation, archival and even advocacy purposes (Grady 2008, 4). In the context of the documentation of the Shatila Refugee Camp and its residents, photography serves as an analytical tool for social inquiry. The photographic work on Shatila Refugee Camp can be classified as 'socially concerned' photography. As a photographer, I have spent an extended amount of time to understand life in the camp by embedding myself within the community as an observer. The intention is to create awareness regarding the deteriorating living conditions of the camp and to delineate how the residents cope with their daily hardships. It is hoped that viewers will become more socially aware and maybe the images can potentially become catalysts for positive policy changes in the future.

The decision to adopt documentary photography as the tool for exploring the life and living conditions of the Shatila Refugee Camp has been influenced by the positive policy changes brought about by the works of the following photographers, Jacob Riis, Lewis Hine and W. Eugene Smith. These three prominent figures are all pioneers of advocacy photojournalism and they have exposed corporate, political and societal issues through compelling images. Their seminal works will be discussed further (Newhall 2009, 167-172). 
The tradition of adopting socio-documentary photography as a story-telling technique for advocacy started as early as the late $19^{\text {th }}$ century. In 1888 , one of the pioneers of this genre, Jacob Riis (who had worked as a policeman and reporter in New York City) harnessed flash photography as a tool to expose the sordid living conditions of New York City's crime-infested slums. With the images produced, so much awareness was raised that laws were introduced to provide better tenements housing conditions (Newhall 2009, 167).

Another influential socio-documentary photographer was Lewis Hine. A sociologist by profession, his seminal work on child labour highlighted the dire working conditions of minors. As a result of his work, the first federally sanctioned child labour laws were introduced in 1916 (Collier 1986). Hine stated that he "wanted to show things that had to be corrected" (quoted in Chapnick 1994, 48).

A pioneer of the photo essay, W. Eugene Smith's relentless pursuit in exposing the industrial fallout and maiming effects of mercury poisoning from the Chisso factory on the health of the residents in Minamata, a Japanese fishing village, from 1971-1973 drew worldwide attention. His powerful photographs finally brought justice to the victims in the form of compensation and apologies from the factory. One of his most iconic images from this photo story is that of Tomoka Uemura, a victim of the Minamata disease (a form of mercury poisoning), in her bath, cradled by her mother. Smith (1975) said that through photography, the viewers may, "perhaps feel a greater sense of understanding and compassion for those whose lives are alien to our own. Photography is a small voice. I believe in it. If it is well conceived, it sometimes works." The positive and far-reaching impacts of these photographic works are testament to the power of this medium. 
1.11 Positive impact of documenting Shatila Camp

What positive impact can aesthetic visual representation bring to Shatila Camp and its residents? Can one realistically expect that the Palestinian refugees' living conditions will improve or that they will be granted more rights in Lebanon? Photographs can illuminate hidden issues, open up new channels of discourse and engage the viewers meaningfully as Anthony Downey $(2013,125)$ states, "One of the more pervasive cultural features of modernity, finally, has been the privileged role accorded to art when it comes to the representation and reification of that which modernity has excluded, abandoned and repressed."

Images have the capability to depict not only what is visible to the eye but also the 'invisible' liminal zones such as the Shatila Refugee Camp (a zone of exclusion) and its residents as the homo sacer leading a bare life who are largely side-lined and segregated in Lebanese society. Indeed, for the Palestinians who are cast into the 'zone of exclusion', devoid of state protection and recourse to most civil rights in Lebanon, one of the medium through which the life and struggles of these so-called homo sacer can be represented is via photography.

\subsection{Negative impact of documenting Shatila Camp}

In 1951, Theodore Adorno $(2003,162)$ wrote, “To write poetry after Auschwitz is barbaric." He was referring to the denial of the causes of the atrocities committed by the Nazis in the Auschwitz concentration camp. It also reflects the impossibility of art (in this case photography) to completely mediate and convey the pain and suffering of the subjects involved and that this medium cannot repair the damages done. To further compound the situation, an aesthetic representation of suffering could be regarded as possessing distracting elements which could divert the viewers' attention away from what is really at stake, the tragedy itself. This conundrum is best encapsulated by 
Anthony Downey $(2013,124)$ who said that, "Suffering, in sum, sells; nowhere more so than when it is repackaged for consumption and rendered symbolic of a general condition."

The statement as put forth by Downey causes one to reflect upon how a balance can be achieved in order to avoid over-aestheticising the camp such that the reality will be glossed over by aesthetics. This lingering doubt on whether aesthetics can take on an ethically responsible role was echoed when Ingrid Sischy $(1991,5)$ lambasted Sebastião Salgado's works of the famine in the Sahel series (figures 31, 43 and 44) when she said, "beauty is a call to admiration, not to action." This criticism strikes a similar chord to the photo-documentation of the Shatila Refugee Camp's residents and its living conditions. When aesthetics is used to mediate tragedy, it has the potential to 'anaesthetise' the viewers, especially in the proliferation of clichéd images of refugee camps and their residents. This phenomenon could potentially lead the viewers to experience what Susan Moeller $(1999,2)$ refers to as 'compassion fatigue', which is, "at the base of many of the complaints about the public's short attention span, the media's peripatetic journalism, the public's boredom with international news, the media's preoccupation with crisis coverage." Instead of clinging to the noble and idealistic notion of how photographs can change the world, it could produce the opposite effect of numbing the emotional responses of the viewers who have been over-exposed to images of tragedies or misery.

In the photo-documentation of the Shatila Refugee Camp, how then can a photographer who is an outsider avoid the exploitation of her/his subjects by turning the camp into a sensationalised symbol of suffering or a spectacle and to reduce Palestinians to the conditions of victimhood? The discourse of this paper will be further extended to cover this tension between aesthetics and ethics. The seminal works of various 
photographers, their stylistic features and modes of presentation will be explored in the following chapters. The selected photographic works will be used as a comparison and benchmark vis-à-vis the photo-documentation of the Shatila Refugee Camp. This aim is to negotiate and reconcile the ethical quandaries which may exist in the portrayal of the residents of Shatila as the homo sacer and their relationship with the topography of their liminal camp-space.

\subsection{Leading a bare life in Shatila Camp}

Refugee camps exist in different forms and have their own characteristics, e.g. from Auschwitz, which is an extreme case where we find the "overt bio-politicisation of bare life and the abandonment in extremis of internees to an extra-legal no-man's land" (Downey 2009, 113), to camps as temporary shelter for those displaced by natural disasters and detention camps like Guantanamo Bay.

Each camp has its own unique historical background. Events that have significantly shaped Shatila include the Sabra-Shatila massacre of 1982 and the War of the Camps (1985-1988). Moreover, Shatila became the site of the PLO headquarters. The camp has its own unique demographic composition, comprising not only of Palestinians but of Lebanese, Syrian refugees, Lebanese and Syrian Romas, South Asian and Ethiopians migrant workers (Martin 2014, 10).

If according to Agamben, a homo sacer leads a bare life, then in the case of the residents of Shatila, Palestinians who are considered long-term, protracted refugees, this concept may not seem totally applicable at first glance. Unlike other camps for the Internally Displaced People (IDP), where the refugees are interned, fed and sheltered until a solution is found, in Shatila Camp, the residents are not completely stripped of all rights. They have the freedom to move in and out of the camp, travel anywhere in Lebanon and sometimes even overseas with travel documents issued by the Lebanese 
Authorities. For the Palestinians living in Shatila since its establishment in 1949, many are third or fourth generations refugees. Inside the camp, there is a self-sustaining economy of shops selling daily goods, hairdressers, internet cafes, sandwich and kebab shops, fake DVD shops, car repair shops, water refilling stations, confectioneries, bakeries, wedding shops, souvenir shops, snooker tables and game arcades, water pipe shops and pharmacies for example.

One could also easily argue that this hardly fits the description of a bare life in contrast to the bare life of the Jewish living in concentration camps such as Auschwitz or other spaces of 'exception' such as the detention camps of Guantanamo Bay.

Yet the fact that the refugees living inside Shatila Camp had to resort to creating their own 'domestic' economy is a clear indication of their exclusion from the Lebanese society at large. Though their lives are not exactly bare in the literal sense, it is bare in relation to the rights that Lebanese with citizenship are entitled to. Palestinians are still denied the right to work in many professions such as doctors and lawyers and are mainly excluded from the polis, society with its accompanying rights and guarantees. Hence, by extension, the Palestinian refugees living in Lebanon can be regarded collectively as the homo sacer.

1.14 Limitations of using socio-documentary photography

Cognizant of the fact that socio-documentary photography as a practice will present its own set of aesthetic, political and ethical issues, a critical analysis concerning the relationship between ethics and aesthetics in the representation of refugees through this genre will be discussed as follows

As Alfredo Cramerotti $(2009,30)$ states, "The documentary format itself... does not reflect any given truth... it rather constructs one." This construction of truth refers to how documentary photography can function as a tool of mediation and communication. 
The photographer can act as a conduit to channel her/his personal vision of pertinent issues visually to the wider public, to create awareness. Subjectivity is thus inevitable in the process, however, in order to maintain impartiality in the documentation of the subjects, a photographer should constantly be vigilant and exercise self-reflexivity to check if bias has been involved in the process. This view is reinforced by the NPPA $(2016,1)$ Code of Ethics point 3, "Be complete and provide context when photographing or recording subjects. Avoid stereotyping individuals and groups. Recognize and work to avoid presenting one's own biases in the work."

On the other hand, Howard Chapnick $(1994,338)$ argues otherwise. In the case of documenting Shatila Camp where the main aim is to highlight the living conditions, "subjectivity practiced in the name of necessary social and political change should not be condemned." If a photographer's intention is to advocate for change, there could be a tendency to frame and focus on certain elements of the issues, in order to create an awareness that fits in with her/his agenda.

As subjectivity is an inevitable element which occurs in the process of sociodocumentary photography, it is worth exploring the idea of 'personal vision.' Take for instance, four photojournalists who were dispatched to cover the 9/11 attack on the World Trade Center in New York City, at the end of the day, it is interesting to see the differences in their final artistic output (figures 1-4). This happened as a result of each individual photographer applying her/his own distinct aesthetic vision on how an image or story should be interpreted, framed and told. In fact, the often varied and multi-faceted outcome is not only inevitable as photographers come from diverse socio-cultural and educational backgrounds, upbringing and perception. These should be welcomed and encouraged as a challenge to break the oft-repeated and deeply ingrained stereotypes. 


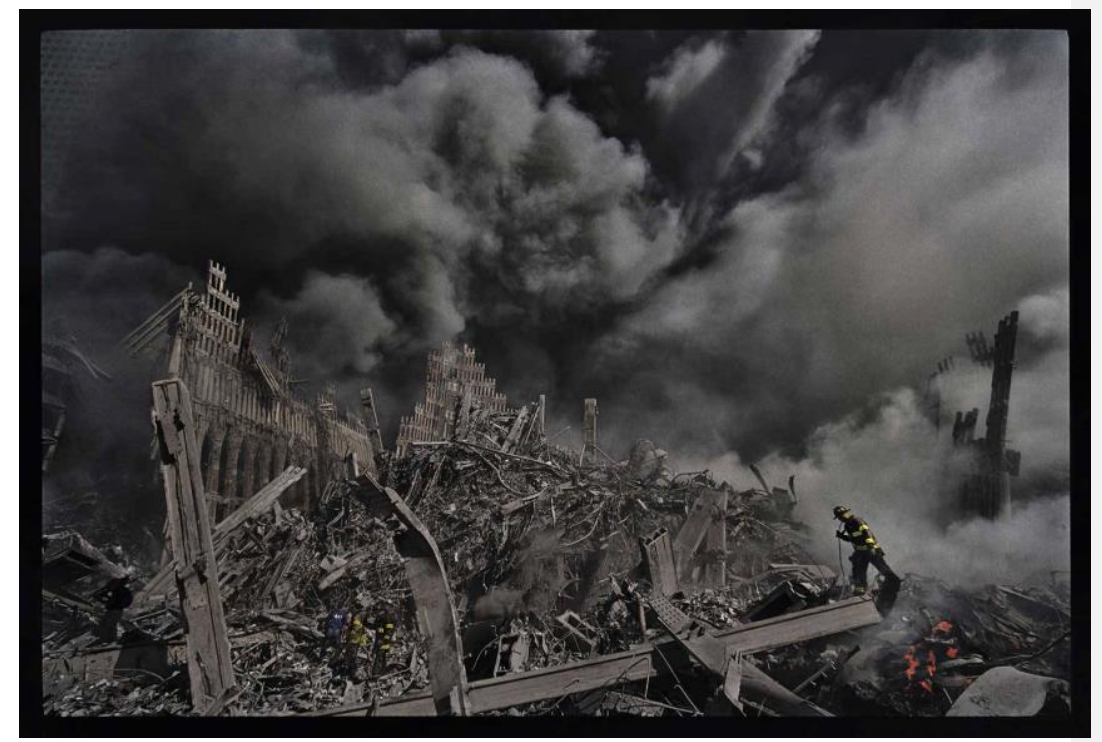

Figure 1. James Nachtwey, 2011.

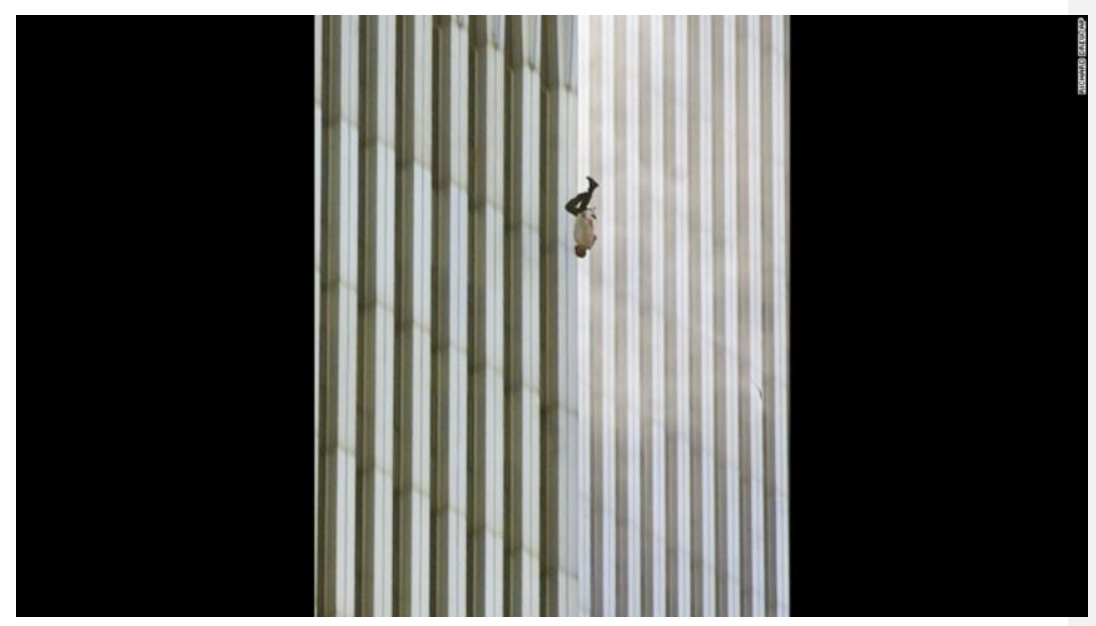

Figure 2. Richard Drew, 2011. 


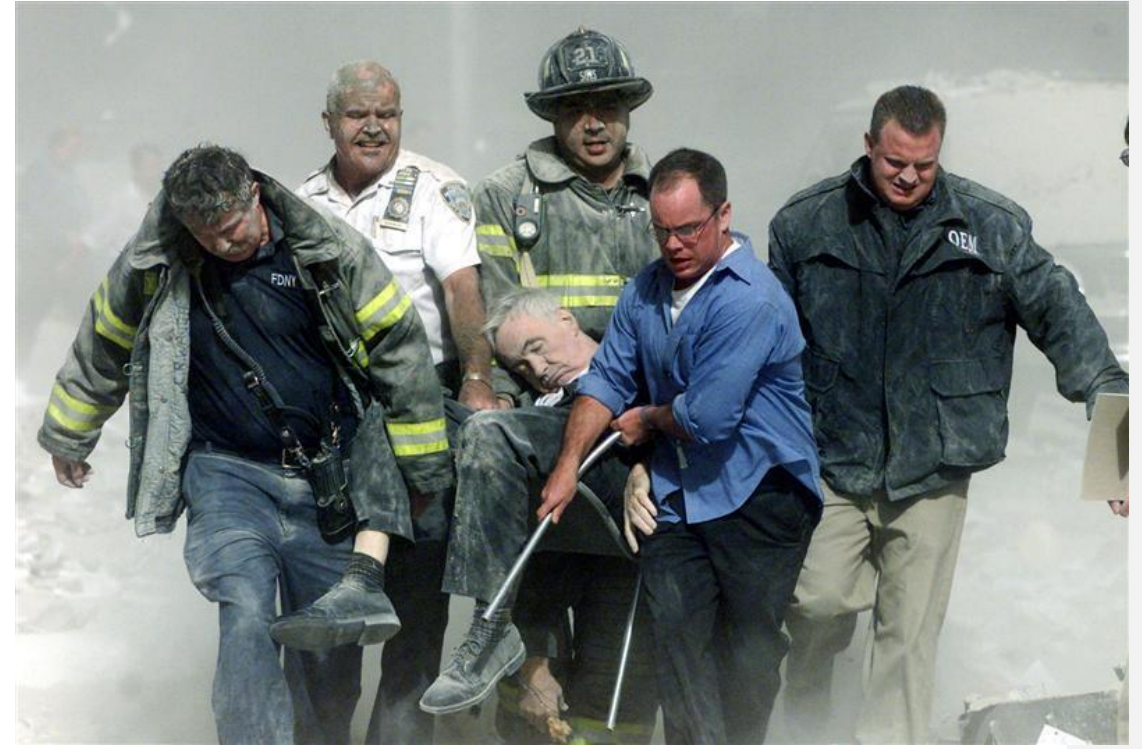

Figure 3. Shannon Stapleton, 2011.

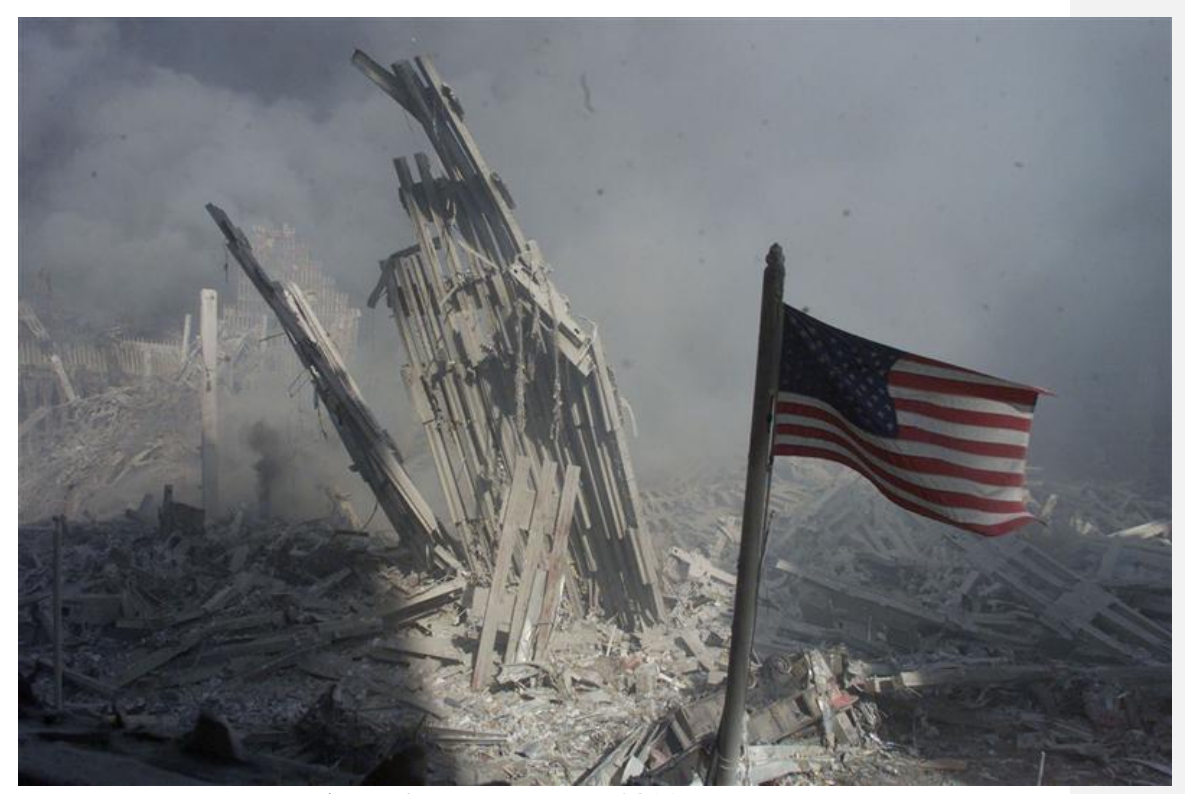

Figure 4. Peter Morgan, 2011.

The notion of harnessing personal vision is further explored by Fred Ritchin who wrote in June 1989 that about eighty European photographers signed a Manifesto in 
Defence of Personalised Photography. Amongst those who signed the manifesto were photographic heavyweights such as Henri Cartier-Bresson, William Klein, Marc Riboud and Jeanloup Sieff. In this manifesto, they voiced their opinions concerning how in recent times, personal vision in the acts of photographing and editing should not be suppressed but be given room to flourish and enhance factual documentation. Especially for editing, the photographer should be given more or complete control over the selection and sequencing of the images in order to construct the photo-series from the personal point of view of the auteur photographer (Ritchin 2013, 99-100). In this vein, a photojournalist with an opinion to articulate can advance causes in meaningful ways as intended. According to photo historian Beaumont Newhall (1982, 133), "the importance of these photographs lies in their power not only to inform, but to move us. They are at once interpretations and records."

Along with subjectivity and personal vision, which are inevitably infused in images produced, emotions too play a significant part in shaping the final image since the camera is wielded by human beings and not robots. The premise that a photograph is the product of a passive recording of subjects, devoid of emotions no longer holds sway as it is assuaged by personal viewpoints as supported by Gross's $(1988,20)$ view that “a work of art is a bit of nature seen through a temperament." Moreover, at the heart of it all, photography is still a form of artistic expression. Social documentarians infuse their practice with their personal vision or style while using it as an investigative tool to probe into socio-cultural and political issues. The role of a photographer is interpretative; hence the integrity of a photographer is paramount in presenting the truth while trying to fulfil her/his stylistic ambitions. 


\section{Chapter 2}

2.1 Introduction to the tropes of Orientalism

In this chapter, the seminal works of painters and photographers from the early $19^{\text {th }}$ century to contemporary times will be examined. It is imperative to gain a deeper understanding of Orientalism's influence on past works of visual arts and trace its lineage of influence through to contemporary artistic and photojournalistic works related to the Middle East in general. The analyses of visual artworks from the past will lead to an examination of how Shatila has been portrayed by various photo agencies such as Magnum Photos, Associated Press (AP), European Pressphoto Agency (EPA) and Reuters Pictures. After establishing the historical context, the final step is to examine how one can represent the Shatila Refugee Camp and its residents visually in the most ethically viable way possible.

As Edward Said (1979, 21) explained, "If the Orient could represent itself, it would; since it cannot, the representation does the job, for the West, and faute de mieux, for the poor Orient." Hence, the West is perceived to be superior to the Orient, thus it warranted works of literature, scholarly studies, paintings and photographs in order to fathom its obscure and chaotic depths. All these efforts to make sense of the 'exotic otherness' of the Orient served as a contrast by which the West distinguishes and defines itself. By extension, one can view the Oriental as representing the other through which the Occident differentiates and reaffirms themselves as the included or sovereign. Therefore, this concept played a part in justifying the colonisation of the Orient by the West, in order to govern and regulate the incomprehensible and exotic other, who is "irrational, depraved (fallen), childlike, different" (Said 1979, 40).

Specifically, of relevance to this paper is the discourse on how the Orient has been portrayed visually from the early $19^{\text {th }}$ century right through to contemporary times. As 
stated by Sardar $(1999,107)$, "Orientalism is very much alive in contemporary cultural practice. All of its main tropes have been seamlessly integrated into modernity. While it is not a monolithic discourse, Orientalism does demonstrate a consistent character throughout history." From literary works to paintings and early photographic works of the $19^{\text {th }}$ century, the contemporary visual portrayal of the Orient has been influenced by and inherited some elements of Orientalism.

A few selected paintings and photographs will be analysed, in order to discover the recurrent strains of Orientalism as it reinvents and readapts itself over the span of about two centuries, thus reinforcing the idea of how Orientalism was "fully formalized into a repeatedly produced copy of itself"' (Said 1979, 197).

2.2 An Orientalist view of the Middle East through early $19^{\text {th }}$ century paintings

From literary works to visual art, the Orient has been depicted as an exotic, chaotic and untameable region (Said 1979, 300). A review of the paintings and photographs below will be used to substantiate and illustrate Said's points as we unveil visual tropes that expose and reflect the Orientalists' vision.

In figure 5, which shows a scene at a souk (Arabic for market), the general impression one gets is that of a backward and chaotic place that falls short of the Western standard of progress and orderliness. Moreover, in relation to the Occident, the sight of the Orientals placing their wares and plying their trades on the ground as animals roam around hints at customs and lifestyles that may be regarded as uncivilised. Even though the painting exudes exoticism, the ancient buildings, veiled women, men in traditional costumes riding camels and donkeys, and run-down tents of the caravanserai suggest a lack of development when calibrated against Western benchmarks of progress. 


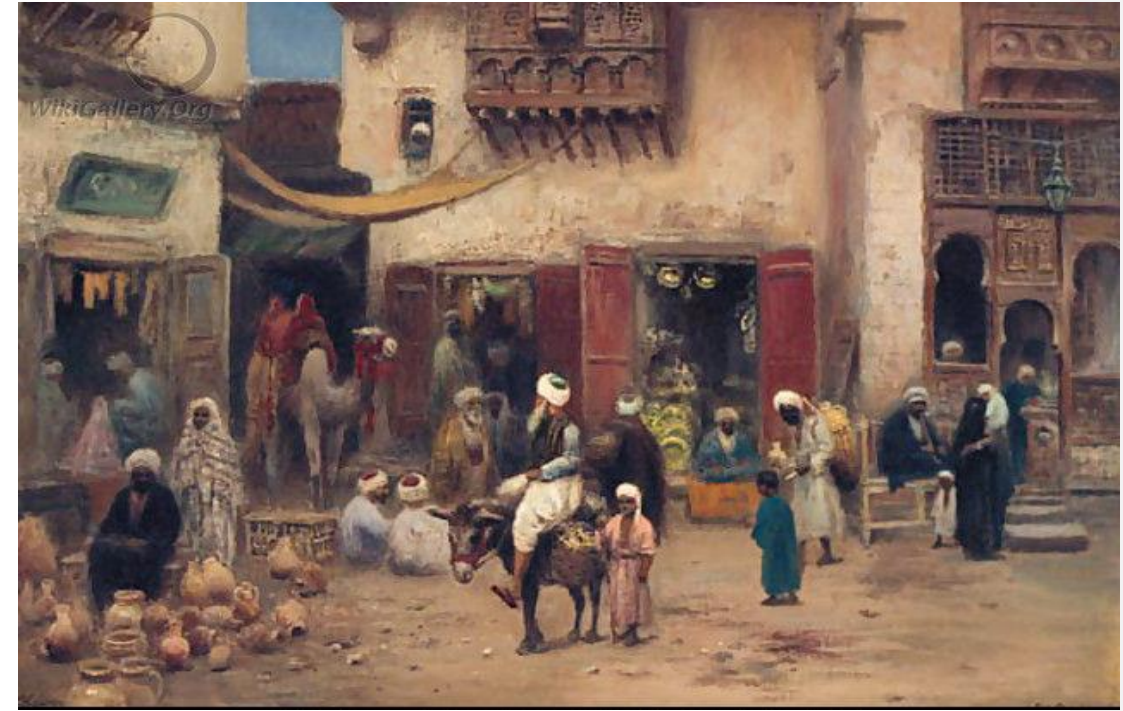

Figure 5. Frans Wilhem Odelmark, In the Souk, 1898

The painting by Jean-Léon Gerôme (figure 6) is a classic example of the mysterious and unfathomably sensuous characteristics as embodied by the Orient. This is why it was used as the front cover for Edward Said's book Orientalism. Set in a hall with blue tiled walls covered with Arabic calligraphy, the centre of attention is directed at a prepubescent boy who is naked except for the python which coils around his upper body. This snake charmer entertains a roomful of older men clad in traditional garb, carrying weapons and musical instruments. There is a strong undercurrent of exotic sensuality as the python could be regarded as a phallic symbol which lures one to associate the Orient with the bizarre and irrational. As Gerôme has never actually journeyed to the Orient, this image reconfirms and reinforces pre-established concoctions of that region in the minds of the Occident. 


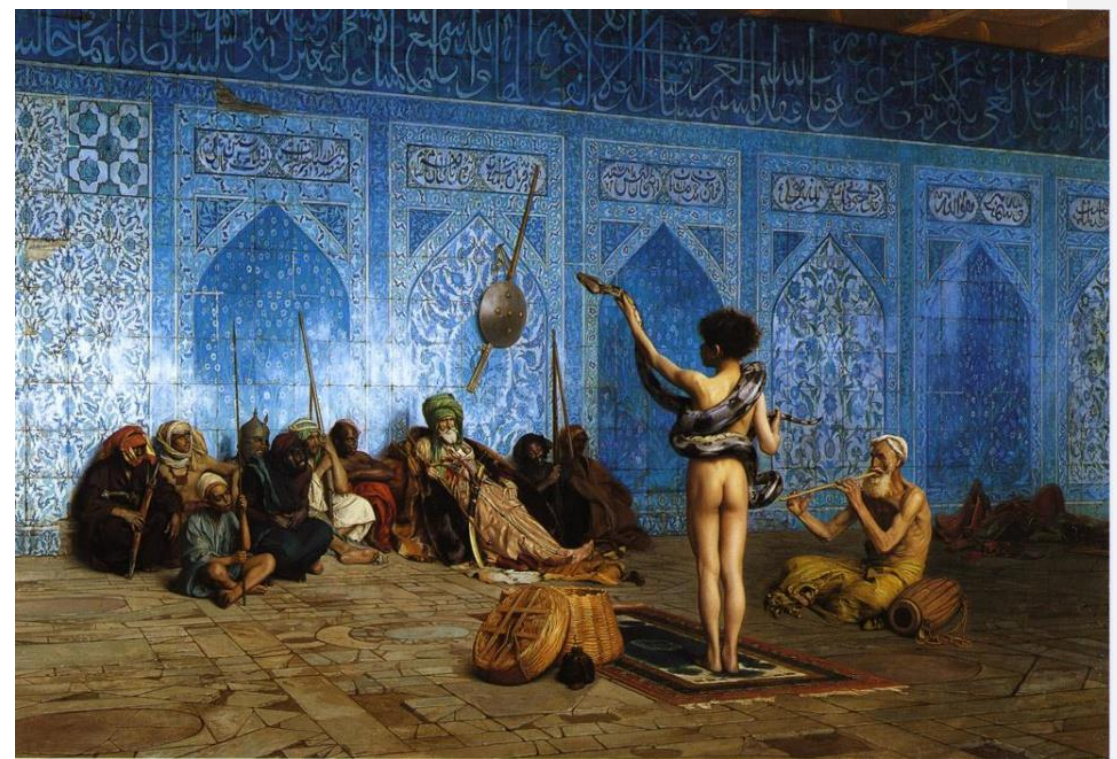

Figure 6. Jean-Léon Gérôme, Le Charmeur de Serpent, 1880, The Sterling and Francine Clark Art Institute

2.3 An Orientalist view of the Middle East through contemporary photography

After examining paintings steeped in Oriental flavour, it is vital to examine how the legacy of Orientalism has seeped into the medium of photography from the early nineteenth century to the contemporary period. Over the span of the last two centuries or so, the West has held hegemony over the visual representation of the developing world. “The Westerner's privilege; because his was the stronger culture, he could penetrate, he could wrestle with, he could give shape and meaning to the great Asiatic mystery, as Disraeli once called it" (quoted in Said 1979, 44).

Prominent news and photo agencies such as Thomson Reuters, British Broadcasting Corporation (BBC), Cable News Network (CNN), Sky News, Agence France Presse (AFP), Associated Press (AP) and European Pressphoto Agency (EPA), are all based in the developed countries. In general, photographs taken by either Westerners or local photographers are sent back to the assigning agencies, from there 
they are subjected to editorial decisions made by someone higher up the news-making hierarchy. The editors could be influenced by her/his cultural background in the process of editing. Thus, the modern-day Oriental is still represented within similar dominating frameworks. This was posited by Edward Said $(1979,26)$ who stated that, "one aspect of the electronic, postmodern world is that there has been a reinforcement of the stereotypes by which the Orient is viewed. Television, the films and all the media's resources have forced information into more and more standardized moulds.”

Through film and photography, "the Arabs are often shown as masses of people devoid of any individuality, soul or personality. Instead, these masses of people are often symbols of rage, suffering, irrational violence and hysteria" (Said 1979, 287). The following images (figures 7-10) show and reinforce some of the Orientalist traits.

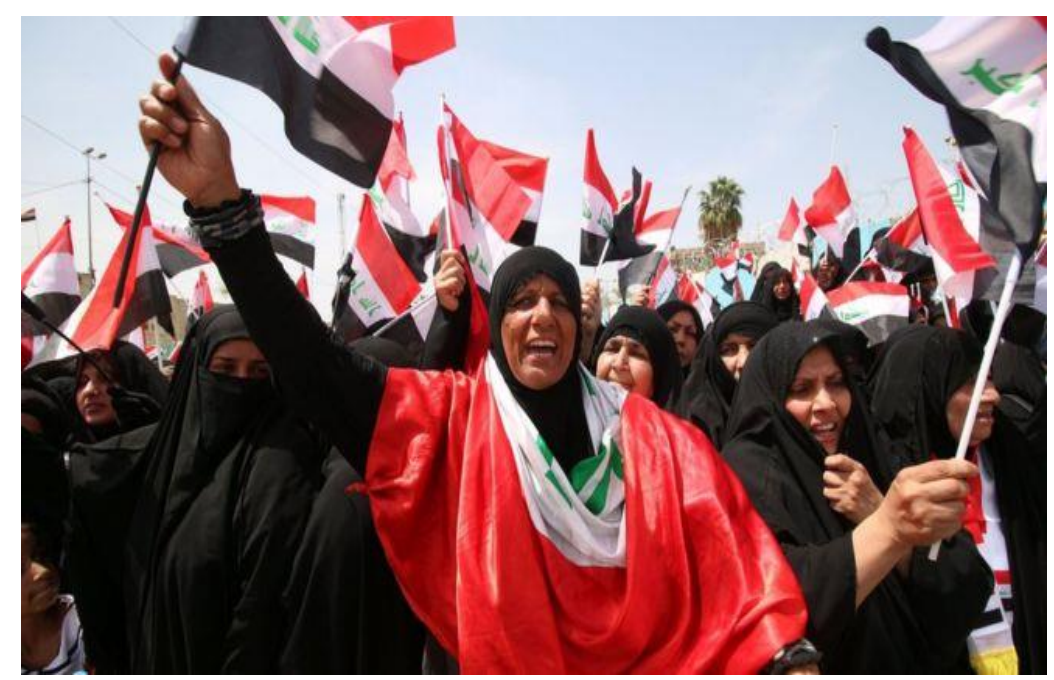

Figure 7. Agence France-Presse, Supporters of the Shia cleric Moqtada al-Sadr marched towards the Green Zone, where the government is based, Iraq, 2016. 


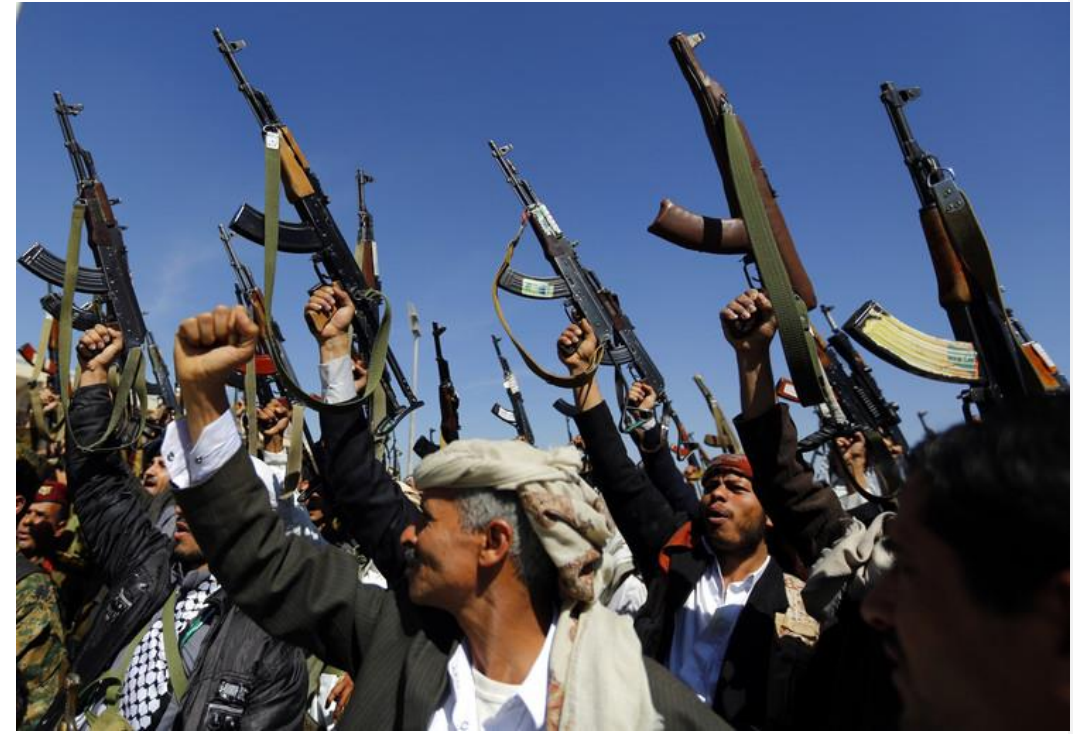

Figure 8. Yahya Arhab, Tribesmen gather to support Yemen's Shia Houthi rebels, 2015

As reflected in the photographs shown, Orientals are basically reduced to negative abstractions personifying traits of violence, irrationality and chaos. By personifying the Oriental and reducing them to "attitudes, trends and statistics," (Said 1979, 291) it is tantamount to dehumanizing them. And again, this confirms the West's way of manifesting its supremacy over the Orient and re-subjugating them. 


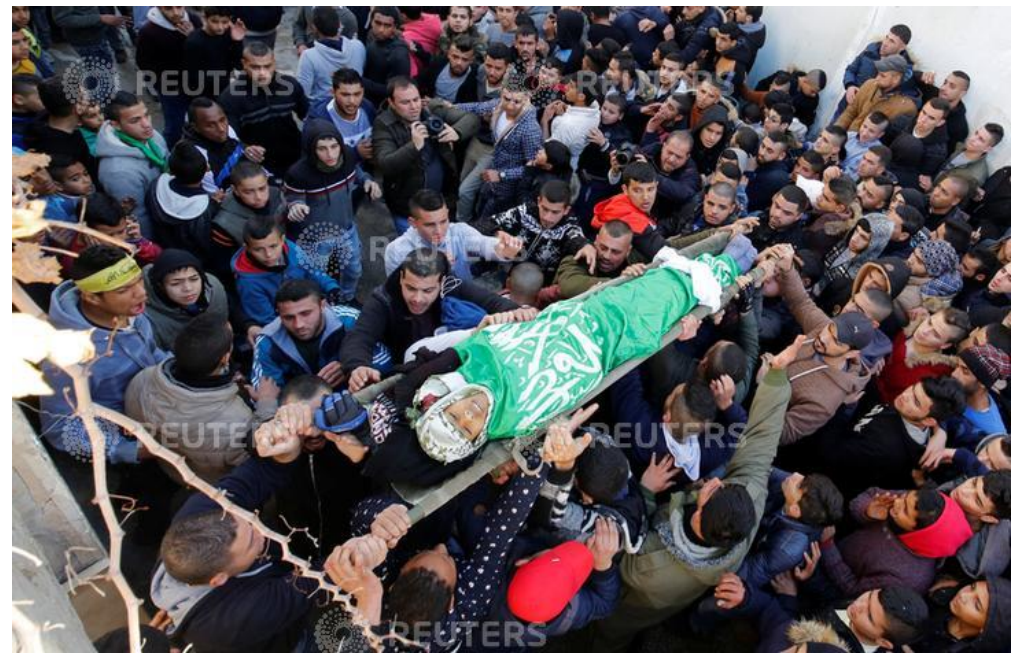

Figure 9. Abed Omar Qusini, Jenin Refugee Camp, the West Bank, 2017

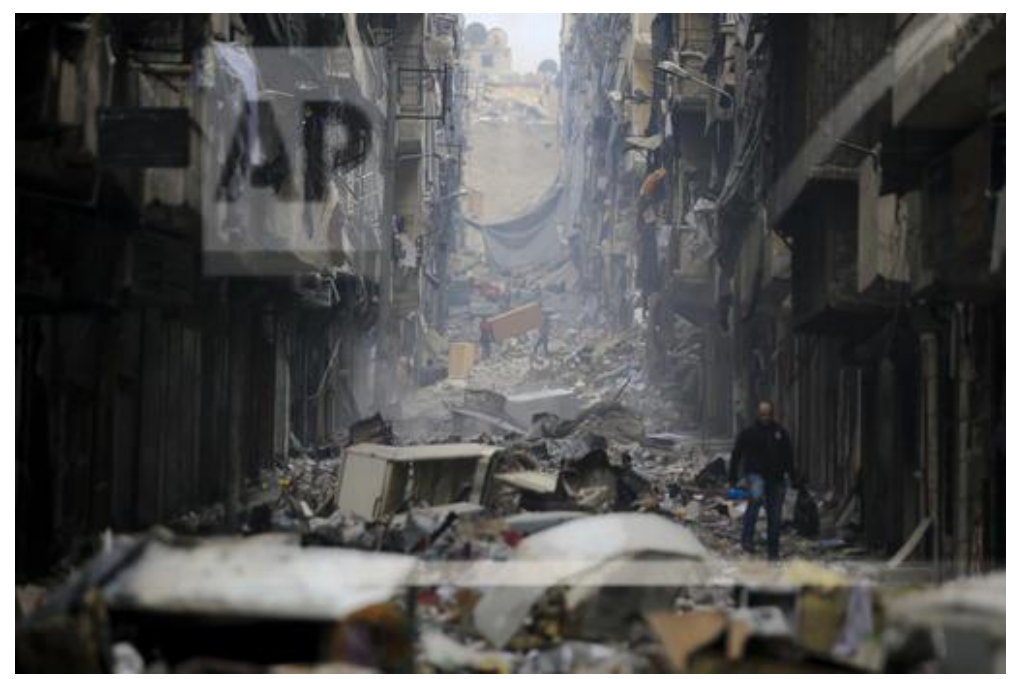

Figure 10. Hassan Ammar, Salaheddine, Aleppo, Syria, 2017

\subsection{Photographic representation of refugees in the media}

First of all, it is important to distinguish between the different types of refugees in order to facilitate the discussion to follow. Refugees are categorised as such:

1. Becoming refugees as a result of war and conflict

2. Becoming refugees as a result of natural disasters 
3. Political asylum seekers facing persecution in their home country

4. Economic migrants seeking better opportunities in the host country

Specifically pertaining to the context of this paper, only refugees which fall under the first category will be discussed. The exile of the Palestinian refugees (homo sacer) who were forced to flee their homeland as a result of the Al-Nakba, fits into this category. Due to the fact that the media tends to cover refugee issues in times of crisis, when people are at their most vulnerable, refugees have thus often been depicted as helpless victims waiting for aid with pleading eyes or as masses crammed into an overloaded boat. For NGOs, the rationale for using such images is that they play important roles in garnering donations, by tapping on the sympathy of the public.

On the other hand, a right-wing tabloid such as The Daily Mail in the UK may portray refugees as masses crammed into overloaded boats, about to invade the host countries. The ethical and political implications of how these refugees have been visually framed will be discussed, followed by an analysis of how Shatila's residents and the topography of the camp have often been portrayed by other photographers.

2.5 Portrayal of refugees as threat

Refugees have typically been typecast as either victims or threats to their host nations. The overcrowded boat crammed with refugees, usually from Africa or the Maghreb trying to enter Italy via Lampedusa, or from the Levant trying to enter Greece through Lesbos are the contemporary icons of mass migration. These migrants are usually portrayed as single, young men looking for work by the press and antiimmigration advocates. The image of hundreds of migrants taking the illegal path to reach Europe gives the impression of a 'threat'. In fact, such forms of representation are not new but are heavily influenced by Christian iconography found in religious paintings such as Christ asleep during the Tempest by Eugène Delacroix (figure 11). The aerial 
photograph in figure 12, of a boat crammed full of immigrants taken by Massimo Sestini bears a very close resemblance to Delacroix's painting. It alludes to 'floods' of refugees trying to inundate Europe which is already dealing with its own unemployment and other social issues.

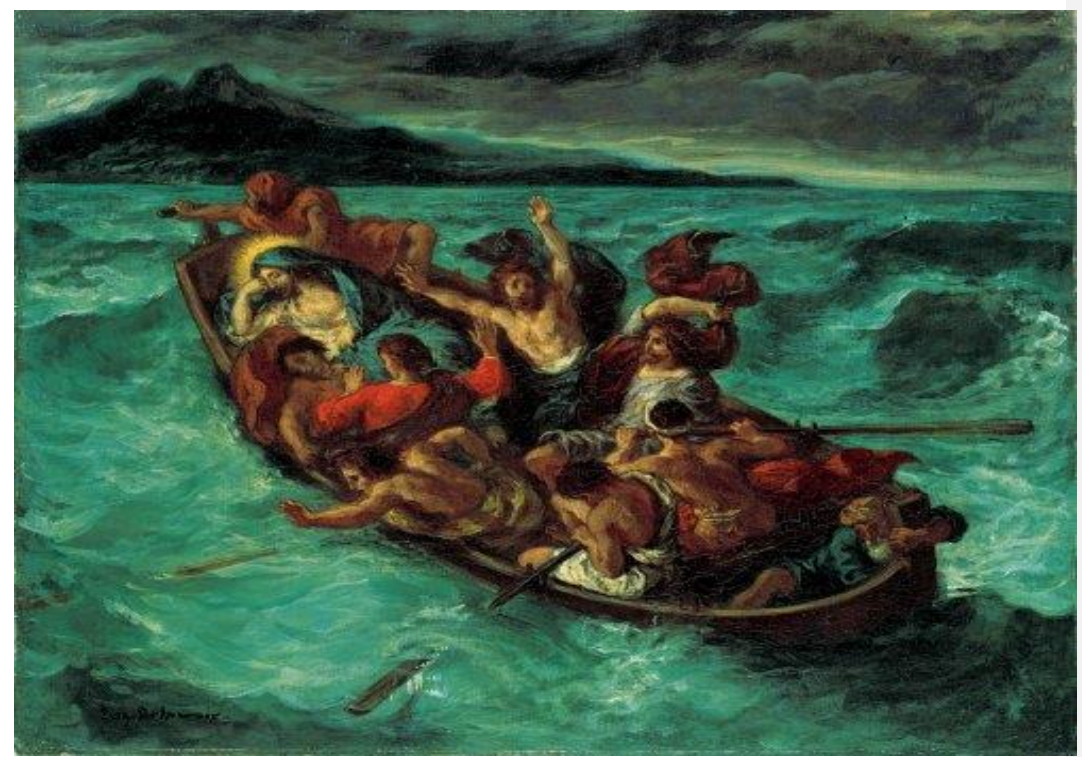

Figure 11. Eugène Delacroix, Christ asleep during the Tempest, 1853, H. O. Havemeyer Collection, Bequest of Mrs. H. O. Havemeyer, 1929

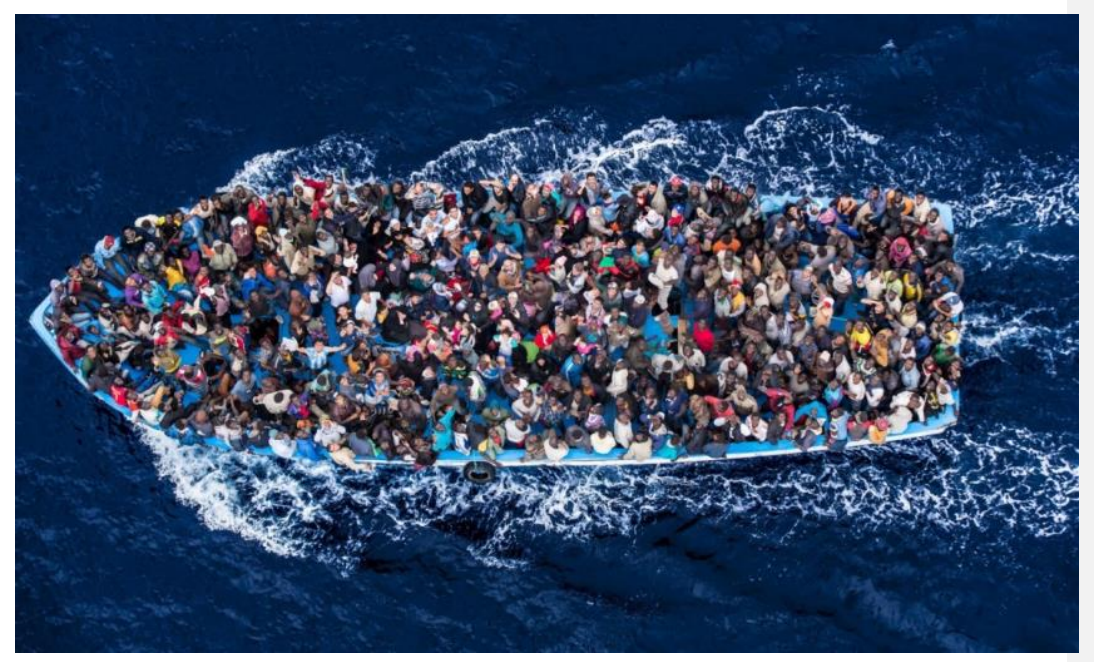

Figure 12. Massimo Sestini, Rescue Operation, 2014 
Although some countries in the EU such as Germany and Sweden displayed more positivity towards hosting refugees, there are politicians such as Viktor Orban (Hungary), Nigel Farage (UK) and Jean Marie Le Pen (France) who have argued otherwise. István Pogány wrote in Social Europe, where he quotes Orban in an interview on Spanish television in which he contended that "further large-scale immigration by non-European elements would mean that all the pillars of the European way of life - freedom of speech and religion, equality before the law and gender equality - may be called into question” (Pogány, 2015). This 'tide' of refugees signifies the gulf between 'us and them' and hints at the challenge of easing their integration within European society at large.

Moreover, the production and dissemination of images of masses of 'faceless' (figure 12) refugees also implies a disinclination to recognise their individuality, hence denying them of an identity and further distancing them from the rest of society. This is akin to turning them into homo sacers which can also create a dehumanising effect, further reinforcing the stereotypical representation of refugees. As the photographer is largely responsible for framing refugees visually, he holds a power over them.

Can the ethical implications of such portrayals be solved by giving a face to the 'sea of refugees'? Figure 13 is an image of Aylan Kurdi's lifeless body on a beach in Turkey. This image became viral and eventually became a symbol for the desperation of refugees trying to enter Europe in the summer of 2015. As part of a collective tragedy, it is not only the individuality of his desolation and helplessness that engulfs us. Even though his face is not visible, he was identified and his background traced whereas the seas of refugees were not. Perhaps, it is far easier to think about nameless, abstract millions than to consider the catastrophe that has befallen Aylan Kurdi. But the fact that he is a child and his lifeless body has been given an identity, highlights the pathos of the refugees' desperation to reach Europe. 


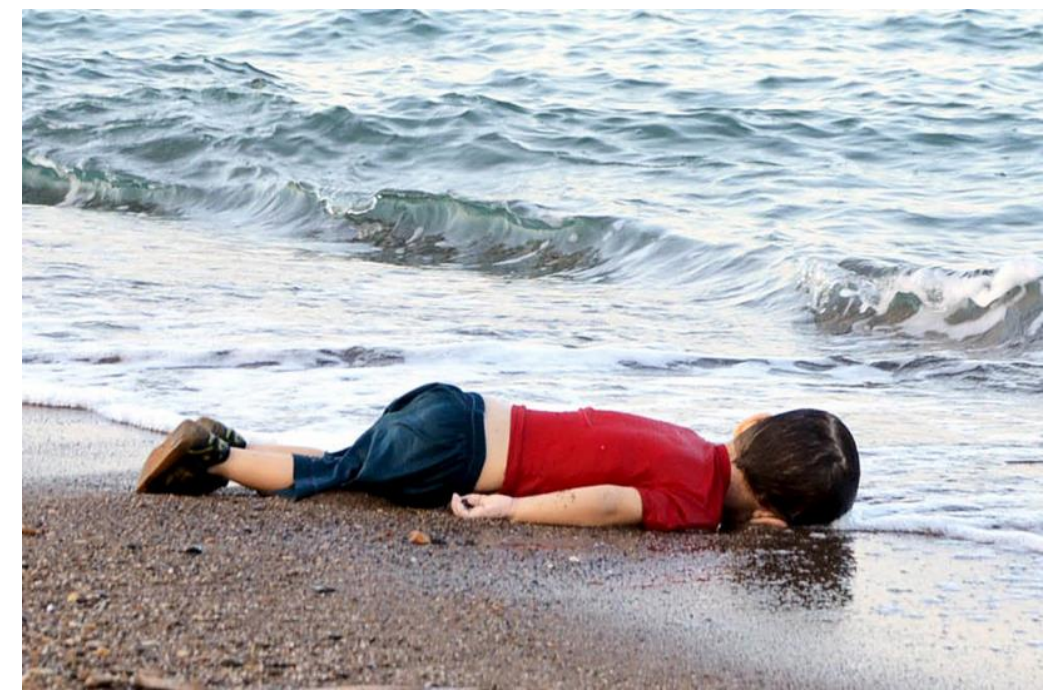

Figure 13. Niloufar Demir, Lifeless body of Aylan Kurdi, 2015

2.6 Images of refugees as victims

The image of starving children with distended bellies, flies in their eyes or skeletal bodies have been used to solicit donations by NGOs. Such portrayal of refugees as victims can also be damaging because it typecasts them as not being able to take control of their lives and that outside administered aid is needed. In figure 14, the image titled 'Hunger' was originally accompanied by the caption, “Guidi Oumarou, 19, a refugee from Central African Republic, sits on a bed at Gore hospital in eastern Chad, where her two-year-old son is being treated for acute malnutrition. Lack of funding has forced the World Food Programme to cut aid to refugees here by 60 per cent.” Here we can see how the victim's situation is directly used as an appeal for funding by an NGO. To further extend this argument, Martha Rosler $(1989,321)$ refers to the way in which "documentary photography presents powerless people to a group addressed as powerful." Hence, ethically speaking, this could inadvertently double victimise the refugees, first by the circumstances which resulted in their current situation and then again by the use of their plight as a symbol(s) in visual representation. 


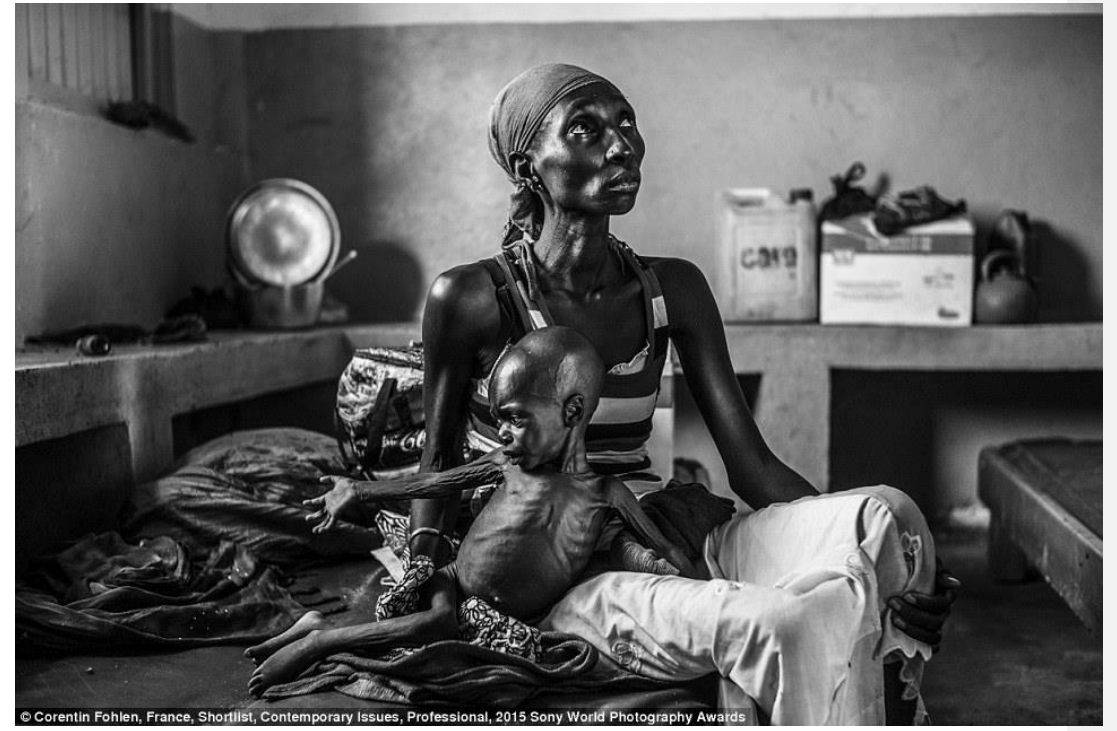

Figure 14. Corentin Fohlen, Hunger, 2015

"Documentary photography thus both takes place within, and reproduces the structure of, the politics of pity" (Szorenyi 2009, 96). This politics of pity is harnessed by NGOs to raise funds through the use of salient images. While the aid money can save lives, and feed the hungry, this double-edged sword can also distance the public from the issue, when they feel good for having 'done something'. The key is to find the best way to represent these vulnerable people with the least moral implications, which will be further discussed in the following chapters.

2.7 Photographic representation of Shatila by other photographers

We will unpick traits of Orientalism that may be manifested in the images of Shatila Camp. The archives of various photo agencies such as Magnum, Panos and Laif as well as wire agencies such as Reuters, EPA and AP are established and credible sources to discover how the camp and its residents had been portrayed over the years. Subsequently, I will compare the images to my own and reflect on how I can make a difference in the portrayal of Shatila. 
From a preliminary research into the archives of the photo agencies mentioned above, most of the photographers who have covered the Shatila Refugee Camp were European. There were a few freelance photojournalists from the Middle East, but none from East or Southeast Asia. All of these photographers were male, by contrast, I am a female photographer from Singapore (Southeast Asia). Coming from a different sociocultural background, I could potentially bring different perspectives to my portrayal of Shatila Camp.

Using the keyword 'Shatila' to search the image archives of the selected photo agencies, the general recurrent visual representations (figures 15 -19) of Shatila are: 1) the dire living conditions, 2) commemorations of the Al Nakba, Al Quds and Land Day, 3) kids playing in narrow lanes lined with garbage or with toy guns, 4) the Sabra-Shatila massacre 5) and mass demonstrations. Almost all the images in the databases of these major photo agencies are shot outside in the lanes and alleys while very few images are taken indoors. The people are often portrayed as masses or large groups usually demonstrating on the streets (figures 15 and 16). There is very little emphasis on individuals who are identified and named. This suggests that the photographers have probably not made more than superficial contact with their subjects. Thus, these images are not ideal in terms of paving the inroad into real camp life which could provide deeper insight into the Shatila Refugee Camp and its residents. 


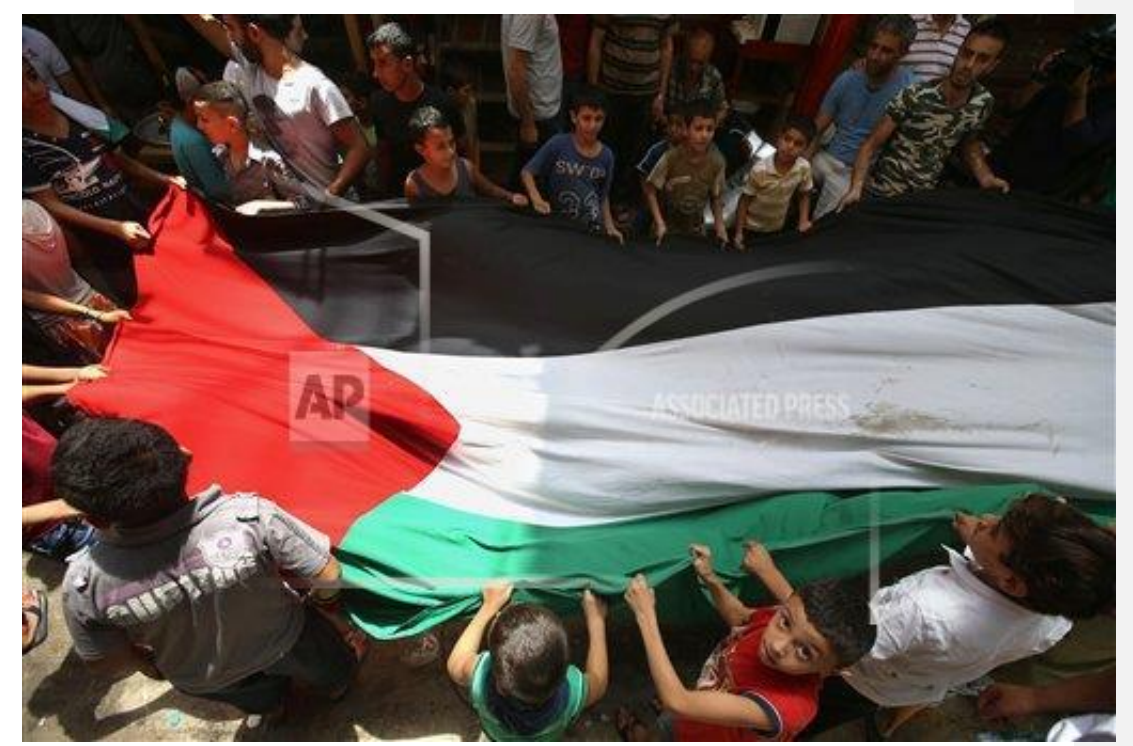

Figure 15. Hussein Malla, Al Quds Day commemoration in Shatila Camp, 2014

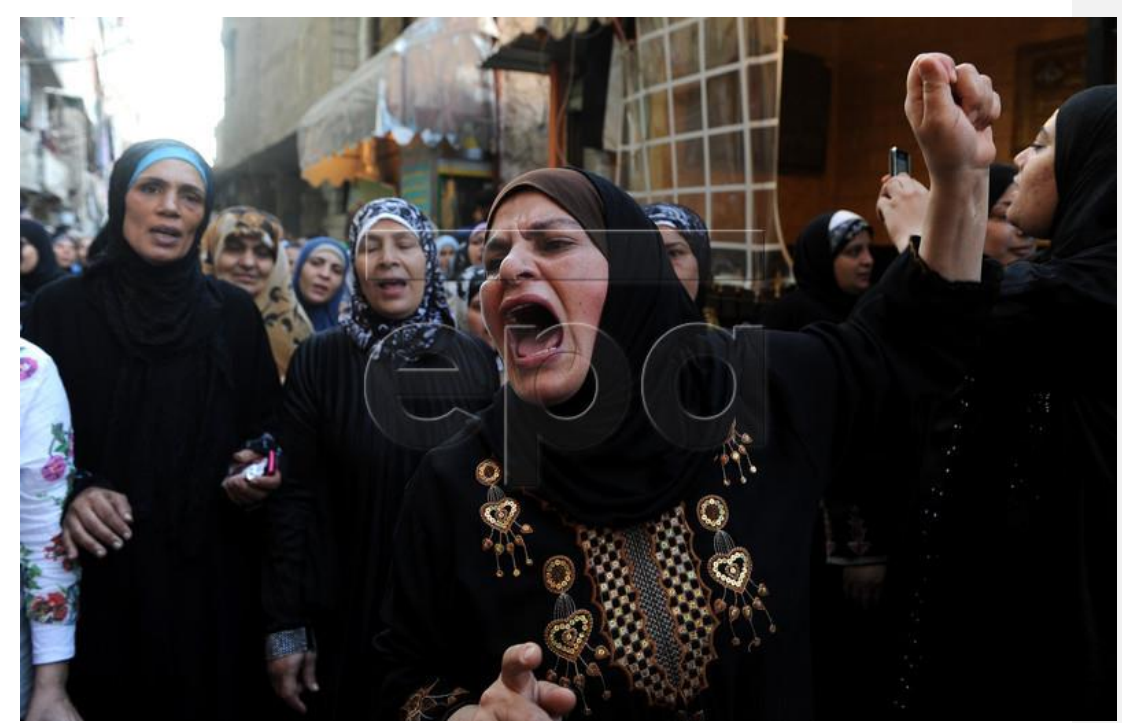

Figure16. Wael Hamzeh, Untitled, 2012 


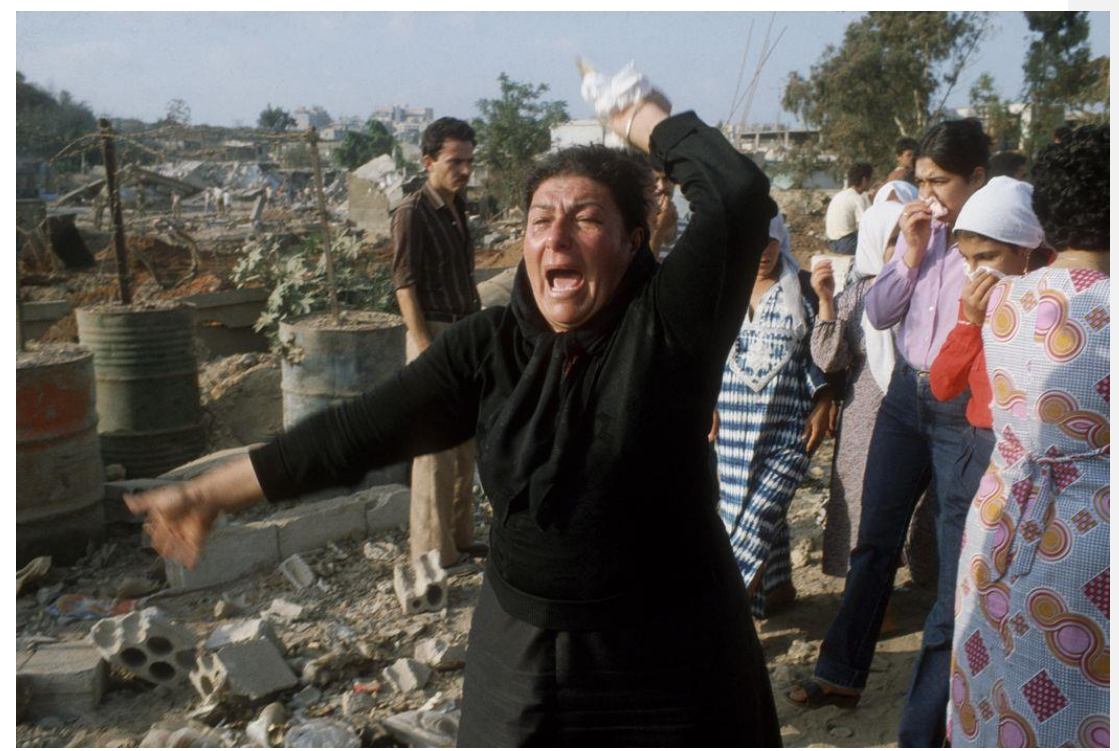

Figure 17. Chris Steel Perkins, Sabra-Shatila Massacre, 1982

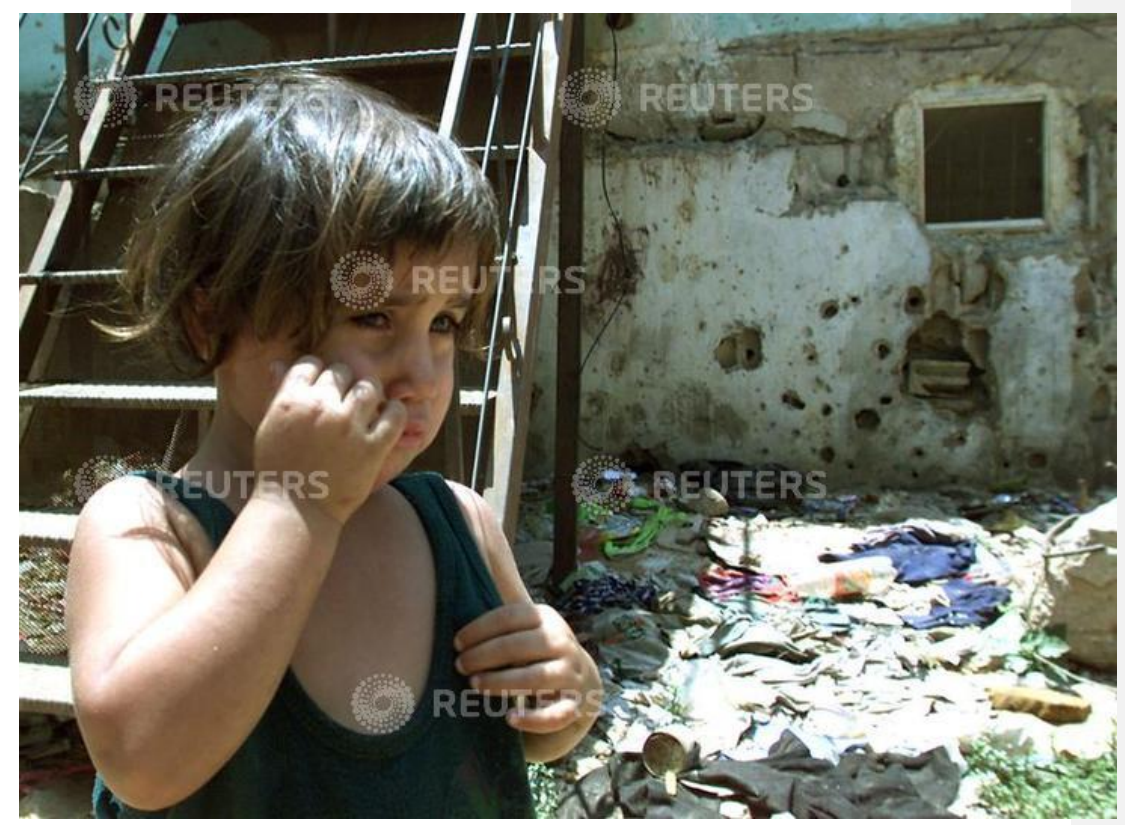

Figure 18. Jamal Saidi, Untitled, 2001 


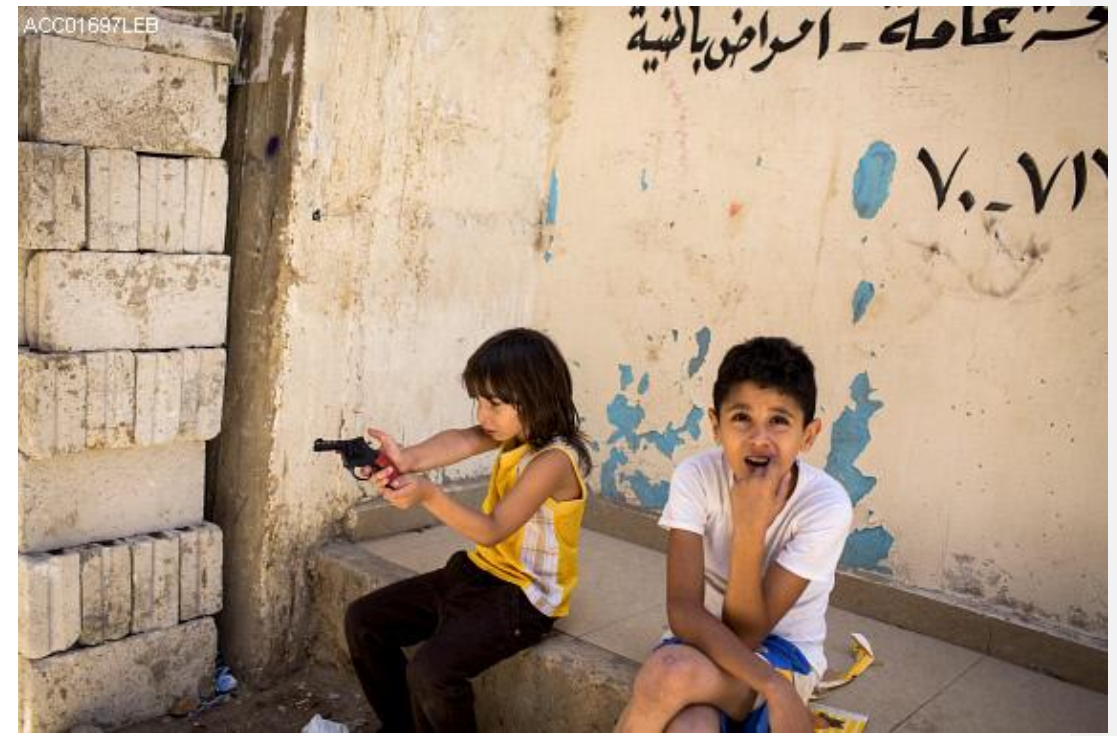

Figure 19. Andrew McConnell, Untitled, 2013

Quite a number of images observed in these databases seem to have been taken by freelancers who tend to be male and of Middle Eastern origins. Based on my personal experience as a freelance photojournalist for 11 years, many assignments have been outsourced to local photographers especially in recent years, due not only to the ease of sending images electronically but also because of cost efficiency.

Before the advent of the internet and the digital revolution, normally Western photojournalists would be dispatched to the Middle East to cover reportage stories. Many of the images available in the archives suggest that trips to the Shatila Refugee Camp were made only when there were major events happening such as the anniversary of the Sabra-Shatila massacre, Land Day, Al Quds Day, Al Nakba Day, the commemoration of the death of Yasser Arafat and the celebration of the founding day of the PLO.

The recurring images of how the residents of Shatila get caught up in one sensational event or tragedy after another could potentially distance the viewers. Such images run the risk of generating the impression that dramatic events normally happen 
to people from the Orient. As mentioned by Said $(1979,291)$, the traits of Orientalism serve to "keep the region and its people conceptually emasculated, reduced to attitudes, trends, statistics: in short, dehumanised.”

With the modern Middle East perennially typecast this way, the vicious cycle repeats itself again. This provides the Occidental saviour with the excuse and pretext to invade, rescue and rectify the chaos which the Orient seems to be constantly mired in. In fact, twenty-five years after the publication of Edward Said's seminal book Orientalism, he wrote a preface to the third edition (2003) in which he raised the question of "whether modern imperialism ever ended, or whether it has continued in the orient since Napoleon's entry into Egypt two centuries ago" (Said 2003, 12). Said went on to elaborate on how the modern-day Orientalists have adopted similar rationales over the "oil and strategic control in the Gulf, Iraq, Syria, Palestine and Afghanistan” (Said 2003, 26). In fact, one can trace the trajectory of how the Orientalists have intervened in the region since the Napoleon's invasion of Egypt through to NATO's R2P (Responsibility to Protect) operation in Libya in 2011. The latter done under the pretext of shielding Libya's civilians from the tyranny of Qaddafi. Therefore, the purportedly more superior West will always find justification for its interference in the modern-day Orient, for as long as each of these "phases and eras produces its own distorted knowledge of the other, each its own reductive images, its own disputatious polemics" (Said 2003, 87).

Moreover, many of the images in the archives carry negative connotations such as poverty, misery, suffering, ruins and chaos, violence and aggression, hysteria and protests, veiled women and under-privileged children which are reminiscent of the features of Orientalism. While one cannot ignore the harsh living conditions of Shatila which ought to be highlighted, the perpetuation of such damaging traits to a community of vulnerable refugees trying to eke out a living in Lebanon could over a period of time 
lead to stereotyping the residents as people who have consigned themselves to their lot. In the words of Larry Gross $(1988,203)$, "eventually, the characteristics may become accepted. The group becomes fair game for more serious slurs, bigotry and prejudice. This will limit our ability to interact responsibly in the world community." Once again, this reinforces the idea of double victimisation as the subaltern or homo sacer becomes first of all, victims of their circumstances and then again as victims of totalisation when they are reduced to mere symbols. Lévinas $(1969,303)$ refers to totalisation as the reductive categorising and typecasting of the subjects whose voices are denied and as a result, it becomes an ethical breach.

Therefore, it is imperative for a photographer who wants to visually represent her/his subjects to spend enough time and immerse oneself in their world, in order to gain a better understanding of a culture and lifestyle different from one's own. This process should help to mitigate the preconceived notions which could sub-consciously colour a photographer's perception of the subjects and in turn be prescribed onto the final images produced.

Due to the fact that tight deadlines had to be met, most of the images found in the archives appear to be cursory in nature and do not seem to reflect an ability and/or desire to delve deeper into the life of Shatila and its residents. However, the photos taken by one male German photojournalist, Jens Schwarz, from Laif Agentur für Photos and Reportagen (figures 20 and 21), broke the convention of how women in the Middle East have often been depicted by using environmental portraiture to illustrate them in their workspace. The oft-repeated image of the helpless, submissive, veiled woman who is subservient to a largely patriarchal society is defied in these two images. The two women (one of them is named Fatima while the other is not named) are portrayed as independent 
and confident. They both appear to be able to exercise agency in their own lives just like their Western female counterparts.

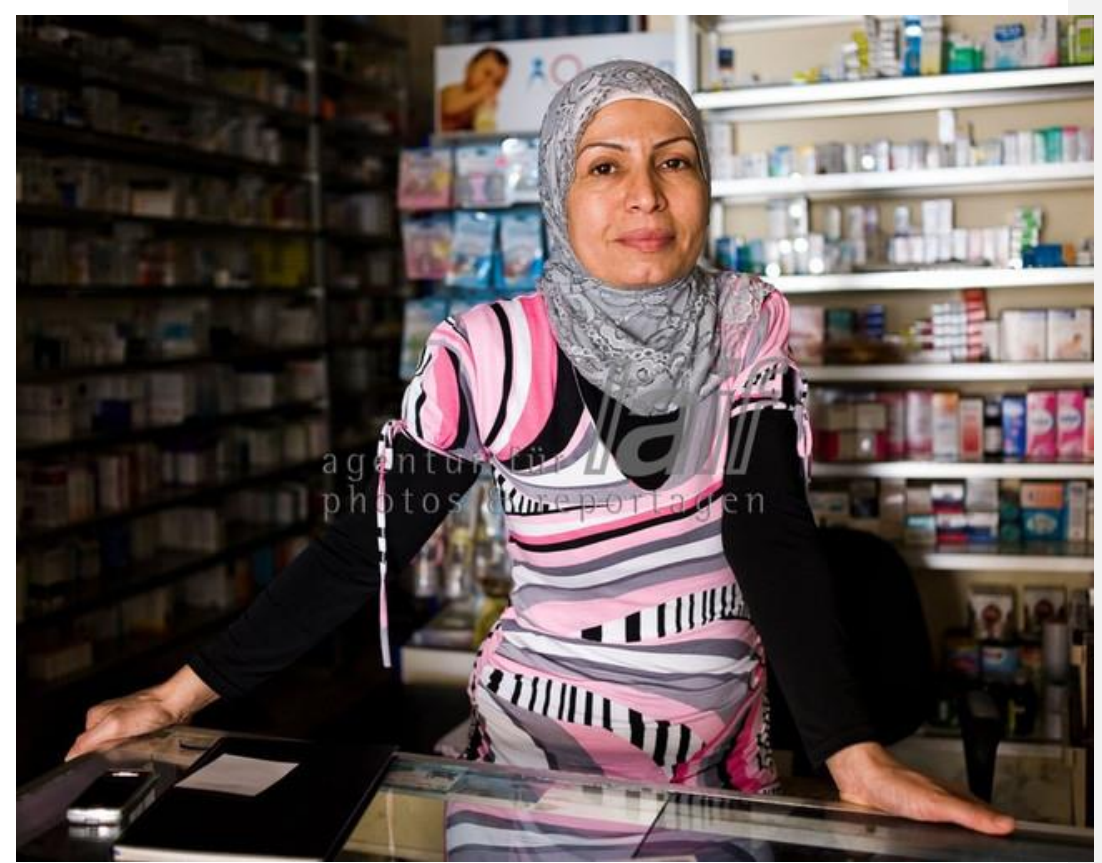

Figure 20. Jens Schwarz, Shatila and Burj el-Barajneh series, 2008. 


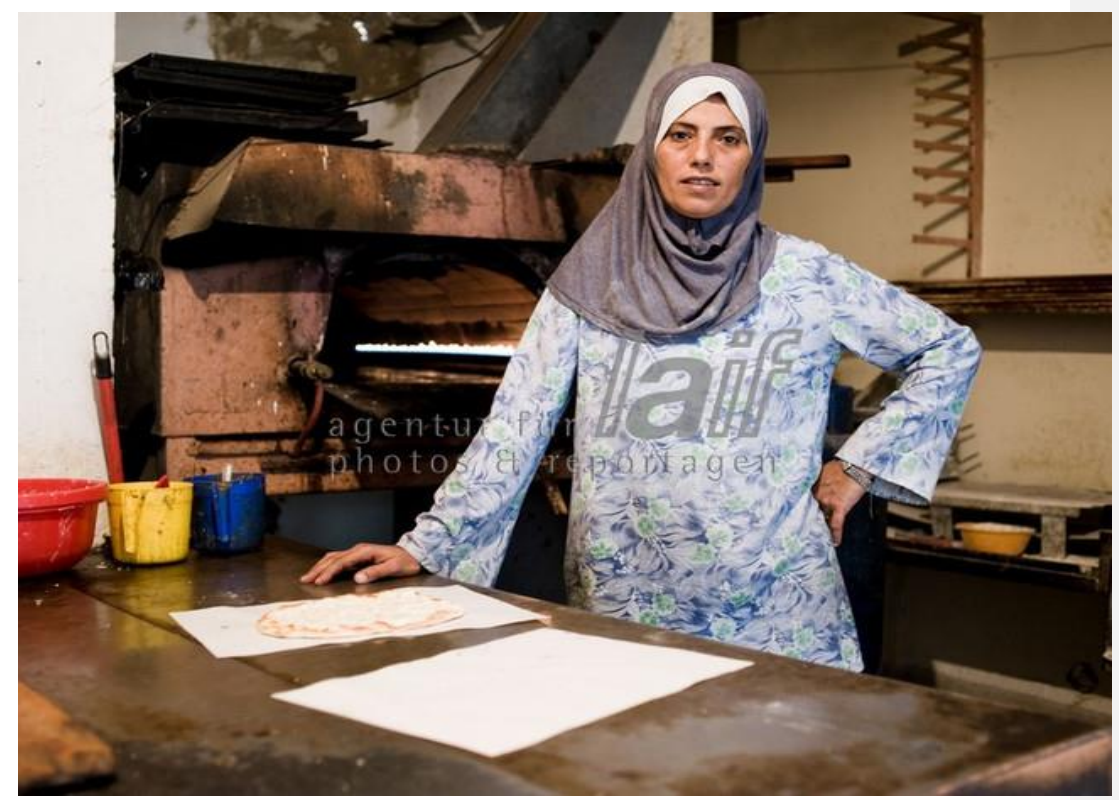

Figure 21. Jens Schwarz, Shatila and Burj el-Barajneh series, 2008

The efforts of a photographer who manages to establish rapport with her/his subjects will be able to imbue their images with an added layer of meaning. In contrast with images taken of people on the streets who are sometimes unaware that they had been photographed, the act of making connections with the subjects opens up another dimension of socio-cultural encounter between the viewers and the subject. Through the representation of the subject's face which becomes highly visible and recognisable, the responsibility of the portrayal of the subject's face must be given the utmost ethical consideration. This is emphasised in Lévinas' $(1985,86)$ Conversation with Phillipp Nemo, in which he says that "the very uprightness of the face, its upright exposure, without defense... is that which stays most naked, most destitute." Hence, the photographer shoulders a heavy responsibility in representing her/his subjects as the unintended consequences in the representation of anyone, not just of the subaltern (who are regarded as vulnerable), could potentially have a drastic impact on a person's life, 
given the extensive level of visibility which the images are exposed to online or in publication. 


\section{Chapter 3}

3.1 The portrayal of Oriental women in $19^{\text {th }}$ century paintings

After considering how Orientalism as a concept has shaped the visual representation of the people from the Orient at large in the previous chapter, the building blocks are now laid for the further analysis of how the Oriental female has been visually portrayed in paintings and photographs. In this study, we will be confining our inquiry only to images of the Middle East. It will be followed by a section on how female refugees from the Orient have often been portrayed. This is essential in establishing the platform for further discussion of the central female subject of my photo project on Shatila, Zeinab (not her real name). As the key figure in my work, Zeinab who was born and raised in the camp for more than five decades is the ideal conduit through which one can discover and empathise with the struggles, psyche and private lives of the camp residents. To add another layer of contrast, some contemporary images of teenage girls taken in Shatila Camp and Beirut, by Rania Matar from the series, A Girl and Her Room, will also be included as part of this discussion

Using the understanding of the outcast or homo sacer from Giorgio Agamben, one can also apply this idea to the Oriental who can be regarded collectively as the homo sacer. Orientals are defined by their exclusion from the seemingly superior Occident. To further expand on Agamben's idea, one can also consider how an Oriental woman can be likened to a homo sacer within the Orient itself as she occupies a liminal position in a predominantly patriarchal background. In Gustave Flaubert's sensuous depictions of the Oriental woman, he projected "most of the Orientalist paradigms by which the Arab femininity was approached, perceived, treated and defined" (Mehdid 1993, 29). This widely influential impression of the Oriental woman was based on Kuchuk Hanem (a courtesan whom Flaubert had met in Egypt). As Said $(1979,6)$ reminds us, in Flaubert's 
depictions of Kuchuk Hanem, "she never spoke of herself, she never represented her emotions, presence, or history. He spoke for and represented her.” Md. Mahmudul Hasan $(2005,31)$ lends further support to this statement, “Already oppressed by local patriarchy, women were represented in a demeaning manner by the Orientalists and thus wore two badges of humiliation: as women and as Orientals."

Linking these observations of the Oriental woman as being silent and subservient to both the local patriarchal dominion and the Orientalist male's depiction of her, Agamben's concept of the homo sacer makes sense. The status of the Oriental woman is reduced to that of a homo sacer (woman) within the homo sacer (Orient). She is thus doubly marginalised by virtue of her gender, as Mehdid (1993, 19) says of the, "manipulative cultural system in which the Arab female has been, perhaps more systematically than the Arab male, dehumanised and disincarnated," and by her existence within the Orient which is both subjugated by and segregated from the dominant Occident.

Specifically pertaining to this thesis, the peripheral position that an Oriental woman occupies will be examined through Western paintings and photography. One of the earliest forms of such visual representation existed in the form of paintings. While some painters such as Jean Auguste Dominique Ingres relied on travellers' tales or literary works such as Flaubert's to construct their imagination of the Orient, other painters such as Eugène Delacroix made their way to the Orient and portrayed what they had witnessed (Nochlin 1989, 51).

Through the analysis of works by Jean-Léon Gérôme and Ingres, we will see how the Oriental women have often been portrayed as sensuous and eroticised beings found in places such as a harem or bathhouse (Pasin 2014, 123). These two $19^{\text {th }}$ century French painters portrayed Oriental women as servile possessions of men, for entertainment as 
well as sexual gratifications. As the harems were forbidden to foreign men, these works are possibly the products of their fantasies of what transpired inside. The unifying factor between the two artists is that their works were not created in a vacuum but were products of their imagination shaped by the prevailing socio-cultural environment, and they might have possibly been inspired by the tradition of the Tales of the Arabian Nights.

Gérôme's painting Slave Market (figure 22) was set in a courtyard with men donned in traditional costumes and turbans as well as veiled women sitting on the ground. The entire scene is saturated with the flavours of the Orient. A young woman has been stripped naked by a slave trader and presented to a group of prospective buyers, who are fully clothed, for examination. An act both disturbing and demeaning was enacted when a prospective buyer probed his fingers into her mouth to check her teeth, presumably to gauge her health. For someone who has never journeyed to the Orient, this painting by Gérôme is strongly redolent of the suppressed desires of the Occidental male.

The impenetrable world of the harem or bathhouse led Ingres, who has never been to the Orient, to resort to using Lady Mary Wortley Montagu's published accounts (Bloom 2004, 17) of her visit to a bathhouse in Turkey to create his famous painting Turkish Bath (figure 23). Through his interpretation, Ingres visualised a bathhouse with heavy sexual overtones that titillates the fantasies of an Occidental male. The harem-like bathhouse is crammed full of naked female bodies lying close together, in highly eroticised poses and gazes which fit perfectly into Flaubert's description of the Oriental woman in his books Herodias and The Temptation of Saint Anthony. 


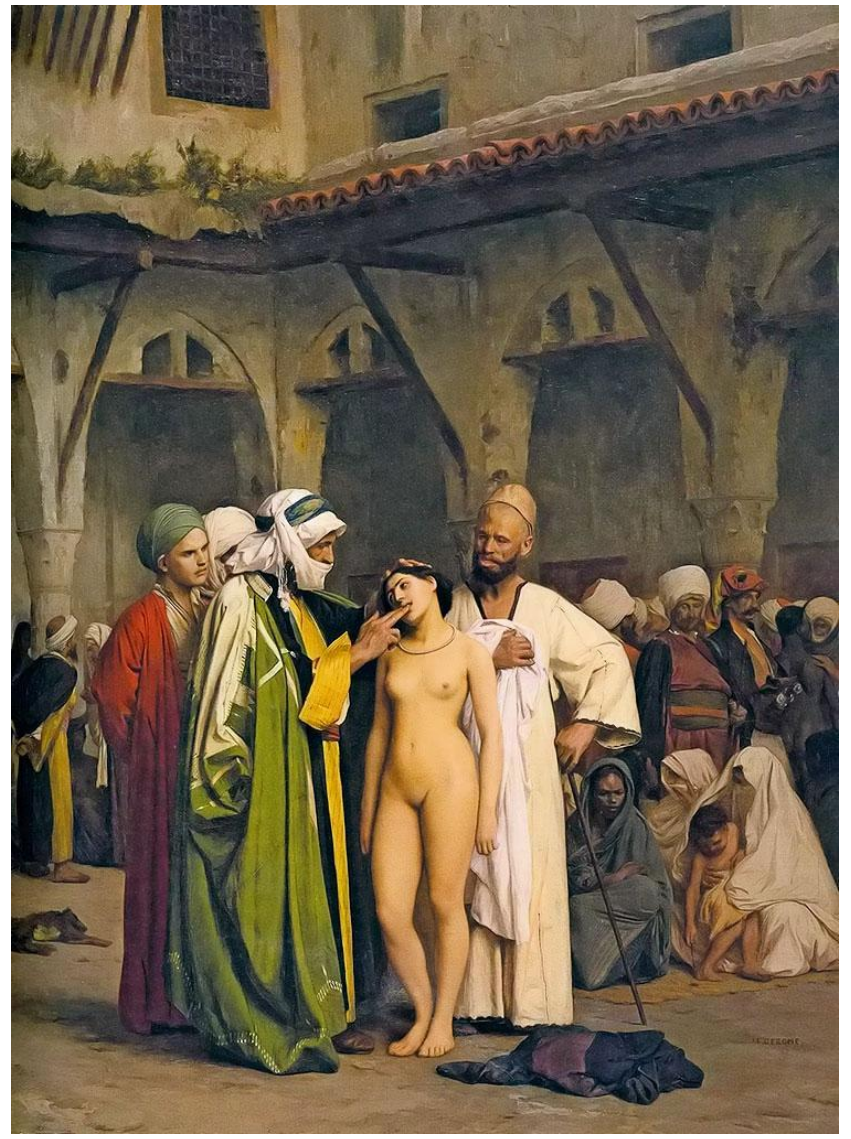

Figure 22. Jean-Léon Gérôme, Slave Market, 1866, Sterling and Francine Clark Collection 


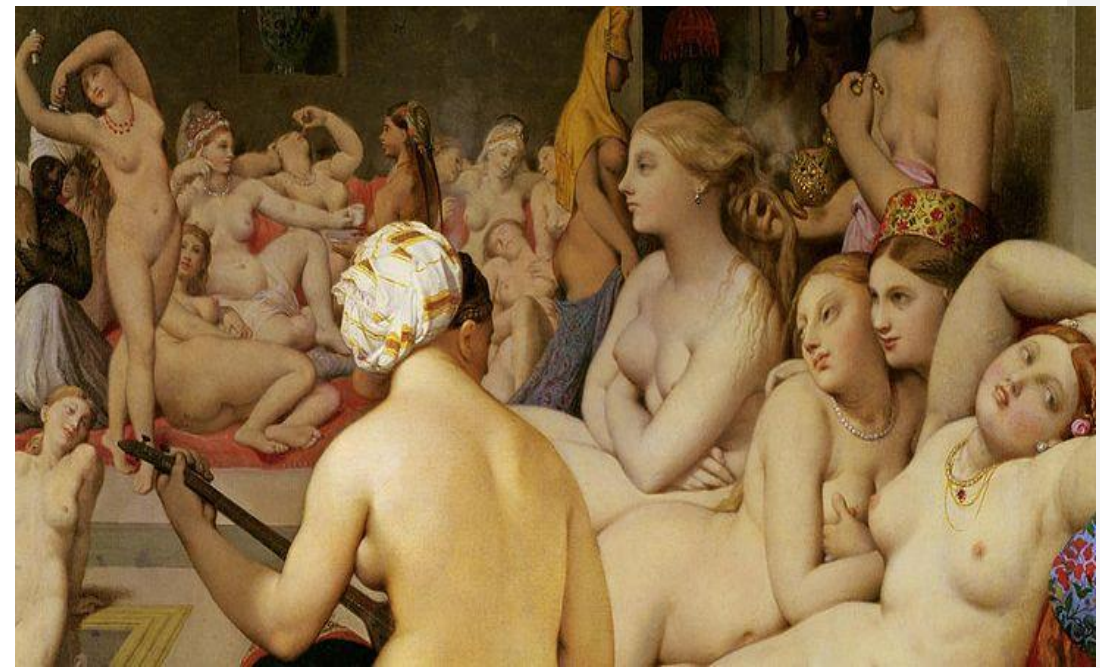

Figure 23. Jean Auguste Dominique Ingres, Turkish Bath, 1862

Perhaps Ingres' best known painting is the Grande Odalisque (figure 24). The concoction of the fictitious, reclining woman with her seductive facial expression and body language hints at Ingres's desire to witness the unknown territory of the Oriental harem in which he never had the chance to set foot in. Hence the sexual objectification of the odalisque could be a way for him to subjugate the mysterious Orient or an extension of his own fantasies regarding the Oriental woman. 


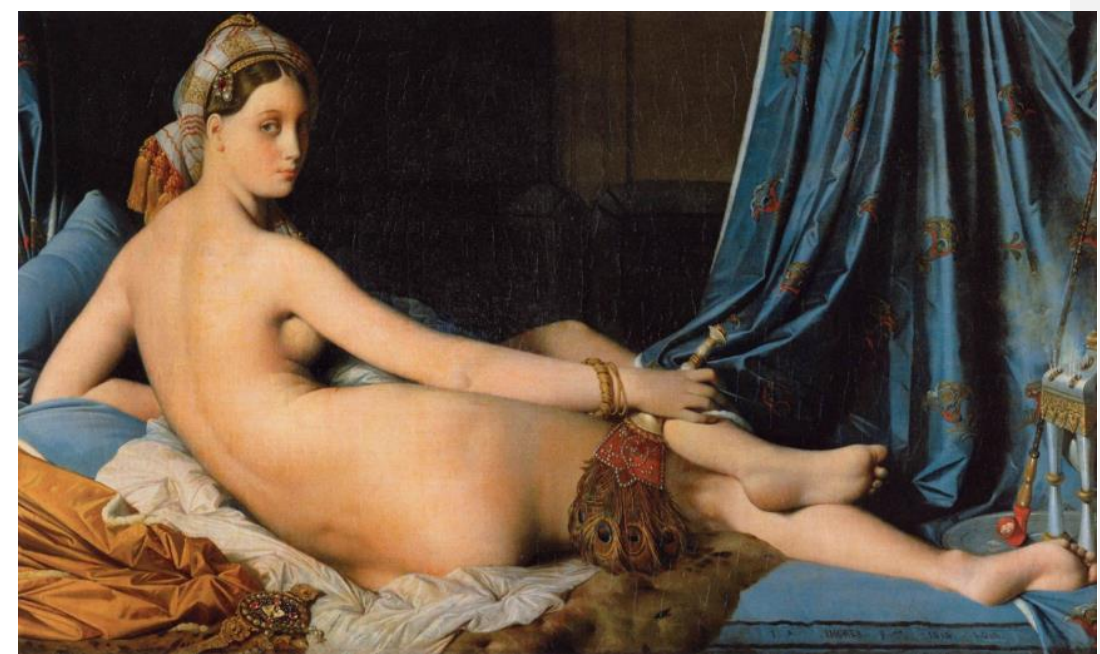

Figure 24. Jean Auguste Dominique Ingres, Grande Odalisque, 1814

Unlike Ingres who had never been to the Orient, Delacroix travelled to the Maghreb in 1832. Hence, the works of Delacroix which should presumably have a better grasp of the reality of the places in the Orient he had visited, will be used for comparison with Ingres'. In fact, Isabella Archer $(2010,71)$ argued that Delacroix‘s paintings took the Occident's "imaginings of the Orient a step further with their authenticating details and rich subject matter." With the help of a colonial administrator, Delacroix managed to gain access to a harem in Algeria (Archer 2010, 71). In contrast to Ingres' portrayal of the harem, the women inside Delacroix's painting (figure 25) were not naked but fully dressed. It is also devoid of the eroticism which exudes from Ingres' works, with none of the alluring expressions on their faces. The activities of the women turned out to be rather mundane, that of having a conversation or resting in one corner, none of which quite fit the image of the seductive Oriental woman found in Ingres' paintings.

In comparing the voyeuristic yet distinct ways that the Orient had been constructed by Gérôme and Ingres, who had never travelled there and Delacroix who had, it highlights how the impressions of the Orient and the Oriental female had been distorted 
by Gérôme and Ingres. And by extension, this phenomenon could be representative of the mindset of those who had never been to the Orient. This hints strongly at how deeply entrenched and distorted the visions of the Orient were to those from the Occident who had never travelled there.

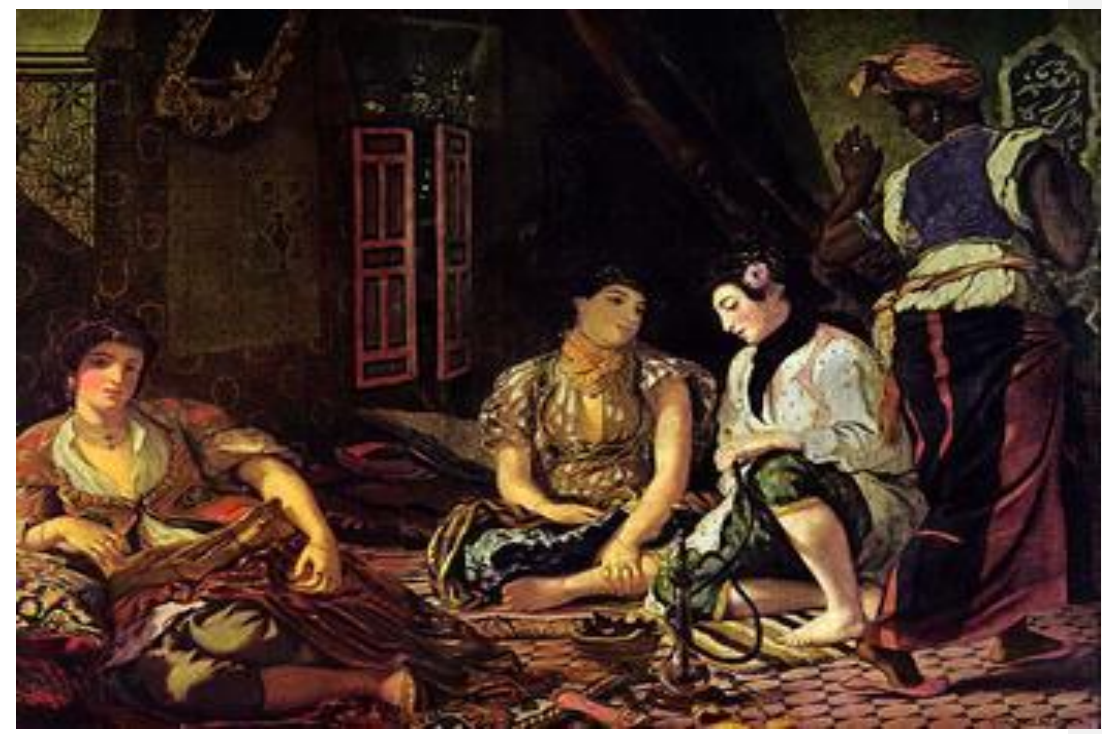

Figure 25. Eugène Delacroix, Women of Algiers in their apartment, 1834,

Musée du Louvre.

When photography was invented in 1839 (Newhall 2009, 18), it added new dimensions to the depiction of the Orient which spanned a wide spectrum of genres, from tourists' photographs of the Pyramids to images of veiled women. The photographs of the Orient woman had its "genealogical beginnings in Orientalist paintings of the Odalisque" (Behdad and Gartlan 2013, 28). At its nascent stage in the nineteenth century, photographs of Oriental women bore striking resemblance to paintings, its progenitor. Both genres had by and large, exoticised and eroticised the Oriental woman as the forbidden fantasies of the Western male. Impressions from travellers' tales, literary works and paintings were woven together and manifested themselves in the forms of the harem and the odalisque. 
The Western male subjugation of the Oriental female is based, as Abdul JanMohammed argues, on seeing the world as divided into "mutually excluding opposites: if the West is ordered, rational, masculine, good, then the Orient is chaotic, irrational, feminine, evil" (quoted in Ziauddin 1985, 62). It provided Europeans with a justification for colonisation, as other cultures were viewed as lesser, backwards and in need of "white salvation".

"Photography was key to the evolution and maintenance of Europe's distinctively Orientalist vision of the Middle East" (Behdad and Gartlan 2013, 1). Nissan N. Perez $(1988,50)$ lends strength to this argument when he said that photography as a medium allowed the Occident to perpetuate its distorted concepts of the Orient and that "these attitudes are mirrored in many of the photographs taken during this time (19 ${ }^{\text {th }}$ century)." According to Michelle L. Woodward (2017, par. 8) who wrote online in Photorientalist, the Orient was the first destination outside of Europe to be subjected to photographic visual records of its people, architecture and landscape. Hence, from the time when photography was invented in the early $19^{\text {th }}$ century, the residual effects and influences of Orientalism from paintings had found a new and convenient platform with which to disseminate skewed and distorted images of the Orient in what appears to be a more lifelike form.

\subsection{Postcards from the Orient}

For many Europeans who did not have the chance to visit the Orient, one of the ways in which they could get acquainted with the region was through postcards. Malek Alloula described the early twentieth century French postcards of the Maghreb as the "fertiliser of the colonial vision" (quoted in Behdad and Gartlan 2013, 3). As literary works and paintings might not be easily accessible to the public, postcards were more 
affordable. Here are some examples of the portrayal of the Oriental woman, redolent of Ingres' Grande Odalisque.

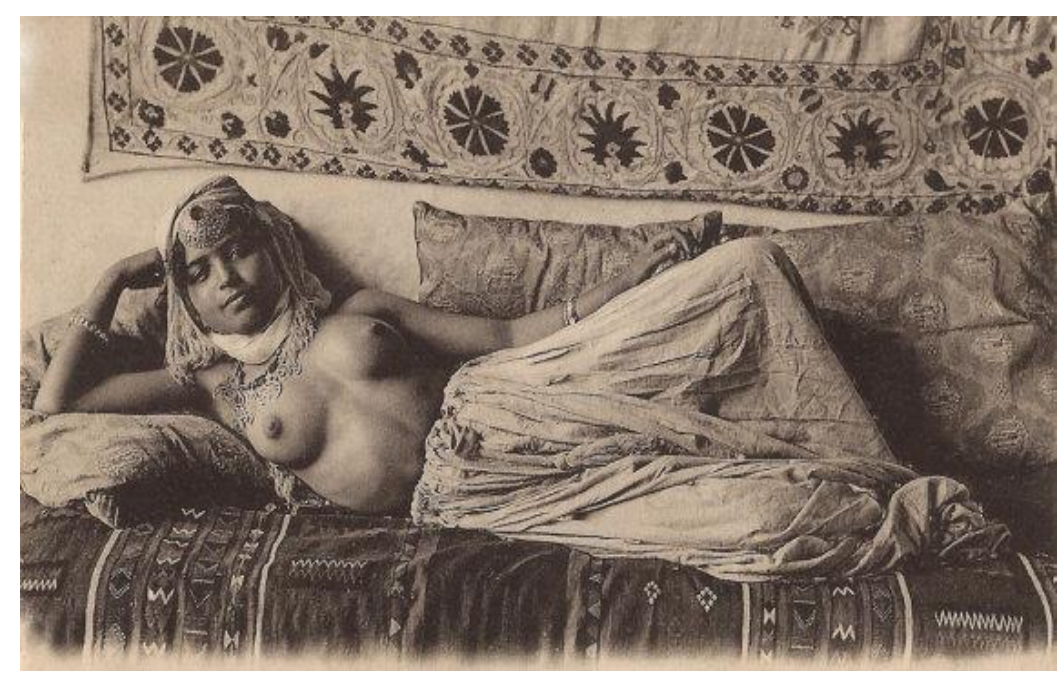

Figure 26. Arabian Nights Harem Nude Courtesan Waiting in Bed, 1910s, French Collectors Photo Postcard.

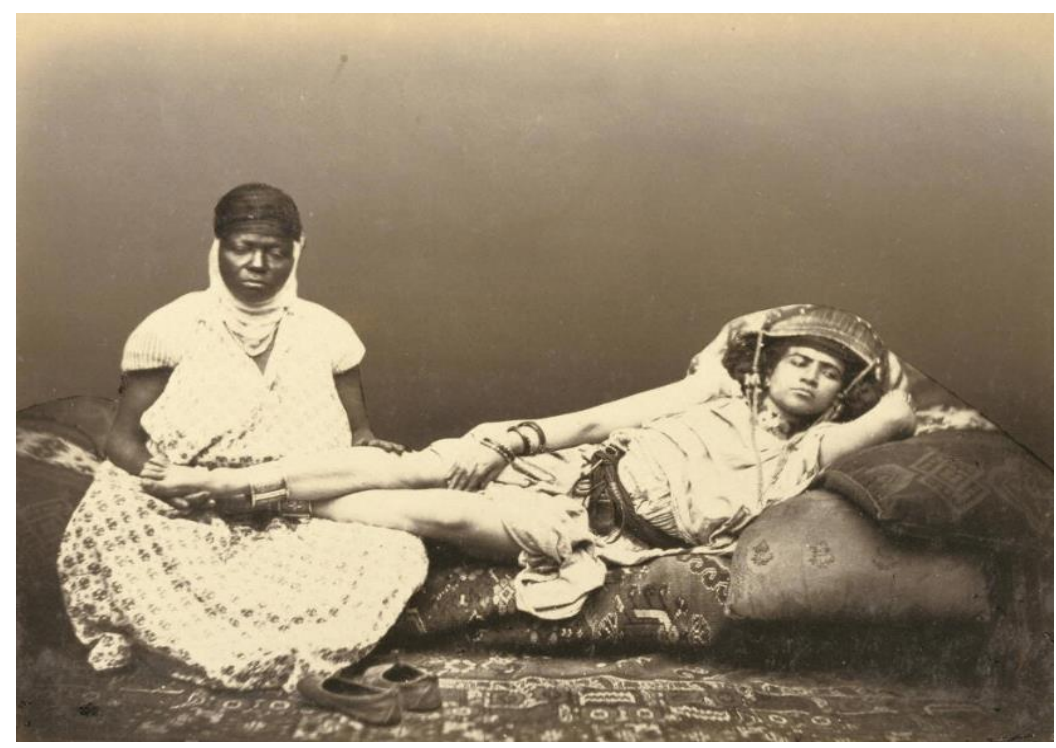

Figure 27. Félix Jacques Moulin, A Moorish woman with her maid, 1856 
With the proliferation of photo studios (Woodward 2003, 363), female models were actually hired for staged photographs with sets and props specially constructed to resemble that of an Orient harem. At times, thinly veiled as staged 'ethnographic' documentation, accessories and headgears were used to accentuate the idea of an exotic otherness. In order to fulfil the erotic whims and desires of the Western male's fantasies, models assumed poses that were sexually provocative and assumed alluring facial expressions. This was partly a curious reaction to the fact that the harem was forbidden to the eyes of male foreigners and partly an act of sexual and cultural domination. These images can be regarded as both voyeuristic and exploitative as it signifies the unequal power dynamics between the Orient and the Occident.

Almost one and a half centuries later, after the British and French empires collapsed in the wake of decolonisation, the legacy of Orientalism still resonates today. Hannah Feldman, Rob Linrothe and John Tagg $(2013,7)$ maintained that the "discourses of Orientalism are not restricted to a temporal period or geographic location but remain pertinent to subsequent practices of visual representation after the era of so-called decolonisation."

It is important to point out that not all photographic works of the Orient from the early nineteenth century onwards reflect an Orientalist's views. As Behdad and Gartlan $(2013,4)$ put it, "photographic representations of the Middle East do not entail a binary visual structure between the Europeans as active agents and Orientals as passive objects of representation. And just as Western photographic representations of the Middle East are not all expressions of colonial power, indigenous practices of photography do not necessarily constitute a locus of resistance to Orientalism." 
3.3 The portrayal of female refugees from the Orient

As an extension to the analysis of how Oriental women have been portrayed through paintings and photography, this section seeks to focus on how female refugees from the Orient have been visually depicted via photography only. This will be further narrowed down to a discussion on how female refugees in the Shatila Refugee Camp have been portrayed. The intention is to lay the groundwork in which to examine Rania Matar's work on teenage refugee girls living in the camp as well as my own photodocumentation of Zeinab who has lived in Shatila Camp for more than fifty years.

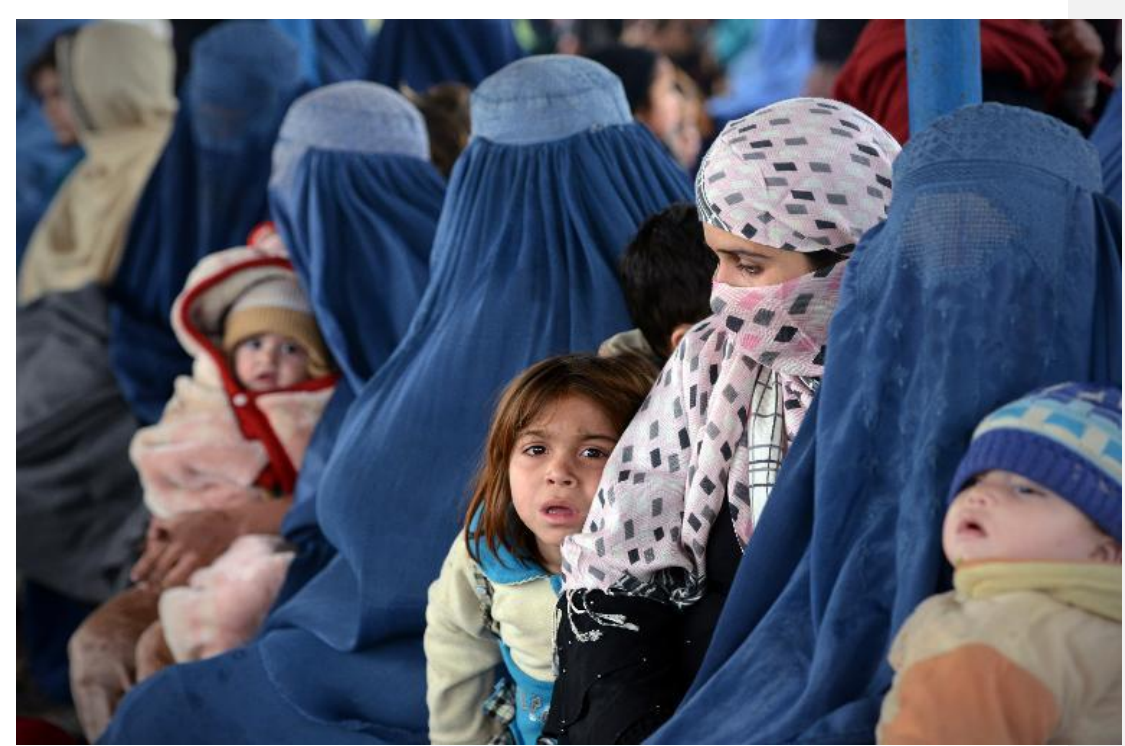

Figure 28. A. Majeed, Untitled, 2015

Female refugees of Oriental origins have often been portrayed as the helpless other who passively await the help of the developed nations to intervene and rescue them. Malkki says that they have been "construed as a universal category with privileged claims as victim subjects" (quoted in Langlois 1996, 390). They have been victimised in three ways: firstly, Oriental women have often been portrayed as powerless beings, subjected to a "manipulative cultural system in which the Arab female has been, perhaps more 
systematically than the Arab male, dehumanized and disincarnated" (Mehdid 1993, 19). Secondly, as a result of the circumstances (be it wars or disasters) which have rendered them as victims of displacement and thirdly through the act of regarding their corporeal bodies as vessels symbolising their suffering. This transformation of "bodies into facts can also be perceived as a patronising enterprise that infantilises refugees" (Langlois 2015 , 6) which could potentially silence them even more. These three points fit into Agamben's idea of the homo sacer.

To add to the existing (visual) literature on the representation of women of the Orient, some contemporary photographic images will be examined in terms of whether they distort, inform or demean the image of the female subaltern. This silencing of the female subaltern (homo sacer) has its ethical implications (figures 29 and 30). In the famous photograph of the Afghan girl taken by Steve McCurry in 1984, the years of suffering as a war refugee, as well as the fear and apprehension of the future brought upon the young child are vividly portrayed through her eyes. The photograph became the emblem of a female subaltern suffering in distant lands, meant to elicit compassion from Western eyes. She is a classic example of how nameless refugees are reduced to symbols. Her identity and whereabouts came to light only after almost two decades when in Jan 2001, Steve McCurry and a National Geographic team travelled to the Nasir Bagh refugee camp in Pakistan which was about to be demolished and located her (Washington Post 2001, par. 1). It was only then that she was identified with a name, Sharbat Gula, along with a revelation of her personal story.

Besides running the risk of reducing refugees to symbols, the aestheticisation of the suffering of refugees entails ethical implications as well. This situation is exemplified by the stunning black and white portrait of a female refugee from Gondan, Mali by Sebastião Salgado (figure 31). At first glance, one is struck by the transcendental beauty 
of the image as the subject's face is illuminated. It is only upon reading the caption "with dead eyes worn out by sand storms and chronic infections, this woman from the region of Gondan has arrived at the end of her voyage" (Quach 2010, 77) that one realises the severity of her plight. Even though her facial expression encapsulated pain and misery, Tiffany Quach $(2010,77)$ mentioned that Salgado's works have been criticised for his "penchant for imbuing the tragic with beauty that transcends the reality of the situation... at the expense of the viewer's immediate concern." Indeed, as any artist who is always striving to produce good work, one is faced with a moral dilemma when photographing tragedies or suffering. The act of aestheticising misery is on one hand, morally questionable while on the other hand, there is a potential to relegate the gravity of the situation into the backseat. These two portraits discussed, though very powerful, have the tendency to reduce the subjects to signifiers as the identities of the woman and the Afghan girl were unknown at the time when they were photographed and published. They also serve as reminders of the power that the photographer holds over them, the subjects as refugees. Hence, Lévinas' philosophical tenets of the responsibility for the other, as well as the face apply here.

The portrait of another veiled Oriental female in figure 30 which won the World Press Photo in 2010, serves as a contrast. Taken by Jodi Bieber, the identity and background of the subject is revealed. Instead of portraying the subject as a victim, Jodi Bieber captured the strength and defiance of Bibi Aisha which showed her as a survivor. In an interview with Sarah Phillips (2010) in the Guardian, Jodi Bieber mentioned that she, "thought that TIME was going to be disappointed because I didn't show Aisha as a victim." This statement provides an insight into the politics of the reportage industry which plays a vital role in how images of victims should be portrayed. Photographers had to contend with what the editors and the industry want and expect of them and this 
in turn influences their work and vision. By contrast, in my case, I can shoot freely without any constraints as I am not bound by any assignments or editorial control.

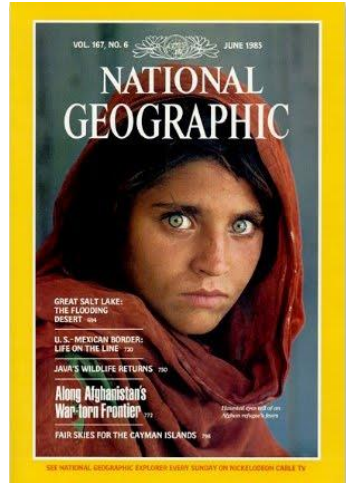

Figure 29

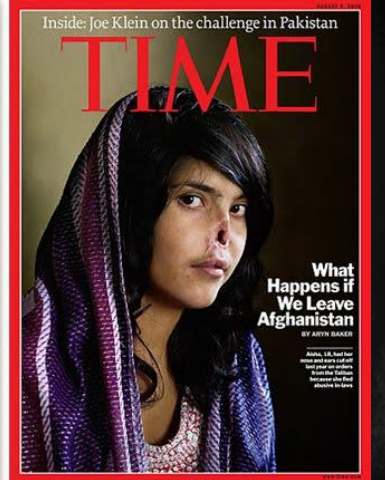

Figure 30

Jodi Bieber, "Bibi Aisha", 2010

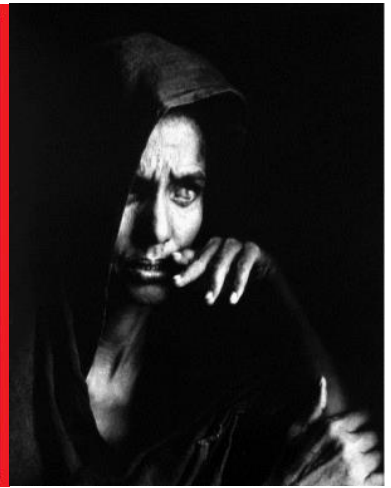

Figure 31

Sebastião Salgado, "Refugee from Gondan Mali”, 1985

Another conventional portrayal of refugees (not only confined to female refugees from the Orient but to refugees across the board) with universal appeal is that of a mother and child image. This particular form of iconography where mothers are juxtaposed with "starving, emaciated babies and children creates a tension within Western ideology" (Ali, James, and Vultee 2013, 13). The 'Madonna and child' image which is intrinsic to Christian iconography represents a "sentimentalised, composite figure - at once feminine and maternal, childlike and innocent... is an image that we use to cut across cultural and political difference, when our intent is to address the very heart of our humanity" (Malkki 1996, 388). One of the most common aims of using such photos is to garner humanitarian support and to raise funds by alluding to the idea of maternal love and the innocence of childhood. Such images are meant to tug at the heartstrings of viewers and to justify international aid and intervention. This could become a double-edged sword for it can 
further reinforce the powerlessness of women, by fitting them into a narrative of victimhood, constructed by the various aid agencies (Langlois 2015, 6). Just as photographers feel the pressure to conform to news industry standards regarding how a victim should be portrayed, the same issue is faced when images are produced for humanitarian organisations. The image of victimhood is reinforced by Liisa H. Malkki $(1996,388)$ who says that "this vision of helplessness is vitally linked to the constitution of speechlessness among refugees: helpless victims need protection, need someone to speak for them. In a sense, the imagined sea of humanity assumes a similar helplessness and speechlessness." Female refugees are thereby further silenced due to their circumstances, culture and gender.

In the portrayal of refugees as victims, the inclusion of women and children normally evokes pity and empathy as they are deemed as more vulnerable when compared to able-bodied young male migrants. Drawing inspiration from biblical references, the pieta-like iconography of a mother holding her child is an oft-repeated image on advocacy posters for NGOs appealing for donations. 


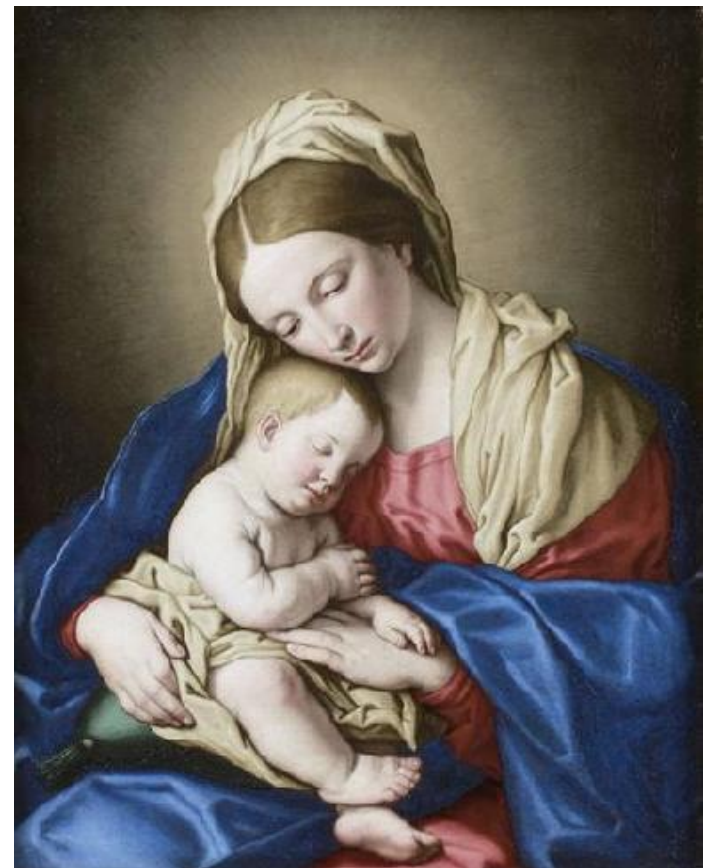

Figure 32. Giovanni Battista Salvi II Sassoferrato, Madonna and Child, 1609-1685

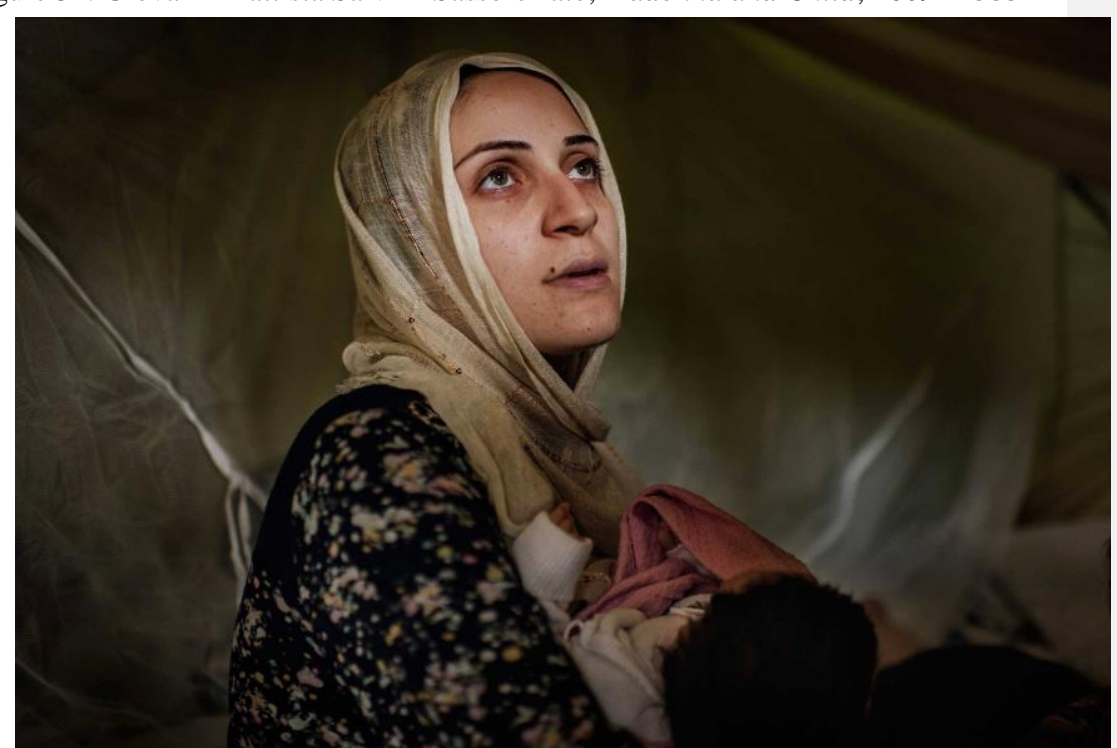

Figure 33. Lyndsey Addario, Taimaa Abazli, 24, holds her new baby Heln in their tent at the Karamalis camp in Thessaloniki, Greece. 2016 
3.4 The portrayal of female refugees in Shatila Camp

Having established the background of how female refugees from the Orient have often been portrayed in general, this section will focus specifically on the depiction of female refugees from Shatila Camp. A search was conducted in the archives of various photo agencies such as Magnum Photos, AP Images, Reuters Pictures and the European Pressphoto Agency (EPA) using the following keywords - Shatila and woman. The recurring representation of the female refugees living in Shatila Camp are as follows: 1) the veiled woman wailing over dead bodies after the 1982 Sabra-Shatila massacre, 2) the mothers of martyrs of the Lebanese Civil War (1975-1990), 3) women and key Palestinian political figures e.g. Yasser Arafat and 4) mothers with their children (without the presence of their men in the frame). Such images fit well into the Orientalist's representation of women as victims of the chaos that characterises the region.

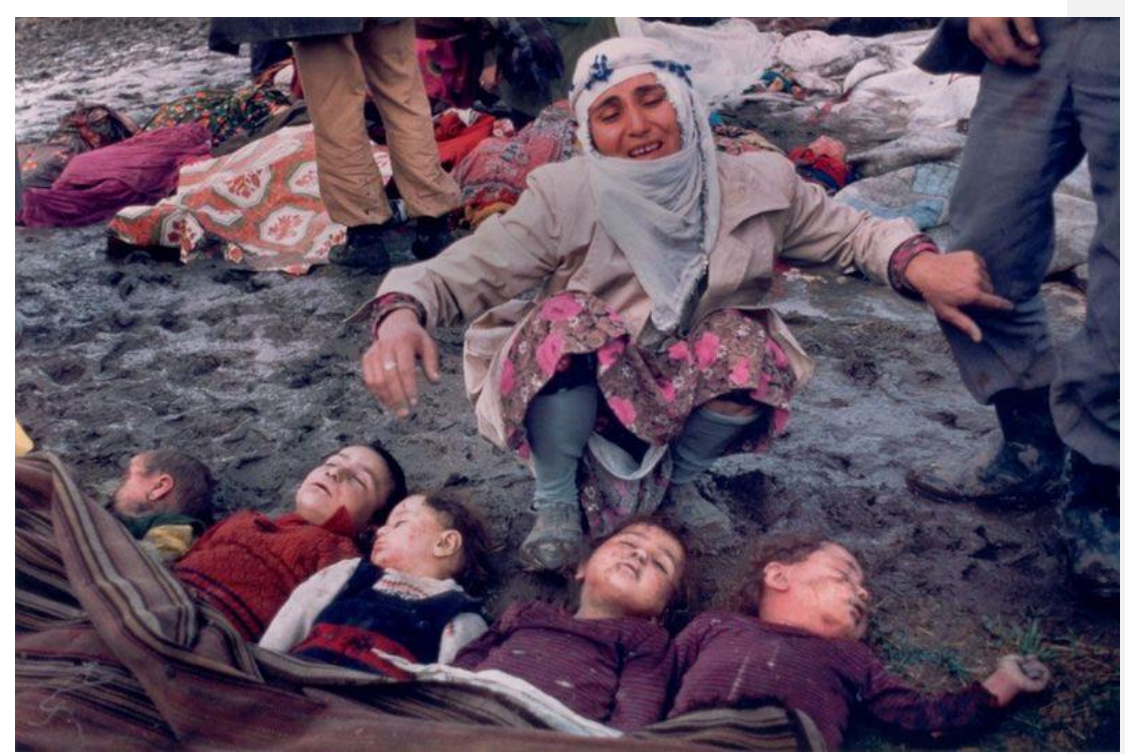

Figure 34. Palestine Chronicle. The Sabra-Shatila massacre was just one of Sharon's terrorist achievements on behalf of the state of Israel, 1982. 


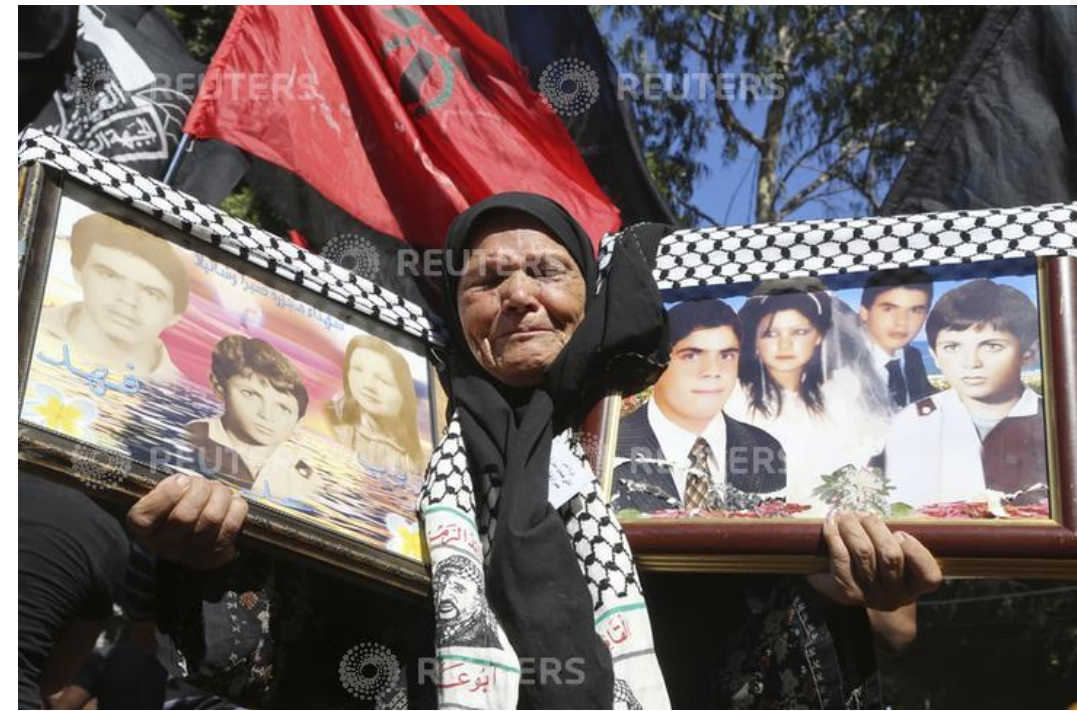

Figure 35. Sharif Karim. A Palestinian woman reacts as she carries portraits of her relatives who were killed during the Sabra-Shatila massacre in a march to mark the 32nd anniversary of the massacre in Beirut September 19, 2014.

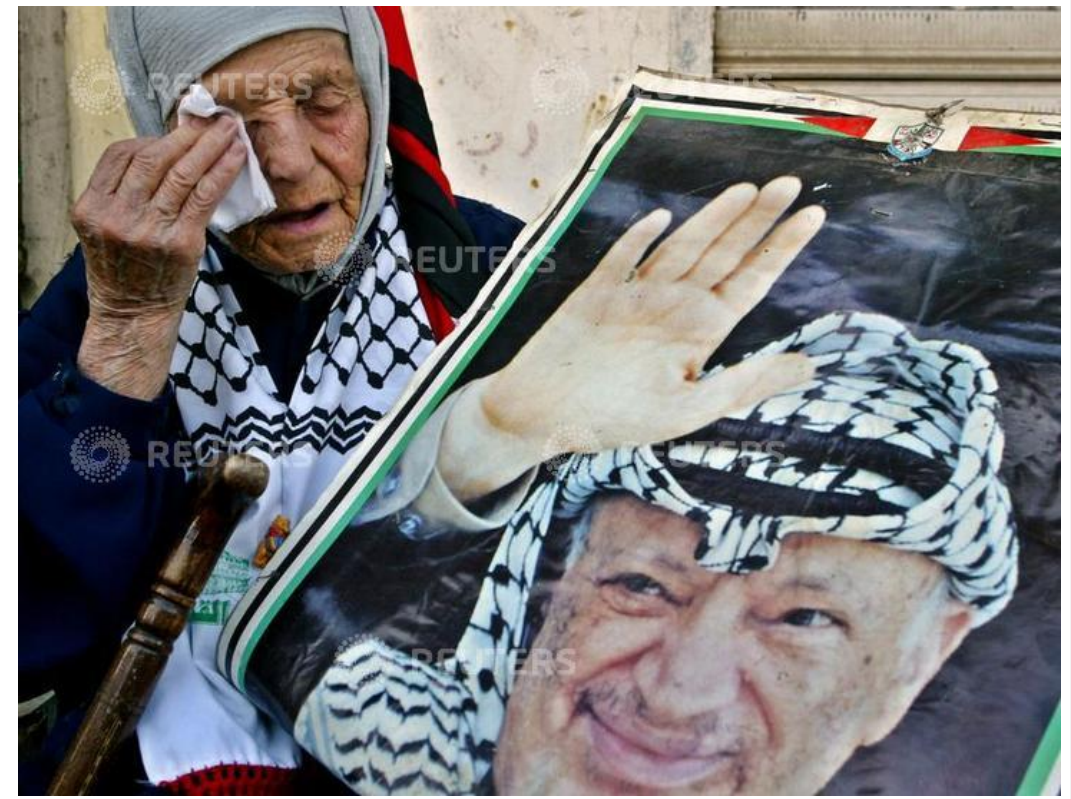

Figure 36. Mohamed Azakir. A Palestinian woman mourns the death of Palestinian President Yasser Arafat in Shatila refugee camp in Beirut November 11, 2004. 
On the other hand, Laif Photo Agency took an alternative approach in portraying the women of Shatila Camp. They depict women carrying out affirmative roles such as working and being independent in the camp. This photo series is a rare exception which broke the convention of how women have often been depicted in the refugee camp and by extension, how women had been constantly portrayed as in the Middle East at large as veiled, helpless women without any agency of their own (figures 34-36) or crying over tragedies.

\subsection{Rania Matar - A Girl and Her Room}

In the quest to discover how Shatila Camp had been portrayed by other photographers, a search was conducted on both Google and Yahoo using the following keywords: Shatila Camp. Upon close examination of the first 2 pages, both search engines yielded similar images that generally depict:

1. The harsh living conditions of Shatila Camp with wires and water hoses crisscrossing from one dilapidated building to another.

2. Children running around the chaotic, narrow lanes of Shatila, often filled with rubbish.

3. Special events such as Land Day and Al Nakba Day commemorations.

4. Images of the aftermath of the 1982 Sabra-Shatila massacre.

5. Sporadic images of events taking place indoors e.g. Western volunteers conducting some activities with children in Shatila Camp.

6. A few images of subjects photographed indoors.

While the documentation of the living conditions is an important and an integral part of my long-term project, it is the interaction and long-term engagement with my subjects that differentiate my work from many of the photographs displayed in the search engines. It is assumed that many of the images shown (especially those which fit into the 
categories numbered from 1-5 above) could be works of photojournalists on day assignments. As there are often deadlines to meet, assignments are more often than not, accomplished in a hurry and reportage appears to be cursory. Such an approach, also known as 'parachute journalism' stands in sharp contrast to mine which is characterised by long term, in-depth coverage in which rapport with my subjects has to be established. Moreover, many of the images found appears to be single images which is possibly not part of a larger series.

Out of a few hundred images of Shatila which appeared on both search engines, it was the very few images in category 6 which struck me. These images bore a distinctive motif - environmental portraits of a teenage girl in a bedroom, with almost all of them looking into the camera. A further search led me to Rania Matar's website on her work 'A Girl and Her Room' which revealed a photo series of teenage girls, predominantly from the USA and Lebanon. Her works served as vital points of comparison for my own, as we both share some similar approaches and our works are personal. We both dealt with elements of Shatila Camp on a much deeper level than most photographers on short assignments do. Moreover, Matar had gained access into private domains like I had done, illuminating another facet of life in Shatila which is often overshadowed by the focus on its chaotic camp-scape.

Why is Rania Matar's work relevant in this paper? The first impression one gets (prior to reading her artist statement) is that the photo series is a privileged peek into the privacy of teenage girls in their bedrooms and how they interact and behave in this intimate space which is like "a womb within the outside world" (Matar 2009, 1). My aim was to first let myself form my own interpretation and not be influenced by Matar's statement. Of particular interest to this paper is how much semblance her teenage female subjects bear to the Odalisque in the way they posed themselves, channeling strong hints of the aesthetic of Orientalism. In fact, in some of the images, the poses and glances of 
the girls evinced uncanny resemblances to the postcards and paintings discussed in the preceding chapters.

Even though Matar has not consciously embraced or adopted elements of Orientalism in her works, as she has not mentioned this point at all in her artist statement, it is evident that some of the images in her photo series A Girl and Her Room exude traits of the Odalisques. While she has not explicitly mentioned if the mise-en-scène in her photographs were staged or not, the 'theatrical' arrangement of the objects in the bedrooms of the girls did seem contrived. The various 'props' or belongings of the girls are harnessed and included (possibly arranged by the girls themselves) in the frame to bring out the fragility of the formative stage of a teenager's life. This is reflected in her artist statement, "The room was a metaphor, an extension of the girl, but also the girl seemed to be part of the room, to fit in, just like everything else in the material and emotional space" (Matar 2009, 1).

To further illustrate the point, one can sense this emerging sexuality as exemplified in figure 40, in which the props included in the frame such as the pink bra on the wall, the poster of Marilyn Monroe striking a suggestive pose in bed as well as the evocative look on the subject, Christilla's face, all add up to the idea of a teen metamorphosing into womanhood. Moreover, it is apt that the subject is positioned below the poster of Marilyn Monroe, that both of them are blond and fair-skinned, wearing suggestive facial expressions. Even though it is not an intended consequence on Matar's part, Christilla's posture is reminiscent of Ingres' iconic painting of the Grande Odalisque (figures 24 and 40).

While Christilla from Lebanon, as her name suggests, is definitely not a Muslim, she serves as a sharp contrast to a few other girls in the series who reside in Shatila Refugee Camp. In an interview with Elizabeth Avedon, Matar reviewed how she became 
interested in learning about her Palestinian identity and how this desire was "buried in there somewhere" (Matar 2014) which led her to include girls in the Palestinian refugee camps in her work such as Shatila.

The concept of the Palestinian refugees living as homo sacers in the camp is evident here as seen in the setting of the photographs (figures 37-39). It clearly reflects the 'bare life' which Giorgio Agamben $(1998,4)$ mentioned in his seminal book Homo Sacer. In contrast to Christilla who lives in the upscale neighbourhood of Rabieh in Greater Beirut, the Shatila Refugee Camp lies in the 'misery belt' of Southern Beirut where many Palestinian refugees live. The furnishings in Christilla's room as compared to those found in the bedrooms of Elham (figure 37), Hiba (figure 38) and Amal (figure 39) speak volumes about the class differences in Lebanon as well as the social exclusion of the Palestinian refugees living in Shatila Camp from the rest of Lebanese society.

Yet, it is interesting how Matar has blurred the distinction between geographical and cultural boundaries to create an inclusive series of images of teenage girls of vastly different backgrounds, on the cusp of reaching adolescence. It does not matter whether one is born a refugee in Lebanon or in a privileged home in the United States, Matar wants to drive home the message that teenage girls face mostly the same issues regardless of their background.

As for our modus operandi, we both spent time to get to know our subjects and to gain their trust. This is reiterated by Matar $(2009,1)$ as follows, "I always spent time with each girl, so she was comfortable with me and eventually the photography session became a beautiful and intimate collaboration."

By contemplating the girls as aesthetic objects, Matar's images seemed contrived and staged in a very particular way and collaboration is apparent between the photographer and her subjects. It appears that Matar is consciously trying to create 
images of the teenage girls who are confrontational to the camera. The subjects are clearly aware of and reacting to her as a photographer as some of their faces look straight into her camera while some wore a haughty, defiant look (figures 38 and 39).

It is imperative to distinguish the genre in which Matar is working in. Unlike James Nachtwey, Susan Meiseslas and I who use photojournalism as a medium to tell stories. Matar is photographing in the tradition of fine art photography. She is a visual artist working on her personal art project, more in the footsteps of Richard Avedon who used portraiture to convey his vision of what America is (Avedon and Wilson 2003).

Of particular relevance to my-long term documentation of Shatila Refugee Camp are the environmental portraits of teenagers shown in figures 37-39. All of these photographs were taken in Shatila refugee camp in 2009 and 2010, rather close to the timing of my own venture into the camp starting from 2010. In all three images, the conditions of the girls' bedrooms seemed run-down and the furnishings are spartan and modest. This reflects the same conditions of some of the families I had visited in Shatila Camp. Moreover, in the bedroom of Elham (figure 37), a poster of Sheikh Ahmed Ismail Hassan Yassin, the founder and spiritual leader of Hamas, an Islamist Palestinian paramilitary and political party, can be found on the far-right corner of the frame. This political-religious insignia is found only in this image out of the entire series of A Girl and Her Room which highlights the politicised landscape of Shatila Camp. It is a reality which the camp residents have to face and live with unlike girls who grew up in vastly different societies in the USA. In figure 38, the portrait of Hiba, sans hijab as she donned a dress with a print of a western lady suggests a teenage girl trying to break the constraints of how Muslim girls should dress. Finally, in figure 39, Amal's pose is a striking resemblance to that of a sticker of Miley Cyrus on her wardrobe. The look of defiance on her face is unmistakable and her T-shirt depicts a rock star even though she is wearing 
a hijab. It hints at the tension of what she is expected to be and what she actually desired to be, as expressed through the décor in her room and her decorum.

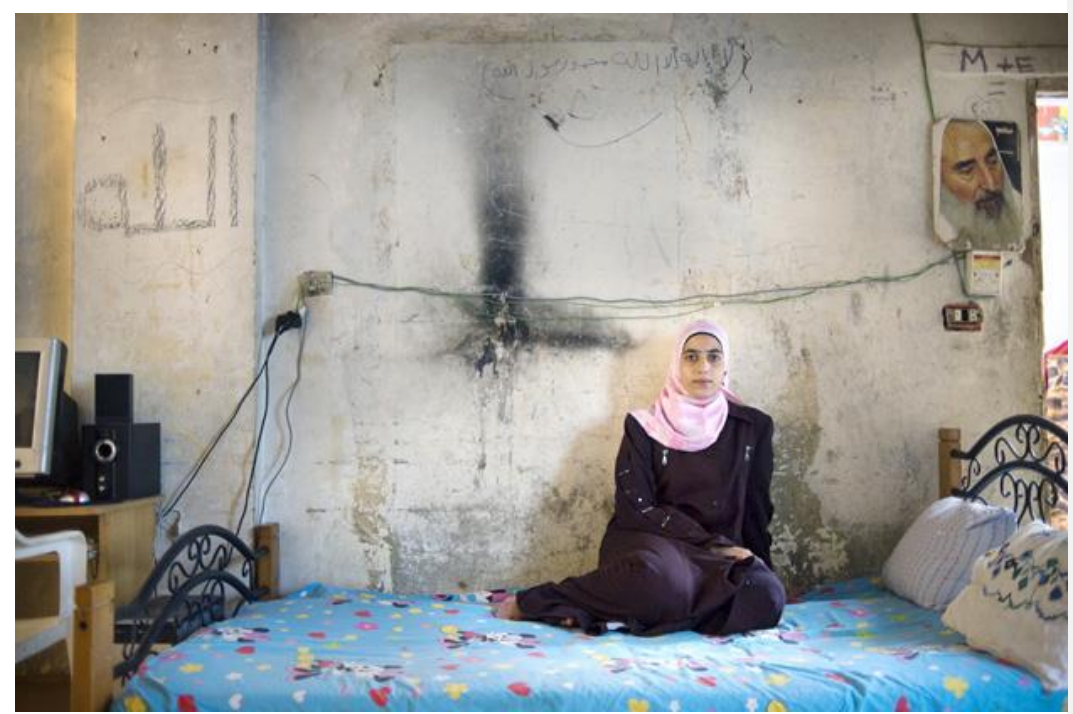

Figure 37. Rania Matar, Elham, Shatila Palestinian Refugee Camp, Beirut, Lebanon, 2009

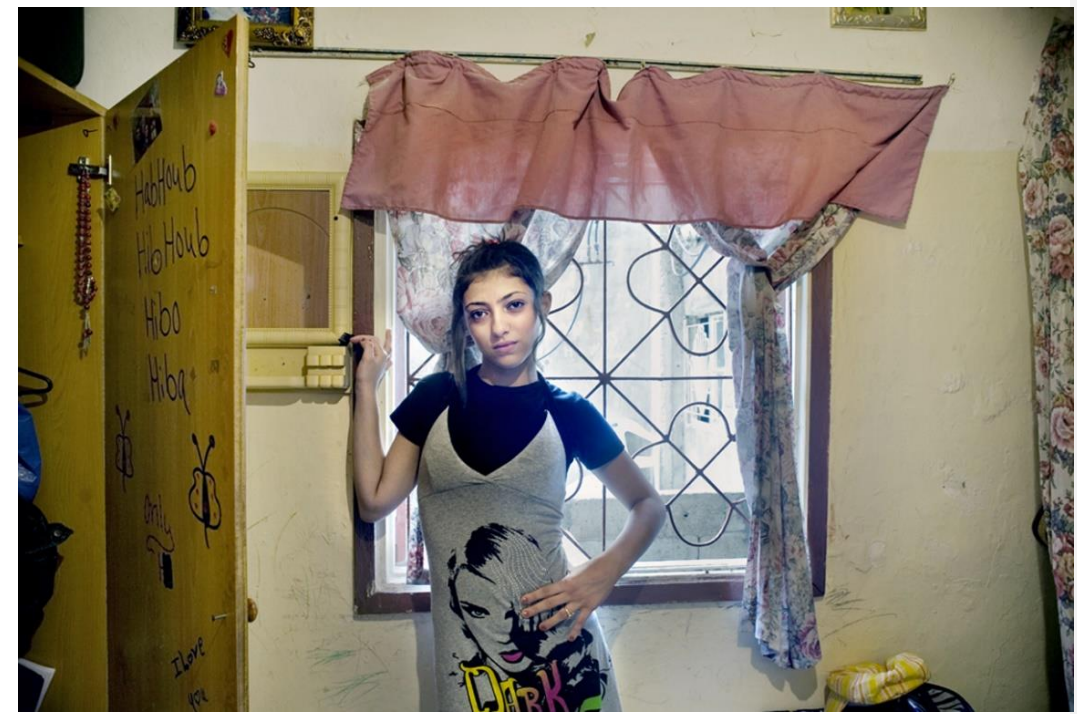

Figure 38. Rania Matar, Hiba, Shatila Palestinian Refugee Camp, Beirut, Lebanon, 2010 


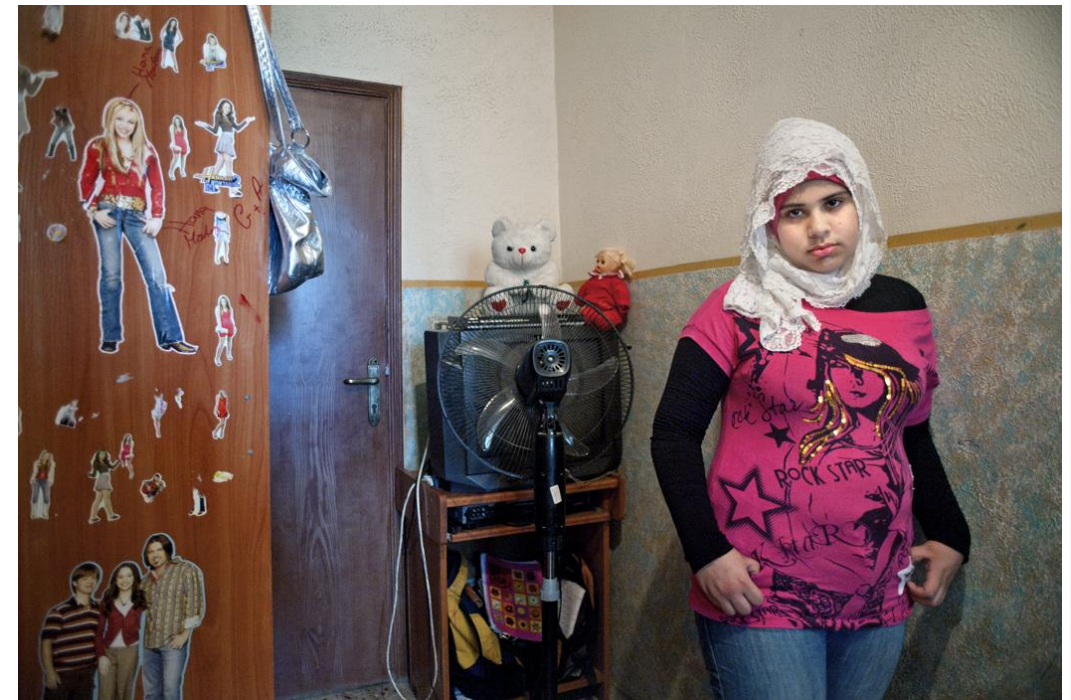

Figure 39. Rania Matar, Amal, Shatila Palestinian Refugee Camp, Beirut, Lebanon, 2010

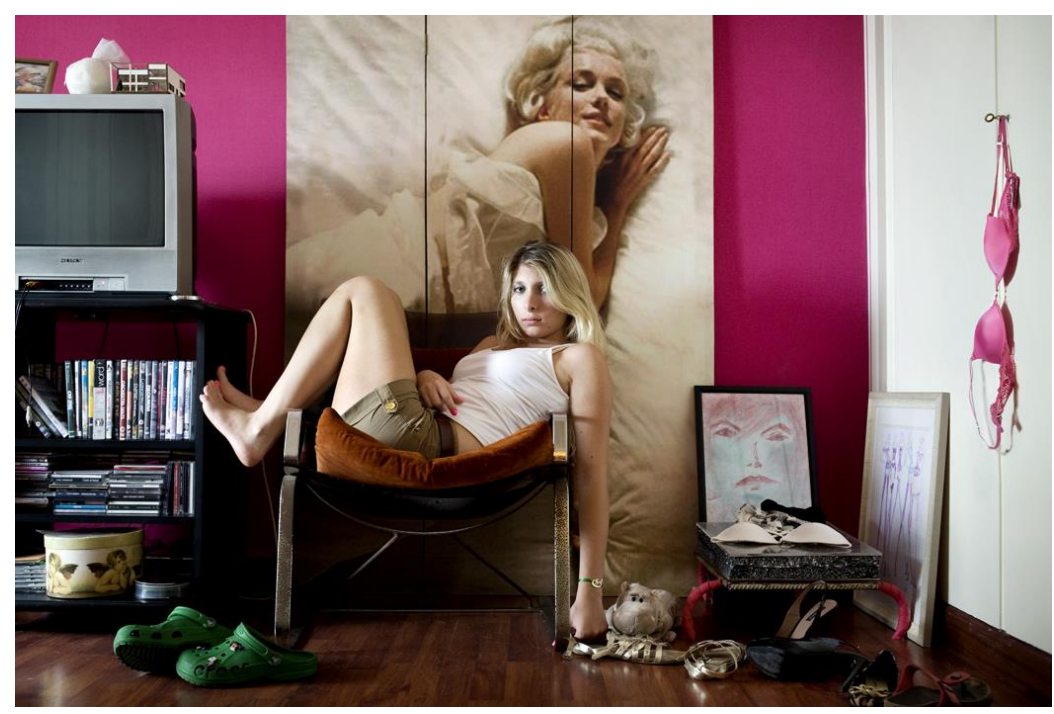

Figure 40. Rania Matar, Christilla, Rabieh District, Greater Beirut, Lebanon, 2010

The analysis of these images functions as a point of focus in which I can draw a parallel to in my work on Shatila Camp later in this paper. It is imperative to point out that all these subjects are given a face and name, in order to humanise the subjects and 
issues in which they represent. This series of photos defy the convention of how female refugees are often portrayed as 'victims' which will be further explored.

3.6 Zeinab's story: Giving a face to Shatila's residents

To take a photograph is to participate in another person's mortality, vulnerability, mutability.

Susan Sontag

Instead of just narrowing the photo-documentation of Shatila into a compilation of single images depicting misery, the scope of my documentation was widened to encompass as many aspects of camp life as possible. I have chosen to include and photograph in detail the private domain of a selected subject, Zeinab and her extended family in the form of a photo essay. Following the tenets of long-term documentary photography, I embedded myself within the community of Shatila and followed the life of Zeinab closely over the past four years (2012-2016). The rapport nurtured with Zeinab since 2012 has allowed me to gain trust and facilitated the continual access into her home. This long-term immersion enabled me to photograph her living conditions, daily activities, social and cultural habits and delve deeper into her psyche. The choice of Zeinab and the focus on her and her family not only puts a human face to the thousands of refugees in the camp but also aids in bridging the emotional distance between the viewers and the camp residents.

The reasons for choosing her are manifold. One of the most important factor is that Zeinab occupies an interesting position within the camp; her sewing machine is situated outside her home which acts like an extension to her place of residence. This feature is something unique in the context of Shatila where not many residents set up businesses and earn their livelihood outside their homes. It is an ideal location not just to document her life but also to watch people walking by as her sewing machine is located at a prime spot where human traffic is heavy. Zeinab's relatives, friends and neighbours found the 
space around the sewing machine an ideal area for socialising. Thus, it became a hotbed and repository for gossip about the latest happenings in the camp. By photographing her where she works, a place where her home and work life intersects, it makes the still photographs visually and narratively rich in content. Not only am I able to take photos of her as she interacts with her friends and family, I am also able to include snippets of life in Shatila along the lane where she works. Typically, people do not venture far and kids play along the lanes as motorbikes try to negotiate their way through the congested alleys. It is routine to see the same people doing the same things day after day, the same people smoking water pipes and the same kids playing for example.

Besides being a conduit in which one can gain deeper insights into life in Shatila Camp through the visual narrative of Zeinab, I also sought to defy the convention of how Arab women have often been portrayed by the media. Other than the recurrent images of the Oriental female refugees waiting passively for aid or women in Shatila Camp wailing over bodies after the massacre in 1982, Oriental women have often been typecast as "idle females imprisoned within a harem, reduced to drinking coffee, smoking the hookah, dancing, reclining and conversing; above all, stagnating in immobility, inertia and insensitivity" (Mehdid 1993, 25).

The perpetuation of this distorted image of a submissive and passive woman of the Orient is challenged by the depiction of Zeinab as a non-veiled woman who is a symbol of independence and strength.1 Zeinab is a divorced mother of five, who raised her children single-handedly as a seamstress. Her resilience in the face of hardship and suffering speaks for many residents in Shatila Camp.

1 It is important to clarify that just because a woman is not veiled, this does not necessarily imply that she must be strong and a veiled woman must naturally be perceived as weak. 


\subsubsection{Seeing Zeinab's life through Portraiture}

A photographic portrait is a replica or mirror image of a person's facial features and physique. Yet, a portrait serves more than just mimetic functions. It is a powerful form of visual representation that can reveal a person's social status, economic conditions and even their psychological states. As Susie Linfield (2010, 40) says, "the best photographic portraits, like the best-painted portraits, present us not with biographical information but with a soul." For my modus operandi, I tried spending time with my subjects and we conversed about life in the camp. It was when they became engrossed in airing their grievances that I became 'invisible'. The moment their sentiments were at the most intense, I pressed the shutter and captured their raw emotions (figure 41). This added veracity to the portrayal of the residents as I do not stage photographs.

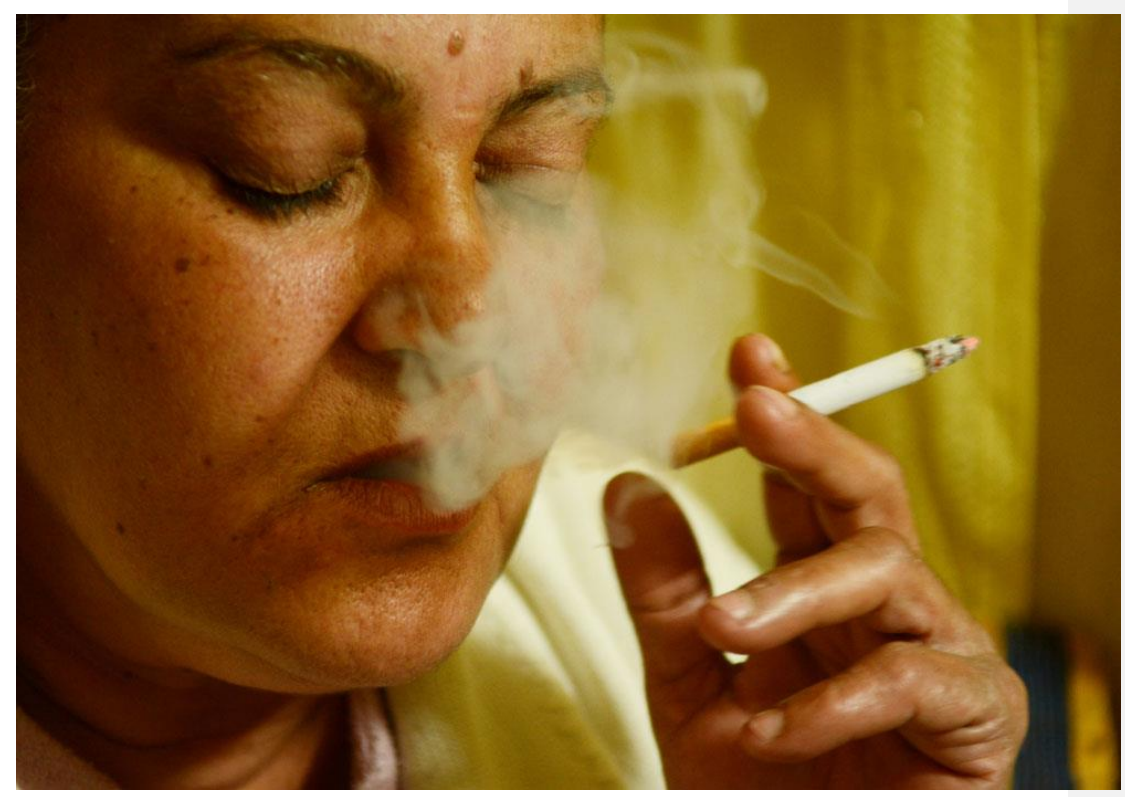

Figure 41. Zann Huizhen Huang, Portrait of Zeinab, 2012 
However, there are limitations to the photographic portrait, Lévinas $(1978,55)$ points to photography and film and in particular to close-ups, "as potential sources of alienation from the enworlded and pre-digested thing." This refers to how a photographer who was present at the location in which the images were taken had knowledge of what the surroundings and situations were like. It also means that the image of the face enables one to interact with the subject which can actually strip away the "message" of the photographer. Conversely, the message could turn the face into a theme of the photographer's which could result in denying the reality of the face seen.

In the process of image making, the photographer is not only an eyewitness but also acts as the mediator to bridge the gap between the viewers and the subjects' world as the photographer selectively determines the subject-matter which s/he wants to convey. The close-up shot taken thereafter would be a product of what the photographer sees and filters through her/his consciousness.

Using Zeinab as an example, we will look at the power dynamics and the ethical ramifications of photographic techniques such as framing. Framing is the deliberate process of 'selecting' information that is salient while precluding the rest. This shapes how the audience views and responds to certain issues. This process is closely intertwined with both aesthetics and ethics. As such framing is a powerful device, it is one of the main techniques to communicate the auteur's intention. It can be highly persuasive, influential and manipulative on what the audience will see which will in turn shape their perception of the issues at stake. Institutional influences such as market demands and editorial control play their roles in shaping the images and thus the viewers' opinions. By contrast, as an independent photojournalist, I am not bound by such editorial expectations and have more freedom in how I create my images. 
It is also essential to acknowledge that the act of photographing can never be an objective process. In this vein, Susan Sontag $(2003,46)$ reiterates that, "to photograph is to frame, and to frame is to exclude." Through the act of photographing, framing is an inevitable part of the process and by extension, the use of cropping as a post-production tool works on similar principles. As for a close up shot, many details would be excluded from the image produced. Hence it is important to include not only close-ups of Zeinab in the pursuit of trying to unlock her psyche, but the attributes of environmental portraits can also be harnessed to reveal more about a subject's life and living conditions.

\subsubsection{Seeing Zeinab's life through Environmental Portraiture}

While a close-up portrait of an individual could reveal her/his emotional and psychological state through the eyes, gestures and facial expressions, environmental portraiture allows the viewer to learn more about the subjects through presenting a larger visual context. The environmental portrait is normally a wider angle shot achieved by using a medium to wide focal length lens. This would broaden the angle of vision to include the surroundings of the subject and how they interact with their immediate environment (figure 42). This is vital in my exploration of how the residents cope with living in an ever-shrinking space as the population of the camp expands exponentially. Some of the ethical issues which could potentially occur include an intrusion of privacy, but in my work the subjects are aware of the presence of I, the photographer and consent has been given to be photographed. 


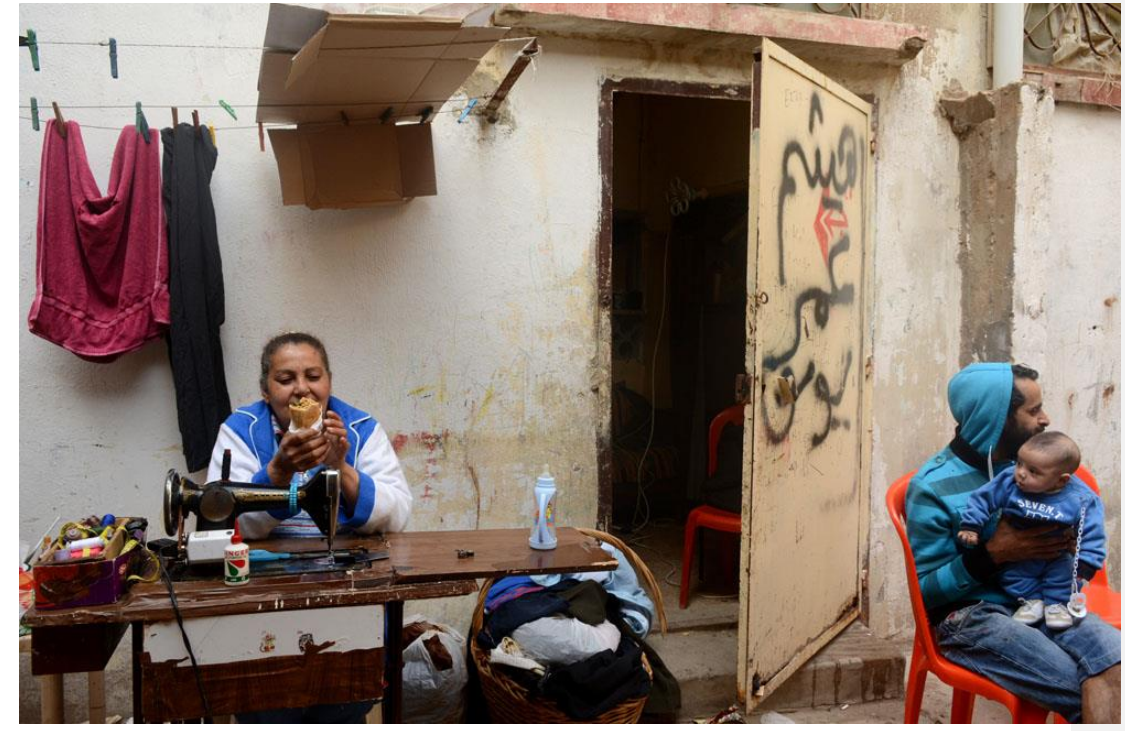

Figure 42. Zann Huizhen Huang, Zeinab and her workspace outside her rented home. Her son is carrying the baby of her daughter, 2012

By zooming in on one subject in order to see Shatila through the perspective of a single individual, there are many ethical considerations to be made. Hinging on Lévinas' ontological reading of the face, it is the unique feature of each individual and is the organ in which our expressions are written and exposed to the world. It is also a medium through which we 'face' and interact with each other and the world. In his Conversations with Phillippe Nemo in Ethics and Infinity, Lévinas explains how the "skin of the face is that which stays most naked, most destitute" (quoted in Nemo 1995, 86). Hence, the exposure of the face, for instance, in cyberspace could magnify the vulnerability of the subject(s) especially if the work ever gets published online. With the advent of the internet, the dissemination of images could potentially amplify the visibility of my subject exponentially. Therefore, the utmost ethical care and responsibility should be exercised in the representation of the subject(s).

Lévinas states that "Face and discourse are tied. The face speaks. It speaks, it is in this that it renders possible and begins all discourse" (quoted in Nemo 1995, 88). The 
importance of the ethical dimension of this quote by Lévinas is tied closely to how much weight is given to the face in a photograph especially when it is a close-up in an intimate environment such as a subject's private domain i.e. a home. The burden, according to Lévinas would be to make the subject a unique being and not to reduce them to a symbol.

Though I have no control over how my image will be received by the viewer, as a documentary photographer, it is imperative to depict Zeinab's life and psyche as accurately as possible. This is why I do not stage my photographs and my modus operandi is to wait until the subject becomes oblivious to my presence and the shutter will be pressed subsequently. In my interaction with my subjects, there are some ethical points to consider: when facing the other, it is paramount to treat the other as 'greater than oneself'. This is even more crucial in the case of my subjects in the refugee camp who are stateless refugees, deprived of most of the sovereign rights which citizens of most nations would be entitled to. I must take a responsibility to understand and not exploit their vulnerability.

Palestinian refugees living in Lebanon are stateless and stripped of most of their rights, therefore the greatest care and consideration ought to be accorded in dealing with these vulnerable subjects in order to avoid causing them further harm or casting them in a negative and demeaning light. It is vital not to frame Zeinab in such a way that would relegate her to the realm of victimhood in order to solicit pity. The portrayal of Zeinab as a victim could potentially isolate her further from the international community which would not necessarily invoke sympathy. Victimhood and its portrayal could accentuate the differences between the victim and the global audience and thereby widen the gulf between 'them and us'.

It would be a better alternative to narrow this gap by depicting Zeinab as part of the human fraternity, as having the same needs and concerns and trying to lead normal 
lives just like us, while not overlooking her struggles. By endowing Zeinab with an identity as someone who is a mother, a daughter, a friend and a neighbour, it humanises her. It is also important to accord her with agency, as a seamstress who is a productive member of the Shatila community who does not just wait for handouts from charity. Such a portrayal imbues Zeinab with dignity but one has to be vigilant of thematising her by reducing her to mere symbols. As a photographer who holds the power over how a subject should be portrayed, I shoulder a heavy responsibility for the other. As Lévinas (1998, 93) says in our "face to face interaction with another person - seeing that person not as a reflection of one's self, nor as a threat, but as different and greater than one's self." Lévinas moves the reader to recognise the implications of this interaction in our abiding responsibility for the other. This idea of the obligation to and our concern with the other's suffering are very important in dealing with the residents of Shatila (Lévinas 1998, 93). 


\section{Chapter 4}

4.1Analysis of the works of Jacob Riis and Sebastiàn Liste

Based on the lack of thorough and long term photo-documentation of Shatila, an examination of how some photographers accomplished intensive visual coverage of life in other urban slums will be conducted. The photographic styles, approaches and works of Jacob Riis and Sebastiàn Liste will be analysed vis-à-vis the documentation of Shatila Refugee Camp.

Despite the temporal and spatial differences, some elements in these two photographers' works are still relevant to my research. Riis' work was set in New York City circa 1890, he published How the Other Half Lives: Studies among the Tenements of New York which is a compilation of photographs, statistics, demographic charts and anecdotes of his observations of life in the slums. Liste's series (2009-2011), Urban Quilombo2 is an unflinching record of the lives of a community of families that occupied an abandoned chocolate factory in Salvador de Bahia, Brazil. Driven there partly by poverty and partly by the violence that plagued the city, they transformed it into a home. The rationale for my selection of these two photographers is that our subjects are all marginalised communities living in urban slums.

Starting from the late nineteenth century, socially-concerned documentary photographers like Jacob Riis harnessed the power of photography to expose certain pertinent issues which ought to be addressed. As a pioneer of urban photojournalism, Riis's intention was to expose the decrepit living conditions of the slum dwellers in order to advocate for social reforms. He had experienced poverty in the slums first-hand, thus it placed him in a better position to empathise with his subjects. He thought that the use

\footnotetext{
2 Historically a hinterland settlement founded by escaped slaves in Brazil, Quilombos represented areas of resistance and freedom for Brazilians of African descent as Brazil is the last country in the Western hemisphere
} to abolish slavery. 
of a camera, a revolutionary tool in his time, was the "most effective weapon in his arsenal against unsanitary tenement conditions" (Riis 1890, 82).

Riis adopted a guerrilla approach (he simply barged into people's homes in the middle of the night, scaring them with a flash). Taking an entirely different stance, Liste and I choose to immerse ourselves in a community for an extensive period of time in order to gain a better understanding of the subjects, their psyche and to forge closer bonds with them. While Riis's work served to illuminate issues that were hidden in the dark and gave faces and identities to marginalised communities who had been dehumanised into statistics, Liste's intention was to document Urban Quilombo and the inhabitants' resistance to a society that considered them as a dysfunctional organ.

Despite his success in promoting social change, Riis' method has its ethical ramifications concerning the intrusion of privacy. His guerrilla tactics of barging into the tenements in the middle of the night caught the inhabitants without prior warning. According to Riis $(1890,86)$, "the spectacle of half a dozen strange men invading a house in the midnight hour armed with big pistols which they shot off recklessly was hardly reassuring, however sugary our speech." Riis goes on further to tell us that it was so dramatic that some tenants bolted through windows and down fire-escapes.

While this sudden intrusion and capturing of the subjects totally off-guard in their natural setting sans staging may be regarded as candid, the magnesium flash powder Riis used often intimidated his subjects and exaggerated the actual appearances of the tenements. One could also argue that this approach actually undermined credibility since the subjects' appearances and gestures were more likely reactions to the harsh light from the magnesium flash powder. A more realistic documentation of tenement life might have been achieved if Riis had been more discreet in his style of working but given the technology which was available at that time, the use of a flash would have been no less 
intrusive. His concern for the downtrodden and dispossessed (homo sacers) living in the slums would have overridden the intrusive stance taken to photograph them.

On the other hand, Urban Quilombo resulted from a complete immersion with the community for two years as Liste visually captured the complexities of the relationships forged within the community in holistic ways. He has woven an intimate visual narrative which revealed how the inhabitants bonded through their common desire to tackle the problems of drugs, prostitution and violence. This mirrors my extended, immersive documentation of the plight of Palestinian refugees as they cope with the changes and dire living conditions in Shatila.

It is also noteworthy that my approach is non-interventionist, as the aim is to depict life and reality in Shatila through a documentary lens. As an observer who takes a photo when the moment is right, I wait until the point when the subject is engrossed in her/his thoughts or activities and is oblivious to my presence. The photos will then be taken, in what Henri Cartier-Bresson refers to as the decisive moment or "the simultaneous recognition, in a fraction of a second, of the significance of an event as well as of a precise organisation of forms which give that event its proper expression" (quoted in Tériade $1952,4)$.

4.2 Comparing the works of Sebastião Salgado and James Nachtwey vis-à-vis the documentation of Shatila Camp

In considering the works of both Sebastião Salgado and James Nachtwey, I have chosen them for the fact that all our works deal with refugees, the subaltern and marginalised people. The different approaches adopted by these two prominent figures in the photojournalistic world will be examined vis-à-vis the work I did in the Shatila Refugee Camp. 
In Salgado's depiction of famine refugees in the book Sahel (1986), which is the culmination of a fifteen-month long coverage of the drought in North Africa with (MSF) Médecins Sans Frontières (Doctors Without Borders), his approach is similar to that of an ethnographer's. Salgado immerses himself in the communities he works with which enables him to "nurture an empathy that allows him both privileged access and treasured invisibility" (Kay 2011, 425).

In photographing vulnerable people who are undergoing intense suffering, it is useful to look at how Salgado treats his subjects. Figures 43 and 44 show photos with people framed within a never-ending expanse of land in which their drama and trauma are cast, made possible by shooting with a wide-angle lens. Salgado's portraits of human pain are both evocative and visceral. They are set against panoramic backdrops which resemble paintings, instead of the standardised photos of starvation which depict victims with bloated bellies or flies in their eyes, pleading for aid. The subjects are endowed with a certain beguiling and reverential air. This is achieved by shooting from a low to medium-low angle as seen in both photos. As Salgado takes into consideration the height of the children, it clearly demonstrates the respect he accords his subjects, no matter what their ages are. He shows sensitivity towards their portrayal for to shoot from a high angle, that is to look down on subjects from a height, would result in a less than flattering depiction. This is something in which I am consciously aware of and try to avoid in my photographing of people, especially those who are marginalised in society.

Moreover, Salgado operates differently from news photographers. Instead, he undertakes long term, in-depth documentary projects as Eduardo Galeano states,

Salgado photographs people. Casual photographers photograph phantoms... Consumer-society photographers approach but do not enter. In hurried visits to scenes of despair or violence, they press the shutter... they shoot and run. They have looked without seeing and their images say nothing (Salgado et al 1990,1). 
While news photographers hop from one event to another, barely scratching the surface of the subject matter due to the fast-paced nature of their job, Salgado approached his projects through long-term engagements as he forged solidarity with his subjects. Salgado himself revealed that, "You must have a big ideological affinity with the subject, if you don't, you cannot remain sincere and empathetic for long. You must strongly identify with the subject" (quoted in Light 2010, 74). This is a precept in which I constantly adhere to, to produce works of compelling quality.

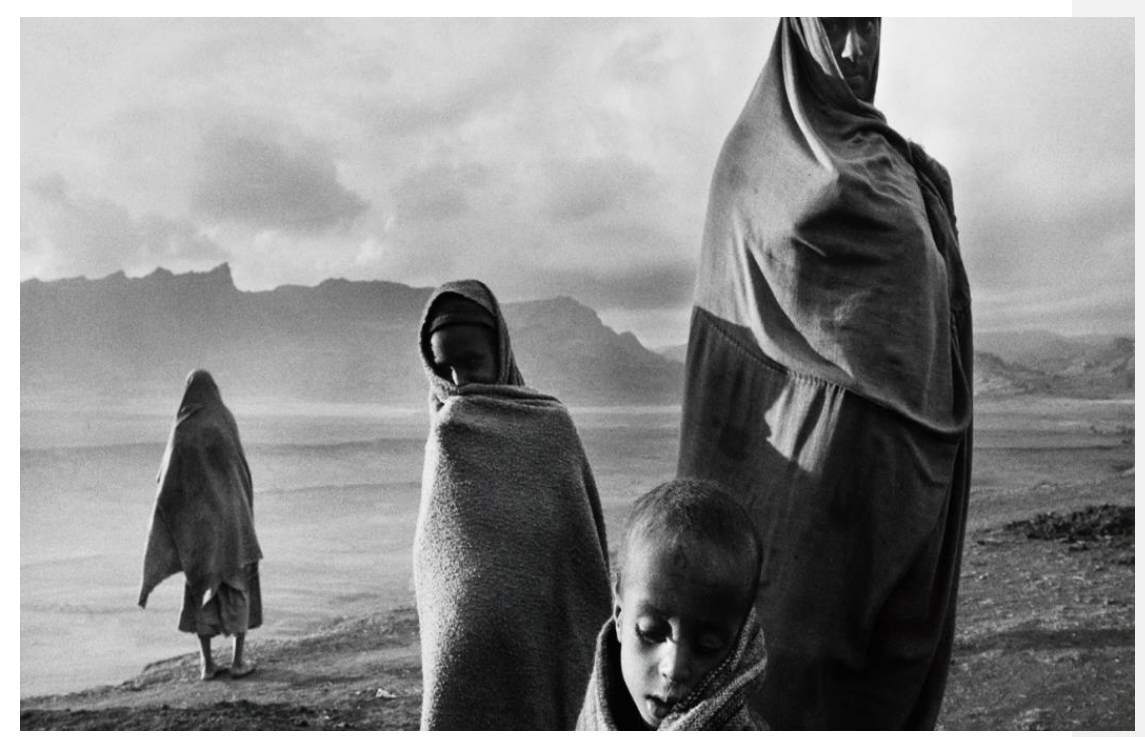

Figure 43. Sebastiano Salgado. Sahel - The End of the Road, Korem Camp, Ethiopia, 1984. 


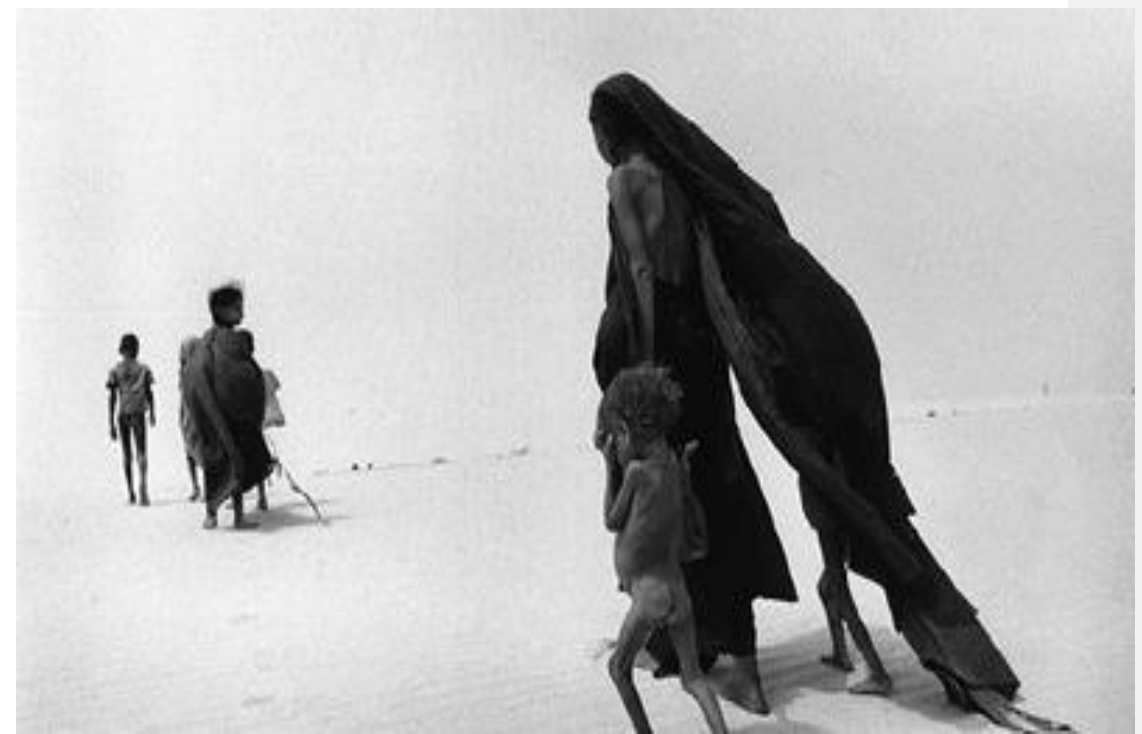

Figure 44. Sebastião Salgado. Sahel - The End of the Road, Korem Camp, Ethiopia, 1984.

In the face of adversity, Salgado chose to portray his subjects not with pity but to endow them with dignity which is indicative of the respect he has for them. In fact, the traits of dignity reverberate throughout Salgado's works (figures 31, 43 and 44).

In figure 31 , the surreal portraiture which resembles a painting depicts a woman in quiet contemplation. There is an aura of mystery and ethereal quality about this photo that is hard to define and she exudes a certain feminine strength despite her handicap and hardship. Through the adept use of the chiaroscuro effect, her right eye is partially covered by her veil and only her left eye which is blind is illuminated. The stark contrast in lighting highlights her blindness. Her condition which strikes one like an epiphany is made all the more hauntingly poignant as it was not immediately obvious that she was blind until one reads the caption. Salgado confers dignity to his subjects through his careful composition and use of natural light. However, he has been accused of aestheticising his subjects by creating beautiful works out of human misery instead of portraying them as helpless victims in need of aid from the first world nations i.e. the 
more affluent North. For my work, I chose to confer dignity to my subjects but the question of beauty is highly subjective for it lies in the eye of the beholder.

\subsubsection{Inferno by James Nachtwey}

In James Nachtwey's book Inferno, he dealt with similar issues of suffering in Africa. Selected images from this book will be examined and used as a contrast to Salgado's style. Nachtwey's searing documentation of the tragedy in the Sudan transports one directly to the crux of the matter. For he wants to confront the viewers and get them up close and personal to pain. His fiercely impactful photos are tightly framed and are devoid of superfluous details. This economical use of space in a frame certainly does not allow for the incorporation of the attributes of landscape, unlike Salgado's approach to the photo-documentation of the Sahel.

While Salgado's epic photos seem to afford a comfortable distance with his predilection for crafting a painterly background using the available landscape and light which can potentially distract, Nachtwey's incisive style brings one nearer to the gravity of suffering. His stance is to shoot at close range in order to convey a sense of immediacy and urgency to the viewers.

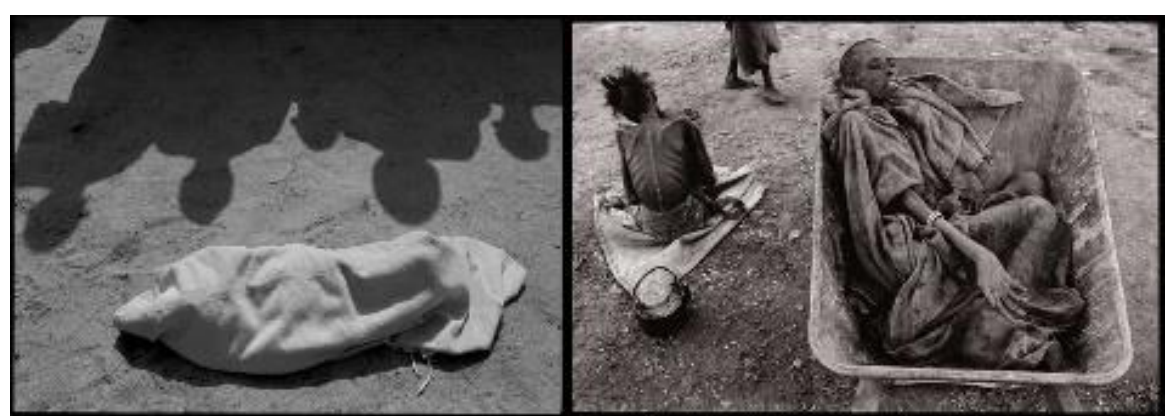

Figure 45. James Nachtwey, Inferno, 1999

Figure 46. James Nachtwey, Inferno, 1999 


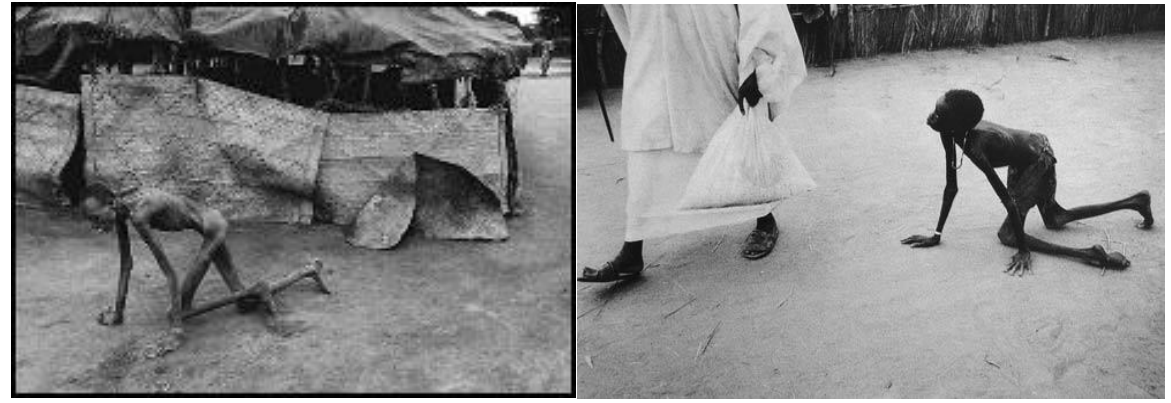

Figure 47. James Nachtwey, Inferno, 1999 Figure 48. James Nachtwey, Inferno, 1999

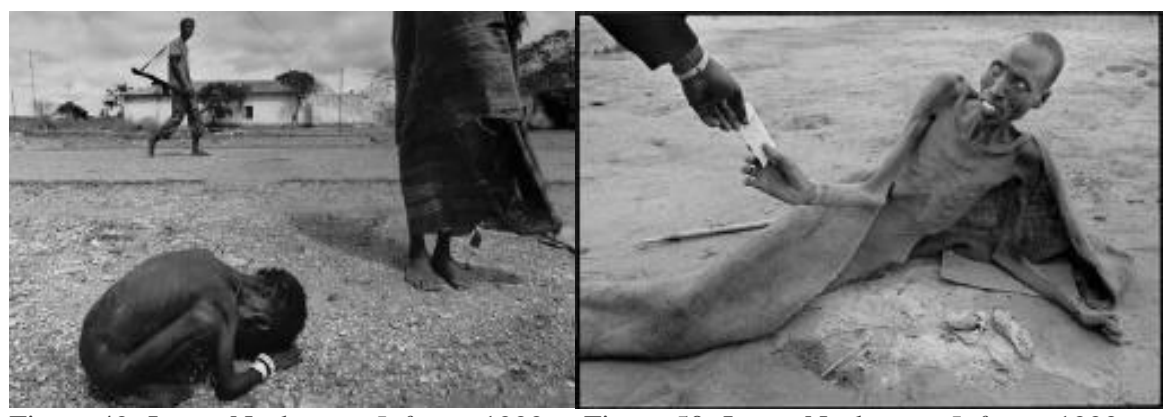

Figure 49. James Nachtwey, Inferno, 1999 Figure 50. James Nachtwey, Inferno, 1999

Nachtwey's compelling compositions serve to provide an unflinching record of the appalling crisis. With his minimalist style, the atrocities are depicted in striking black and white images which are intended to disturb our conscience. Nachtwey is "shaping pain, molding it into something (almost) recognisable in the hopes that we might receive it” (Linfield 2010, 214).

In figures 46, 48, 49 and 50, the deliberate omission of certain parts of the bodies from the frame is disconcerting yet riveting at the same time. It seems as if Nachtwey wants to stimulate the imagination of the viewers but this technique can also be regarded as dehumanizing to his subjects, by not showing them in their full form. Nachtwey wants the viewer to focus on what is most important by cutting off the superfluous elements in a frame. 
In these images (figures 45, 46, 47, 48 and 50), Nachtwey shot from a high angle, which gives a sense of someone looking down at the victims in a patronizing way. There are two ways to interpret this stance. Firstly, the high angle shot accords the viewers with a vantage point, suggesting power over the subjects. There is a possibility that some viewers may regard this mode of depiction as a form of condescension and subjugation. It carries the risk of humiliating and exploiting the subjects especially when their vulnerability is exposed for the world to see. Nachtwey's searing images of war and suffering are difficult to look at yet they are also voyeuristic in nature, in that the pain of the victims are exposed for the world to see. Secondly, the choice to shoot from a high angle could be a way of placing the viewer in the position of a victimiser. It could imply that the viewer plays a role in these atrocities and is implicated in a way that makes him/her take responsibility for what is happening. In short, Nachtwey wants us to be a witness to what he has seen and not look away.

Upon reflection, the high angle shot is an approach that Salgado and I hardly employ as it could evoke negative connotations. On the flipside, the low angle shot from a low vantage point accords power to the subject, with the impression that the subject is peering down at the viewers. To reconcile this ethical dilemma, the mid-angle shot is adopted by both Salgado and I. It is the most democratic of the three angles as it symbolises equality. The subjects are photographed almost at eye level with the photographer. This evenly 'distributes' the power relationship between the viewers and the subject. However, this does not imply that the high and low angle shots must never be used on photographing the subaltern. Nevertheless, it is useful to appreciate the impact that different angles will bring when shooting so that a photographer can make informed choices and avoid unintended consequences or the misinterpretation of intentions. 
Another key difference between Nachtwey's and Salgado's style is that the latter has a gift for harnessing the beauty of light. This in turn endows his subjects with dignity and beauty which could potentially elicit sympathy. "I wanted to respect the people as much as I could, to work to get the best composition and the most beautiful light" (quoted in Stallabrass 1997, 19). This concept is akin to how the iconography of Christ's crucifixion has long been aestheticised in Western art as a way of acknowledging and ennobling Christ's pain and sacrifice.

In summation, the key factor that distinguishes my work from both Salgado's and Nachtwey's is that a particular subject, Zeinab and her family has been chosen as a representative for closer study that provides deeper insight into life in Shatila. In the works of Salgado and Nachtwey analysed in this paper, there is no evidence of any focus on a particular subject for in-depth documentation. It was mainly a visual record of issues more in the style of photojournalism. While Nachtwey's work is more inclined to press photography, Salgado's style tends more towards fine art. To avoid the pitfall of seeing life in Shatila through a tunnel vision of just one subject and her family, it is important to extend the coverage of life in the camp to its environs as well. I am also aware of and I acknowledge that my portrayal of the camp residents can never be complete since I have only focused on one woman and her family which provide rich information. It is beyond the scope of this thesis to cover more families.

The common trait that Salgado, Nachtwey and I share is that we are all foreigners documenting the lives of marginalised people. With noble aims from shedding light on humanitarian issues to giving voices to the subaltern, it is important to be mindful of how our mindset, cultural background and ideologies can shape the way we view our subjects. From the viewpoint of Lévinasian ethics, photographers who normally come from a more privileged background should exercise sensitivity when dealing with the less fortunate. 
As we are taking on a responsibility for these people as the other and how that other is perceived. A necessary step to take in portraying the subaltern in a morally responsible way is to consciously preclude bias and preconceptions related to Orientalism in the process of photographing.

4.3 Ethical considerations regarding the visual portrayal of Shatila Camp

This chapter is a reflection of my documentation of the life and residents of Shatila Refugee Camp over the past 6 years. Having done a literature review of the photographic works on the camp based on the archives of major photo agencies, as well as an analysis of salient paintings and images which manifested elements of Orientalism, a consolidation of some ethical concerns and pitfalls which surfaced will be addressed as follows. Best practices which are aimed at minimising the impact of the photographer on this vulnerable community of people will also be explored.

The discoveries of recurring themes and stereotypical images of the camp encouraged me to rethink and reconsider different ways of portraying the life and residents of Shatila in a more comprehensive manner, without shying away from its realities and problems. Unlike photojournalists on assignments with tight deadlines to meet, I am not limited by time or editorial constraints so I can delve much deeper into camp life and concentrate on producing a substantial body of work.

From my observations of Shatila over the past six years, there are many drastic spatial and demographic changes which ought to be documented. With the ongoing influx of war refugees from Syria, Palestinians living in Shatila are further marginalised within their own space as the population swelled from about 10,000 in 2010 to about 22,000 in 2016. These physical changes were captured from my documentation of the camp over time as apartment buildings expanded vertically within the same fixed space allocated to host the refugees since 1949. 
Other than focusing on the sensational or exceptional events in the camp, it is also essential to document the daily lives of the camp residents. The challenge is to create compelling images out of mundane activities such as cooking or working etc. The aim is to humanise these refugees, that even though they may be stateless, they still try to lead normal lives. Time spent in the camp with efforts made to establish rapport with the residents will help ease access into their homes, a private and intimate space, to photograph.

The images produced - semblances of what a typical family life is like at home would help to bring the viewer closer to the subjects instead of persistently portraying them going through a crisis e.g. the aftermath of a massacre which could further distance the camp residents from the viewer.

\subsubsection{The ethical role of a photographer}

The photographer will always have the upper hand for s/he is the one who makes the decision on how the subjects will be portrayed, thus elevating her/him to a position of relative superiority over that of his subjects. The documentation of the lives of subjects is a complex process filled with ethical quandaries and this is especially pronounced when the subject is a refugee in a vulnerable position. In general, a photographer tends to be an outsider from a more privileged background in comparison to the refugees living in camps, thus there is inherently, in the images produced, an unequal power relationship.

As the privileged one who owns and operates the camera, the photographer holds a power over the subject. Being the professional who knows how to handle the equipment, I am in complete control over how I want to frame my subjects whose representation lies solely in my hands. As Sontag $(1977,4)$ says, "To photograph is to appropriate the thing photographed. It means putting oneself into a certain relation to the world that feels like knowledge - and, therefore, like power." Therefore, the power of 
representation rests heavily upon the shoulders of the photographer as s/he treads along fine ethical lines while trying to convey humanitarian messages to the public.

\subsubsection{Empathy and Responsibility}

Tied in closely with the notion of power comes responsibility. To be responsible for the other is a core tenet of Lévinas' philosophy. In the Conversations with Phillipe Nemo, Lévinas says that "the proximity of the Other is not simply close to me in space, or close like a parent, but he approaches me essentially insofar as I feel myself—insofar as I am—responsible for him" (quoted in Nemo 1985, 97). To extend his point further, we exist and are defined by the other to whom we owe a debt that cannot be repaid and thus bear a responsibility for. The subjective self is defined by a relationship with the other as the non-self, the pre-original.

Lévinas' concept of responsibility for the other has a significant resonance with how we encounter the marginalised. Therefore, in the interaction between a photographer and her/his subjects, ethics defines the way in which the former should relate to the latter. The key idea is that one should place the other before oneself and consider her/his existence more important than one's own. Due respect for the comfort, security and dignity of the subjects must be accorded as they have magnanimously given the photographer the access into their private lives. It must be regarded as a privilege and these subjects must never be harmed. This is even more significant for refugees who are already in a vulnerable state (Levinas 1998, 74).

In order to enhance the portrayal of the subjects, the photographer can try to put herself/himself into the shoes of the other i.e. the subjects. For it is this concept of 'substitution' that could enable the photographer to empathise more fully with the subjects. Thus, within the ethical framework of Lévinas, it is incumbent upon the photographer to be responsible for the subject, and be mindful that their well-being 
overrides that of the photographer's. This ethical concept is so fundamental and strong in dealing with the subjects such that Lévinas refers to it as "the tie with the other is knotted only as responsibility" (Lévinas 1985, 97).

\subsubsection{Photographing daily life in Shatila Camp}

The first impression one gets when one enters Shatila Camp is a scene of chaos with water hoses and electricity wires hanging loosely from across apartment buildings. With a population of about 22,000 living within a tight space of one square kilometer, it is common to find motorbikes trying to negotiate their way around the camp as they jostled with human traffic passing through the narrow lanes. The constant power cuts have forced some residents to sit outside on the ground floor especially in the hot summer months. Many jobless youths are seen smoking their time away on water pipes (locally referred to as "hubbly bubbly or shisha") and kids milling around as vehicles and push carts selling shoes, fruits or vegetables try to avoid them.

While fast-paced actions such as people running around with rifles typically requires one to take photographs quickly in a reportage style reminiscent of spot news photography, I also take photos of a slower and more contemplative nature where people try to find space and privacy in hidden corners and rooftops in this severely overcrowded camp. This is to highlight that in the midst of chaos, people do try to seek inner peace in nondescript places. In some of the images, the residents of Shatila seem to be lost in their own world and appear to be in states of suspended animation, waiting, staring (figure 51) and smoking. People normally do not meet my gaze as I capture them in unguarded moments. If they were to notice my presence, the moment of authenticity would vanish as they would then be reacting to me, as a foreign photographer. This is in adherence to the tenets of photojournalism in which the photographer tries to adopt the fly-on-the-wall approach and not interfere or influence the situation. 


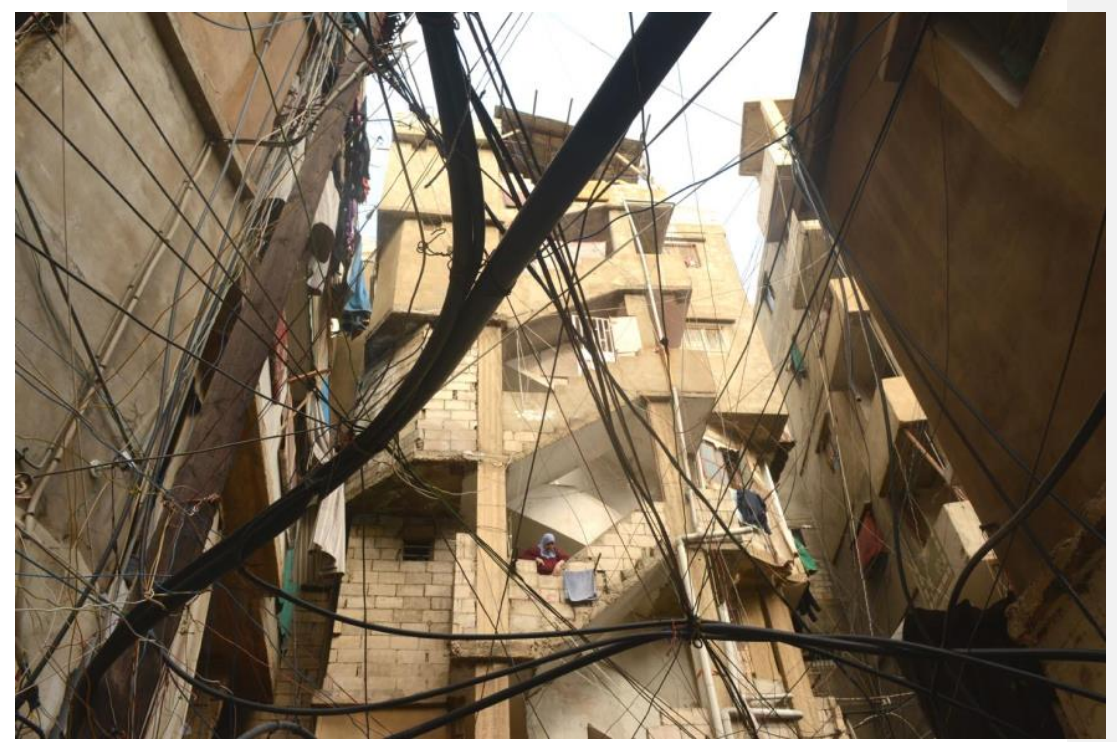

Figure 51. Zann Huizhen Huang. Shatila Camp, 2012

\subsubsection{Stereotyping Palestinian refugees}

The typical portrayal of the residents of Shatila is as constantly sitting, waiting, smoking or even carrying weapons, if they work for Fatah since the unemployment rate in this camp is high (UNWRA 2016). There is a risk of perpetuating the stereotype of these refugees as being dependent on aid and not taking the initiative to look for jobs or behaving like violent gun-toting thugs. While this symbolises a community in stasis, I am also in peril of treading on the very thin and nebulous line of typecasting the refugees as a passive people waiting for the 'right of return' to their homeland. This apparent passivity is actually a result of labor restrictions applied on Palestinian refugees in Lebanon and their lack of civil and social rights (Hanafi et al 2012, 34), hence the unemployment rate is high.

Thus, I shoulder a heavy responsibility in the representation of Palestinian refugees (homo sacers). To avoid the minefield of relegating them as a 'special' category of people looking to the world for a solution to their statelessness. I sought ways to negotiate this 
delicate issue. To redress this imbalance, I tried to portray the camp residents differently, to depict them as people with agency. In fact, it is the marginalisation of this community in Lebanon which gave rise to their resilience and resourcefulness. The camp residents have managed, against all odds to fuel a self-sufficient economy within the camp.

\subsubsection{Turning subjects into symbols}

In the process of taking photographs, the act of framing is inherently an aesthetic choice as the photographer mediates and captures what transpires before her/him. According to Gross $(1988,22)$, "the artist is often regarded as being somewhat outside the moral constraints which confine other people; having license to transform people into aesthetic objects without their knowledge and sometimes against their will... Because of this, even photographic art has political and ideological content."

Pertaining to 'socially concerned' photography, which is specifically the genre of photography at stake here, will the aestheticisation of issues and subjects doubly victimise the subaltern? There is a risk of transforming the subjects into symbols. There are some historical examples to draw from such as Dorothea Lange's The Migrant Mother and The Afghan Girl by Steve McCurry. When both photographers took these photos, little did they expect their images to assume lives of their own and become iconic. The Migrant Mother symbolizes strength in the wake of the Great Depression while The Afghan Girl's haunting green eyes became the windows into the souls of thousands of Afghan children who had suffered years of hardship due to war and conflict. The common irony and unintended consequences are that these two images became cult symbols, bringing fame to the photographers. The subjects themselves did not reap the same benefits. In fact, the woman in the The Migrant Mother resented the image as she was rendered as a symbol of a group of displaced people that she was not a part of. Finally identified years later as Florence Thompson, she is "bitter, angry, alienated not so much 
by her past as a migrant worker but by the commodification of her image that completely divorced the woman in the photograph from the living Thompson" (Hariman and Lucaites 2007, 53-67).

To mitigate the negative impacts of such turnout of events, the least that a photographer can do is to find out the name and background of the subject and not make assumptions in the writing of captions which might mislead the viewer. In short, the key is to be responsible and practice good journalism.

\subsubsection{Ruin Porn? - Photographing the architectural ruins of Shatila Camp}

The intention of photographing the ruins in Shatila as part of my documentation was to show the living conditions and physical environment of the camp. Over the past six decades, Shatila has witnessed and endured various violent ordeals such as the Lebanese Civil War (1975-1990), the War of the Camps (1985-1988) as well as the infamous Sabra-Shatila Massacre in 1982. These episodes cast dark shadows over the camp as their legacies manifest themselves in the form of crumbling buildings and bulletridden walls (figure 52). This scenario of stagnation and deterioration is in sharp contrast to the rest of Beirut where reconstruction was rapid following the post war years in the 1990s, as swanky new apartment buildings line the coasts of the Mediterranean Sea in areas such as Ras Beirut. 


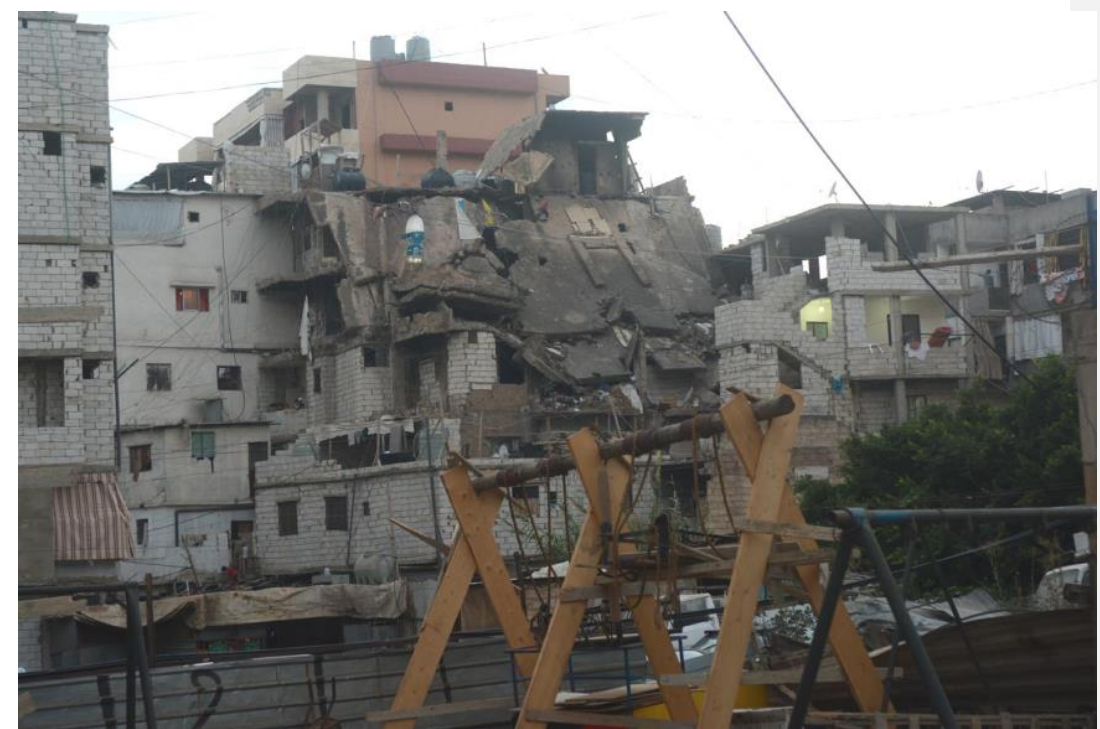

Figure 52. Zann Huizhen Huang, Shatila Ruins, 2012

In this section, I will examine the moral ramifications of photographing destroyed buildings and urban decay. Known as Ruin photography or Ruin porn, it is defined as a "superficial, one-eyed portrayal of urban decay that ignores its socio-political causes and consequences" (Pétursdóttir and Olsen 2014, 9). Apparently coined by the natives of Detroit, the term "ruin porn" is a "critical response to artists', photographers' and journalists' alleged growing exploitation of the city's ruination... to signify a speculative and distorted imagery that at the same time is alluring and seductive, a ready-made commodity issued for instant pleasure and consumption" (Pétursdóttir and Olsen 2014, 9).

With its preoccupation with the aesthetics of modern urban decay, this term is heavily laden with seedy connotations and has been accused of being exploitative in nature. A prominent duo who exemplify this artistic form are Yves Marchand and Romain Meffre. They created visually striking images of the urban decay of Detroit, glamourising its ruins. This act could be regarded as a double-edged sword as it could 
trivialise the causes of urban decline by glossing over pertinent socio-economical issues with stunning images. On the other hand, it could also spark off debate, dialogue and reflection.

In the context of a highly-politicised space like Shatila Camp, I will consider how sensitive it is to photograph the chaotic terrain of the camp space which has been stereotyped as urban decay with bullet-ridden buildings. The very act of trying to compose striking images out of destroyed buildings raises questions of ethical concerns. It has been difficult to reconcile this dilemma; that I was creating 'art' at the expense of someone else's pain and loss. How does one create images without exploiting the ugly and bloody history of Shatila?

Instead of dwelling on how images of ruin could potentially be fascinating, perhaps, it will be more constructive to question the purpose they serve. By regarding images of devastation at face value, bereft of any sort of historical context, one runs the risks of seeing just the form and gaining no new insights or knowledge of the situation. Images of ruins in Shatila are more than just old, crumbling buildings but are a living testament to its violent past. The ruins also speak volumes about the lack of status of the Palestinians, as homo sacers, who live in the periphery of Lebanese society. While images of decay in Shatila might seem to hint at a broader failure of the Palestinians to improve the infra-structure of the camp, the actual reason lies in Lebanese legislature, according to Jaber Suleiman who wrote in a paper for the Development Research Centre on Migration, Globalisation and Poverty $(2006)$. Suleiman $(2006,19)$ states that it was actually the restrictions imposed by the Lebanese Army and successive governments which prohibited the reconstruction of Palestinian refugee camps, thus exacerbating their living conditions. On the other hand, the camp space may be regarded as a temporary space as the residents hope for a better life elsewhere, as they struggle to be upwardly 
mobile, or retain the idea of being able to return to Palestine. All these forces have caused the camp to be left in a state of neglect.

While there is no control over the reception of these images, whether the viewer will be captivated by the allure of destruction or glean more information. The crux of the issue is that these images should provoke our engagement. Images as such are didactic and serve as reminders that such a history (war and violence) should not be repeated again. Lastly, it is also important to photograph responsibly by putting images into context or weave a narrative using a photo-essay structure with captions.

\subsubsection{Symbols of Palestine}

With little hope of ever returning to Palestine, Shatila became as a space where Palestinian refugees could nurture their sense of identity and build national consciousness. Being a marginalised group in Lebanon, Shatila is not only a space of refuge but a special enclave, which Sari Hanafi $(2008,86)$ refers to as a "state within a state." It is also a space of memories where Land Day, Al-Nakba day and the anniversary of the Sabra-Shatila massacre are commemorated.

Enter Shatila and one will be greeted by insignias of Palestine such as the national flag, the flags of Fatah and Hamas, banners of martyrs and political leaders such as the late PLO leader Yasser Arafat. The topography of Shatila is characterised by graffiti on the walls of buildings depicting Al-Quds (Jerusalem), Handala, martyrs of the resistance such as Leila Khaled, anti-Israel drawings, prominent Palestinian rights activists such as Rachel Corrie, Palestinian Dabke dances, the Keffiyeh and numerous Arabic inscriptions. These expressions of a longing for Palestine inevitably transformed Shatila into a politicised landscape. Art as a form of cathartic expression, is regarded as a collective mouthpiece especially for these people who had been 'silenced' by the larger Lebanese 
society. Therefore, it is imperative to include these visual symbols as part of the documentation of life in Shatila Camp.

The ethical implication pertaining to the documentation of these symbols is the risk of politicising the camp. Moreover, one needs to be mindful of the frequency of showing photos of Fatah or Hamas as it is important to find a balance and avoid giving more attention to either party which could result in the misrepresentation of the political situation of Shatila. There are some camp residents, both Palestinians and nonPalestinians alike, who are apolitical and prefer to sit on the fence. Yet, there is no way to avoid covering politics in this camp as it is a highly-politicised place based on its history.

\subsubsection{Privacy and Intrusion}

While the photographing of people in public spaces may be legal, the parameters change when the photographer crosses the boundary into the private domain of a subject. Therefore, ethical concerns arise and permission needs to be given. When documenting a subject's life, it can be regarded as intrusive. As there is a potential that the camera can become a prying tool as one gets intimate, up close and personal with the subject. This includes instances when photographers may unconsciously or inadvertently intrude inappropriately upon their subjects' privacy such as in Zeinab's case where her abode lies just next to the sewing machine placed on the lane where she works. 


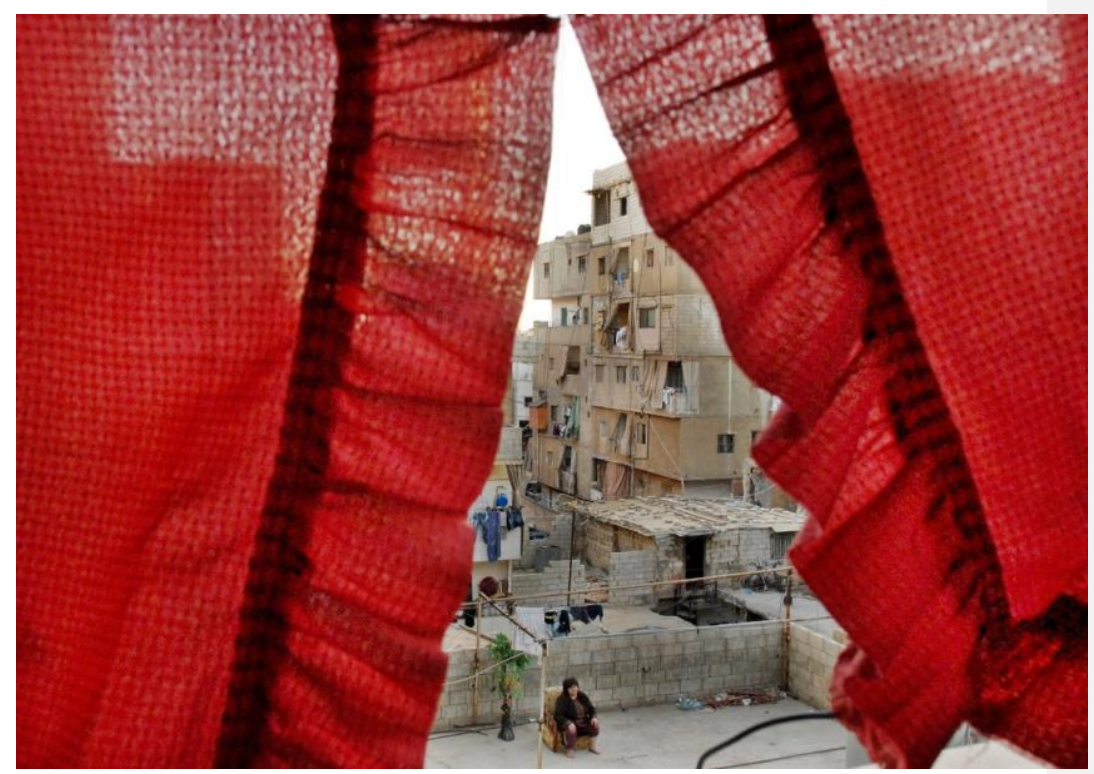

Figure 53. Zann Huizhen Huang, Shatila Camp, 2012

In figure 53, a woman is seen sitting on a sofa on the rooftop of a building. By shooting through a pair of red curtains, it renders the scene like a stage. This is symbolic of how the image is like a window through which one can peek into others' lives. In Shatila Camp where the buildings are constructed in close proximity, sometimes just one meter apart, there is an ethical risk of becoming voyeurs as one takes photos from a comfortable distance without the knowledge of the subject(s). However, it is not against the law if one were to photograph in public space.

\subsubsection{Immersion in Shatila Camp}

It is also vital that I bear witness to and portray the subject(s) in the most accurate light possible. As this is not a quantifiable attribute, one has to rely on one's judgement and integrity to prevent the deliberate distortion of truth through framing and captioning. It is incumbent upon the photographer to be truthful to the public, to be fair and just to the portrayal and integrity of the subject(s) while trying to fulfil one's artistic vision 
simultaneously. Adhering to the tenets as laid down by the NPPA (see Appendix 2, the NPPA Code of Ethics), the photographer should never interfere with the flow of events and manipulate the subjects or events.

In order to visually represent the subject(s) with clarity and precision, it will be ideal to spend enough time and be immersed in their world. Not only can a photographer develop a closer rapport and understanding of their lives, trials and tribulations, s/he can also gain a better understanding of their culture and lifestyle. This process would help to mitigate any preconceived notions that a photographer might have, which could subconsciously color his/her perception of the subjects. In doing so, this could minimise her/his bias which might be prescribed onto the final images produced.

Moreover, the engagement on a deeper level and the immediacy as felt by the photographer can then be better transposed onto the images produced. This will in turn give the viewers a more intimate and accurate understanding of the psyche and lives of the subjects being portrayed. It does not only serve ethical purposes but also do justice to the subjects, by portraying them as accurately as possible. Thus, reinforcing the central tenets of Lévinas' ethical stance on responsibility for the other, especially in relation to the subaltern.

\subsubsection{Personal Vision versus Bias}

When a photographer and her/his subjects develop a strong bond, what is termed as researcher bias (used in social science), may set in which blurs the distinction between objective and subjective reporting. As human beings with emotions, being subjective is inevitable. We are not impassive machines; thus, it is inevitable that the framing of our photos is shaped by how we think, feel and react. Since self-expression is unavoidable, the crux of the matter is how skillfully photographers can negotiate their emotions within documentary photography. How can a photographer achieve balance between truth and 
objectivity, responsibility for the subjects and the photographer's personal vision? Can a photographer's emotions and personal vision enhance and engage the viewer's attention or does it serve to distract them from the issues at stake? Must one compromise one's aesthetic expression to attain ethical and political authenticity? Where can the boundary be drawn? What are the ethical implications? Tamara Kay $(2011,426)$ mentions that, "documentarians and sociologists are driven by a common methodological goal: to provide an analysis unsullied by bias, politics, or self-interest." For the viewers, this can mean being given deeper insights into the issues of concern than if a photographer was detached from her/his subjects.

\subsubsection{The Moral Choice}

In taking photographs of subjects who are suffering, James Nachtwey's work on war and hunger in the Sudan opens the door to critical moral discussions. How can a photographer look at the misery before him and have the emotional and ethical capacity to compose aesthetically compelling images? Would this not cast him as exploitative or even as a voyeur of someone else's pain? What would the alternative be? Should Nachtwey put his camera down and help the victims? This is a crucial point in which he has to make a moral choice. As a professional photojournalist, it is his duty to present to the world what he has witnessed, with due faith that the power of his images will have more everlasting impact.

Hence, after considering the impact of photographing this vulnerable group of people in Shatila Camp, the verdict lies in favor of using photography to shed light on the pertinent issues of the camp. For it is still a better option than to ignore the situation and let it fester. Ultimately, the key point is to be always mindful of how one's actions will affect the residents. 


\subsection{Conclusion}

By unravelling the threads of Orientalism that have infiltrated and influenced the visual arts, one gains a deeper understanding of not just how tenacious these traits are but how much distortion it has generated over time. This is reinforced by Said who quoting Barthes in his book, Orientalism says that "a myth (and its perpetuators) can invent itself (themselves) ceaselessly" (quoted in Said 1979, 308). In fact, these misconceptions run so deep that even though the Orient does not physically exist, the region can and has been culturally dominated and colonised by an Occident which seemingly deemed itself more superior. This is a colonialism of the mind both inside and outside of the Orient.

Analysing paintings and photographs from the Orientalist tradition allows one to discover how skewed the portrayals were, and that the continued unintended consequences can be detrimental to the image of not just an individual but to an entire imaginary region, i.e. the Orient. While the influences of Orientalism on paintings and photography may be immaterial, its impact can be highly potent as images speak a thousand words.

The acknowledgement of how deeply ingrained and influential Orientalist concepts have on visual art works could pave the way for greater awareness for both the artists and the audience. The former should be aware of the effects of Orientalism in her/his practice. This is why a careful study of Orientalist traits in the works of other contemporary photographers plays an important role in guiding my photo-documentation of the residents of Shatila Refugee Camp. It helps inform me in seeking an ethically responsible way of working.

As Edward Said $(1979,328)$ says, "Orientalism failed to identify with human experience, failed also to see it as human experience." This powerful statement urges one to try to empathize with the subaltern, especially in the case of photographing vulnerable 
people such as refugees. To develop empathy, spending time to get to know and understand one's subject(s) is crucial in depicting them in the most comprehensive and accurate way possible. Hence, long term documentary photography is the ideal tool for me to document the life and living conditions of Shatila Camp. By extension, the images produced will hopefully foster a much healthier inter-cultural understanding, in what Said $(1979,28)$ calls "a new kind of dealing with the Orient, indeed if it eliminates the 'Orient' and 'Occident' altogether, then we shall have advanced a little."

Last but not least, the philosophical tenets of Lévinas have been useful in underpinning how one, whether as a photographer or not, should treat the other with the utmost respect and humility.

\subsubsection{Limitations}

The current study has several limitations. First of all, it goes in tandem with the “methodological failures" acknowledged by Said $(1979,322)$ himself, in that the "real Orient is necessarily different from the Orientalists' impressions of it" and that "since Orientalists are Westerners for the most part, they cannot be expected to have an inner sense of what the Orient is all about. Both of these propositions are false." Indeed, one should not assume that just because a photographer is from the West, her/his works would certainly be Orientalist in nature. And that only a photographer from the Orient should be justified in documenting the region where s/he comes from, based on his/her inherent cultural understanding of the Orient.

Secondly, the paintings and some photographs examined were produced almost two centuries ago. Many of the painters had never even stepped into the Orient and had created works based on their imaginations. Times have changed and the world is more globalised than it has been before. People from different nations and cultural 
backgrounds have travelled and interacted more with one another, resulting in more exchange of ideas.

Lastly, as photojournalists document the events which transpired before them, one must exercise caution in jumping to the conclusion that any image which exhibit traits of Orientalism must necessarily be products of the photographer's skewed vision of the Orient. Deeper analysis could be conducted in the use of Orientalist tropes in fine art or photojournalistic practice, but it is beyond the scope of this current thesis.

\subsubsection{Suggestions for further study}

More in-depth research could be done in the area of the analysis of photographs of Shatila from various photo agencies, but that is beyond the scope of this research. It is recommended that future researchers adopt a mixed method research by incorporating quantitative methods alongside the qualitative methods used here. For instance, one can break down the archives of photo agencies into different categories for analysis such as:

1. Number of images taken of the Sabra-Shatila Massacre

2. Number of images of women mourning over victims of the Sabra-Shatila Massacre

3. Number of images of Shatila Camp conditions

4. Number of images which depict how the residents live inside their home

5. Number of images which portray camp residents in affirmative roles

6. Number of images where the subject is identified and his/her story told in the captions

7. Number of images taken by a photographer from the Orient or the Occident, including the gender of the photographer

These are some suggestions which will require more refinement but the findings will certainly unlock further details about how Shatila has been portrayed throughout the 
years. Further study can also be done on whether editorial control and industry standards

and demands play a role in how photographers frame their images to suit a certain market. 
Bibliography

Abbott, Brett. 2011. Engaged Observers: Documentary Photography since the Sixties. Photography and Culture 4, no. 3, p371-76.

Abu-Lughod, Lila. 1998. Remaking Women: Feminism and Modernity in the Middle East. Princeton Studies in Culture/Power/History. Princeton, N.J: Princeton University Press.

Agamben, Giorgio. 1998. Sovereign Power and Bare Life - Homo Sacer. Stanford, California: Stanford University Press.

Ali, Sadaf Rashid, Debbie James and Fred Vultee. 2013. STRIKE A POSE: Comparing Associated Press and UNICEF Visual Representations of the Children of Darfur. African Conflict and Peacebuilding Review. Issue 3, Vol. 1, Spring 2013. Indiana University Press.

Archer, Isabella. 2010. “(Re)Envisioning Orientalist North Africa: Exploring Representations of Maghrebian Identities in Oriental and Occidental Art, Museums, and Markets," intersections Vol. 11, no. 2: 67-107.

Ataman, Joseph. 2015. "Renting on Lebanon's black market with rent prices sky high, Syrian tenants are paying the price." Executive-magazine.com, June 3, Business and Finance Section, accessed 16 Feb 2017

http://www.executive-magazine.com/business-finance/real-estate/renting-on-lebanonsblack-market

Avedon, Elizabeth. 2014. New York: Rania Matar Talks To Elizabeth Avedon. L'oeil de la Photographie. June 29, United States, accessed 11 Jan 2017. http://www.loeildelaphotographie.com/en/2014/06/29/article/25231/new-york-raniamatar-talks-to-elizabeth-avedon/

Barthes, Roland. 1977. Image, Music, Text (in Translation from the French). London: Flamingo.

_ 1981. Camera Lucida: Reflections on Photography. Hill and Wang.

Behdad, Ali and Gartlan, Luke. 2013. Photography's Orientalism: New Essays on Colonial Representation. Published by Getty Research Institute.

Bloom, Kelly. 2004. Orientalism in French $19^{\text {th }}$ Century Art, Boston College University Electronic Thesis and Dissertations, accessed 18 Jan 2017. https://dlib.bc.edu/islandora/object/bc-ir:102288/datastream/PDF/view

Chapnick, Howard. 1994. Truth Needs No Ally: Inside Photojournalism. University of Missouri.

Cramerotti, Alfredo. 2009. Aesthetic Journalism: How to Inform without Informing. Intellect Ltd. 
Demos, T. J. 2013. The Migrant Image: The Art and Politics of Documentary during Global Crisis. Durham, London: Duke University Press.

Elkins, James. 2011. What Photography Is. New York: Routledge.

Emerling, Jae. 2012. Photography: History and Theory. Abingdon, Oxon; New York, NY: Routledge.

Georgiou, Myria. 2006. Diaspora, Identity, and the Media: Diasporic Transnationalism and Mediated Spatialities. Cresskill, N.J: Hampton Press.

Gross, Larry, John Katz Stuart and Jay Ruby. 1988. Image Ethics: The Moral Rights of Subjects in Photographs, Film, and Television. New York: Oxford University Press.

Grady, John. 2008. Visual Research at the Crossroads. FORUM: QUALITATIVE, SOCIAL RESEARCH, SOZIALFORSCHUNG. Volume 9, No. 3, Art. 38.

Hanafi, Sari and T Long. 2008. "Palestinian Refugee Camps in Lebanon: Laboratories of State-in-the-Making, Discipline and Islamist Radicalism." Ronit Lentin. London: Zed books, 82-100.

— Jad Chaaban and Karin Seyfert. 2012. Social Exclusion of Palestinian Refugees in Lebanon: Reflections on the Mechanisms that cement their persistent poverty. Refugee Survey Quarterly, Vol. 31, No. 1, pp. 34-53.

Hariman, Robert and John Louis Lucaites. 2007. No Caption Needed: Iconic Photographs, Public Culture, and Liberal Democracy. Published by the University of Chicago Press.

Heron, Liz and V. Williams. 1996. Illuminations: Women Writing on Photography from the 1850s to the Present. Duke University Press.

Jacobson, Ken. 2007. Odalisques and Arabesques: Orientalist Photography 1839-1925. London: Quaritch.

Jhally, Sut. 2005. Transcript of interview with Edward Said On 'Orientalism'. University of Massachusetts-Amherst, Media Education Foundation, accessed 19 Jan 2017. http://www.mediaed.org/transcripts/Edward-Said-On-Orientalism-Transcript.pdf

Kay, Tamara. 2011. Building Solidarity with Subjects and Audience in Sociology and Documentary Photography. Sociological Forum, Vol. 26, No. 2, June 2011, accessed 6 July

2016.

http://scholar.harvard.edu/files/tamarakay/files/kay_sf_article_2011.pdf

Khatib, Lina. 2013. Image Politics in the Middle East: The Role of the Visual in Political Struggle. London: I.B. Tauris.

Lévinas, Emmanuel. 1979. Totality and Infinity: An Essay on Exteriority (in Translation of: Totalite et infiniti). The Hague, London: Nijhoff. 
1985. Ethics and Infinity: Conversations with Philippe Nemo. Translated by Richard Cohen. 1st ed. Pittsburgh: Duquesne University Press.

1998. Entre Nous. Translated by M. B. Smith and B. Harshav. New York: Columbia.

Light, Ken. 2010. 2nd Revised Edition. Witness in Our Time, Second Edition: Working Lives of Documentary Photographers, Published by Smithsonian Books.

Linfield, Susie. 2010. The Cruel Radiance: Photography and Political Violence. Chicago: The University of Chicago Press.

Lyotard, Jean-François. 1988. The Differend: Phrases in Dispute. Theory and History of Literature. Minneapolis: University of Minnesota Press.

Mackenzie, Laura. Correspondent. January 14, 2016. Shatila's population unknown as* Palestinian refugee camp bursts at seams. The National, Accessed 25 Jan 2016. http://www.thenational.ae/world/middle-east/shatilas-population-unknown-aspalestinian-refugee-camp-bursts-at-seams\#page2

Malkki, Liisa. H. 1995. Purity and Exile: Violence, Memory, and National Cosmology Among Hutu Refugees in Tanzania. Chicago: Chicago University Press.

1996. Speechless emissaries: Refugees, humanitarianism and dehistoricization. Cultural Anthropology 11: 377-404.

Matar, Rania. 2009. A Girl and Her Room: Project Statement. Personal Website, accessed 18 Jan 2017.

http://raniamatar.com/portfolio/girl-and-her-room/index.php

Mauro, Alessandra and Susie Linfield. 2007. My Brother's Keeper: Documentary Photographers and Human Rights. Rome: Contrasto; London: Thames and Hudson.

McCurry, Steve. 2001. "National Geographic: Afghan Girl, A Life Revealed". The Washington Post. April 10, accessed 25 Jan 2017.

http://www.washingtonpost.com/wp-

srv/liveonline/02/world/world_mccurry041002.htm

Mehdid, Malika. 1993. "Tradition and Subversion: Gender and Post-Colonial Feminism, the Case of the Arab Region" (with Particular Reference to Algeria). (Electronic Resource). University of Warwick, accessed 8 June 2016. http://wrap.warwick.ac.uk/34641/

Md. Mahmudul, Hasan. 2005. The Orientalisation of Gender. The American Journal of Islamic Social Sciences 22:4, Vol 22, No.4, Fall 2005.

Moeller, Susan D. 1999. Compassion fatigue: how the media sell disease, famine, war, and death. New York; London: Routledge.

Newhall, Beaumont. 2009. The History of Photography: From 1839 to the Present. 5th ed., 11th printing, completely revised and enlarged edition. New York: Museum of 
Modern Art.

Nochlin, Linda. 1989. The Imaginary Orient - The Politics of Vision: Essays on Nineteenth-Century Art and Society. Harper and Row.

Pasin, B. 2014. A Critical Reading of the Ottoman-Turkish Hammam as a Representational Space of Sexuality, unpublished $\mathrm{PhD}$ dissertation, Middle East Technical University, Department of Architecture, Ankara.

Perez, Nissan N. 1988. Focus East: Early Photography in the Near East (1839-1885)Published by Abradale/Abrams.

Perlmutter, David D. 1998. Photojournalism and Foreign Policy: Icons of Outrage in International Crises. Westport, Connecticut, London: Praeger.

Phillips, Sarah. Journalist. 2011. Photographer Jodi Bieber's Best Shot. Nov 20, accessed 22 Jan 2017.

https://www.theguardian.com/artanddesign/2011/nov/20/photography-jodi-bieber-best$\underline{\text { shot }}$

Pogány, Stephen. 2015. Viktor Orbán, Refugees and The Threat To Europe. Nov 2, accessed 5 Feb 2017.

https://www.socialeurope.eu/2015/11/viktor-orban-refugees-and-the-threat-to-europe/

Provencher Langlois, Marion. 2015. Discussing Refugee Women: Speechlessness, Helplessness and Bodies-as-Facts. Inquiries Journal/Student Pulse 7 (08), accessed 18 April 2016.

https://www.inquiriesjournal.com/articles/1060/2/discussing-refugee-womenspeechlessness-helplessness-and-bodies-as-facts

Quach, Tiffany. 1985. Problematic Issues of Objectification, Documentary and Art in Blind Woman from the region of Gondan, Mali, 1985 by Sebastião Salgado, accessed 2 Feb

http://web.stanford.edu/group/journal/cgi-bin/wordpress/wp-

content/uploads/2012/09/Quach_Hum_2010.pdf

Ranciere, Jacques and Steve Corcoran. 2009. Dissensus: On Politics and Aesthetics. London: Continuum.

Reinhardt, Mark, Holly Edwards, and Erina Dugganne. 2007. Beautiful Suffering: Photography and the Traffic in Pain. Williamstown, MA; Chicago: Williams College Museum of Art in association with the University of Chicago Press.

Ritchin, Fred. 1999. In Our Own Image: The Coming Revolution in Photography: How Computer Technology Is Changing Our View of the World. Writers and Artists on Photography. 2nd ed. New York: Aperture.

- 2009. After Photography. 1st ed. New York: W.W. Norton.

-2013. Bending the Frame: Photojournalism, Documentary, and the Citizen. Aperture Ideas: Writers and Artists on Photography. First edition, ed. New York, N.Y: 
Aperture Foundation, Inc.

Rosler, Martha. Decoys and Disruptions: Selected Writings, 2004. 1975-2001. Cambridge, Mass.; London: MIT.

Said, Edward W. Orientalism. 1979. 1st Vintage Books ed. New York: Vintage Books.

Salgado, Sebastião, Eduardo Galeano, Fred Ritchin. 1990. An Uncertain Grace. San Francisco Museum of Modern Art. New York, N.Y.: Aperture Foundation.

Sardar, Ziauddin. 1999. Orientalism. Buckingham: Open University Press.

Sischy, Ingrid. 1991. "Good Intentions" The New Yorker, 9 September, New York: Aperture.

Smith, Aileen Mioko. 2001. Aileen Archive - The Photograph "Tomoko and Mother in the Bath" - Statement by Aileen Smith. July 5, accessed 16 Jan 2017.

http://aileenarchive.or.jp/aileenarchive_en/aboutus/_pdf/060421_Tomoko.pdf

Solley, George C., Major, USMC. 1987. Israel's Lebanon War, 1982-1985. The Israeli Experience in Lebanon, 1982-1985. Marine Corps Command and Staff College. Marine Corps Development and Education Command. Quantico, Virginia. February 16, accessed $23 \quad$ Jan 2017. http://www.globalsecurity.org/military/library/report/1987/SGC.htm

Sontag, Susan. 1978. On Photography. London: Allen Lane.

_ 2003. Regarding the Pain of Others. London: Hamish Hamilton.

Stallabrass, Julian. 1997. Sebastião Salgado and Fine Art Photojournalism, New Left Review I/223, May-June 1997.

— (editor). 2013. Memory of Fire: Images of War and the War of Images. Photoworks.

Suleiman, Jaber. April 2006. Marginalised Community: The Case of Palestinian Refugees in Lebanon Development Research Centre on Migration, Globalisation and Poverty. University of Sussex.

Tériade, E. 1952. Henri Cartier-Bresson, Images à la Sauvette (Verve, 1952), Initated by the French publisher Tériade. Henri Cartier-Bresson Foundation, accessed $20 \quad$ Jan 2017. http://www.henricartierbresson.org/wp-content/uploads/2016/12/Press-Kit-Imagesa\%CC\%80-la-Sauvette-FHCB-GB.pdf

Thielman, Sam. Journalist. 13 Jan 2016. Al-Jazeera America to shut down after less than three years on air. Accessed: 13 January 2016.

https://www.theguardian.com/media/2016/jan/13/al-jazeera-america-shut-down-cabletv-news-network

Wells, Liz. 2000. Photography: A Critical Introduction. 2nd ed. London: Routledge. 
Wilson, Laura and Avedon, Richard. 2003. AVEDON AT WORK - In the American West by University of Texas Press.

Woodward, Michelle L. 2003, Between Orientalist Cliches and Images of Modernization Photographic Practice in the Late Ottoman Era History of Photography. Vol 27, No.4, Winter 2003, p363-374, accessed 7 July 2016. http://www.mwoodward.com/HistoryPhotography_Woodward.pdf

2017. Photorientalist, A Website dedicated to exhibiting $19^{\text {th }}$ and $20^{\text {th }}$ century photographs of the Middle East and North Africa, accessed 8 July 2016 http://www.photorientalist.org/about/orientalist-photography/

UNHCR REPORT, February 2016. The Situation of Palestinian Refugees in Lebanon, accessed 22 July 2016.

http://www.refworld.org/pdfid/56cc95484.pdf

UNWRA, Shatila Camp, accessed 30 July 2016.

https://www.unrwa.org/where-we-work/lebanon/shatila-camp 


\section{Appendix 1}

\section{NPPA CODE OF ETHICS}

\section{Preamble}

The National Press Photographers Association, a professional society that promotes the highest standards in visual journalism, acknowledges concern for every person's need both to be fully informed about public events and to be recognized as part of the world in which we live.

Visual journalists operate as trustees of the public. Our primary role is to report visually on the significant events and varied viewpoints in our common world. Our primary goal is the faithful and comprehensive depiction of the subject at hand. As visual journalists, we have the responsibility to document society and to preserve its history through images.

Photographic and video images can reveal great truths, expose wrongdoing and neglect, inspire hope and understanding and connect people around the globe through the language of visual understanding. Photographs can also cause great harm if they are callously intrusive or are manipulated.

This code is intended to promote the highest quality in all forms of visual journalism and to strengthen public confidence in the profession. It is also meant to serve as an educational tool both for those who practice and for those who appreciate photojournalism. To that end, The National Press Photographers Association sets forth the following. Visual journalists and those who manage visual news productions are accountable for upholding the following standards in their daily work:

1. Be accurate and comprehensive in the representation of subjects.

2. Resist being manipulated by staged photo opportunities.

3. Be complete and provide context when photographing or recording subjects. Avoid stereotyping individuals and groups. Recognize and work to avoid presenting one's own biases in the work.

4. Treat all subjects with respect and dignity. Give special consideration to vulnerable subjects and compassion to victims of crime or tragedy. Intrude on private moments of grief only when the public has an overriding and justifiable need to see. 
5. While photographing subjects do not intentionally contribute to, alter, or seek to alter or influence events.

6. Editing should maintain the integrity of the photographic images' content and context.

not manipulate images or add or alter sound in any way that can mislead viewers or misrepresent subjects.

7. Do not pay sources or subjects or reward them materially for information or participation.

8. Do not accept gifts, favors, or compensation from those who might seek to influence coverage.

9. Do not intentionally sabotage the efforts of other journalists.

\section{Ideally, visual journalists should:}

1. Strive to ensure that the public's business is conducted in public. Defend the rights of access for all journalists.

2. Think proactively, as a student of psychology, sociology, politics and art to develop a unique vision and presentation. Work with a voracious appetite for current events and contemporary visual media.

3. Strive for total and unrestricted access to subjects, recommend alternatives to shallow or rushed opportunities, seek a diversity of viewpoints, and work to show unpopular or unnoticed points of view.

4. Avoid political, civic and business involvements or other employment that compromise or give the appearance of compromising one's own journalistic independence.

5. Strive to be unobtrusive and humble in dealing with subjects.

6. Respect the integrity of the photographic moment.

7. Strive by example and influence to maintain the spirit and high standards expressed in this code. When confronted with situations in which the proper action is not clear, seek the counsel of those who exhibit the highest standards of the profession. Visual journalists should continuously study their craft and the ethics that guide it. 
Appendix 2

PRACTICAL COMPONENT - REMEMBER SHATILA

All Photos by Zann Huizhen Huang Copyright $2017 \underline{6}$
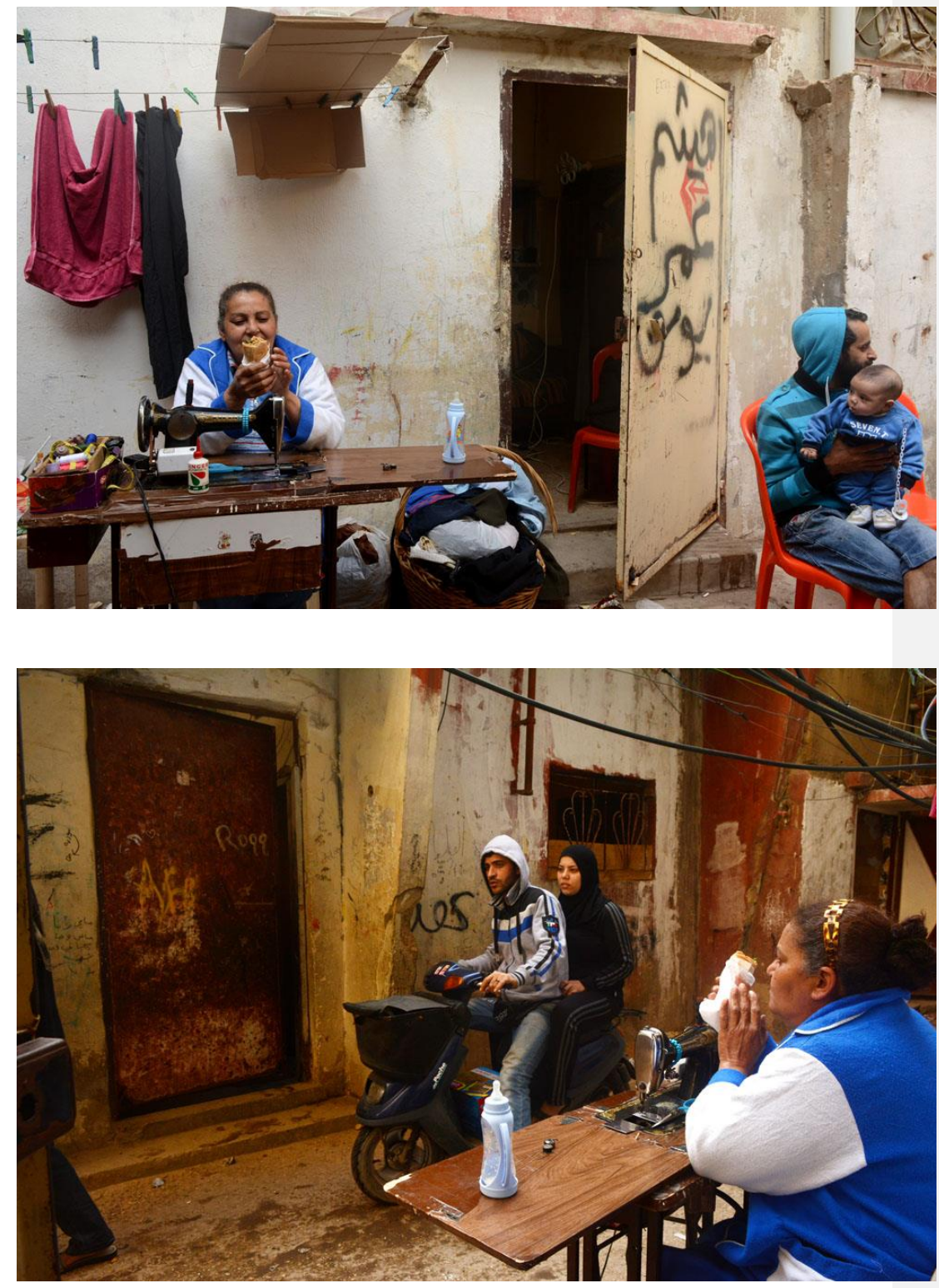

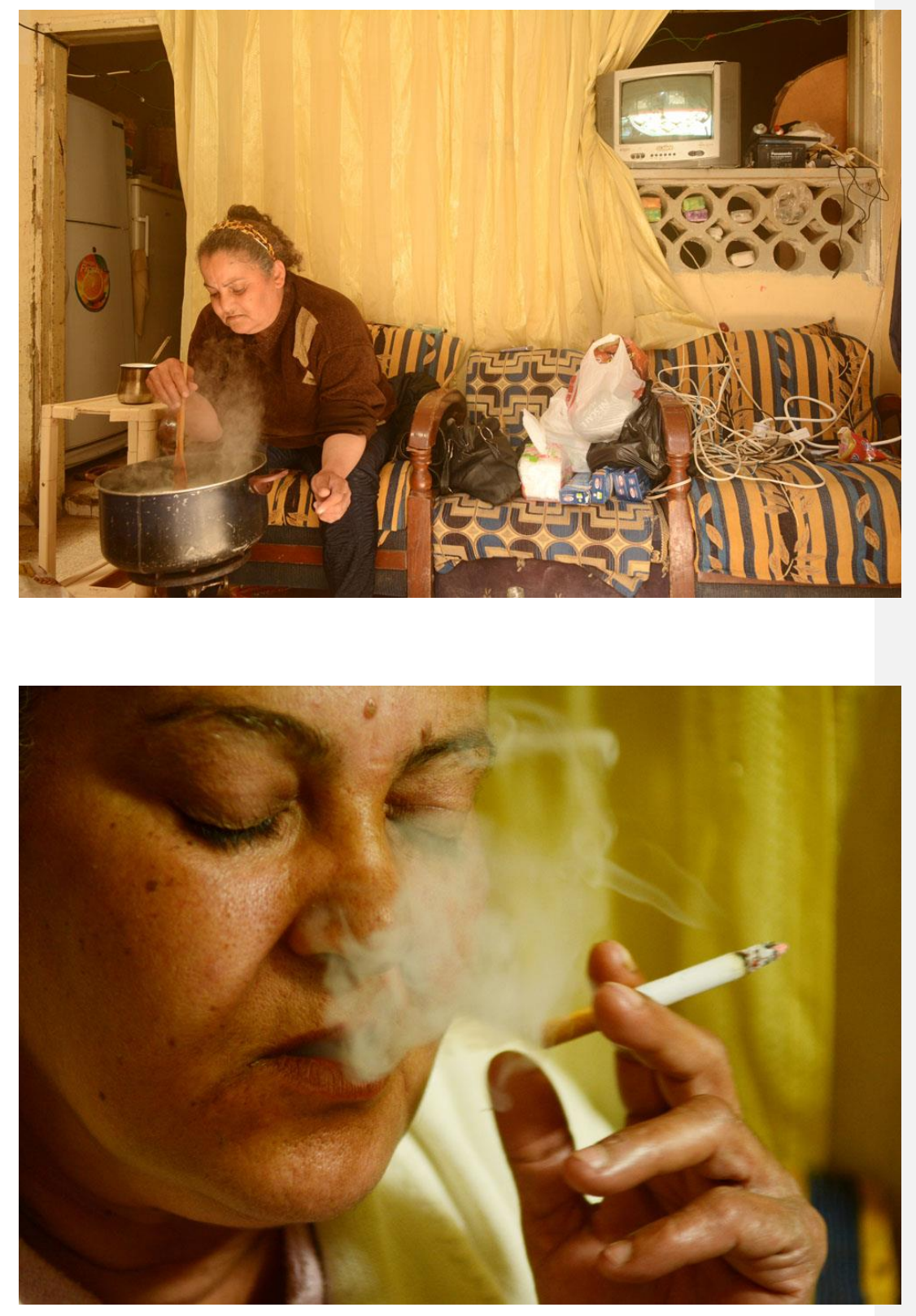

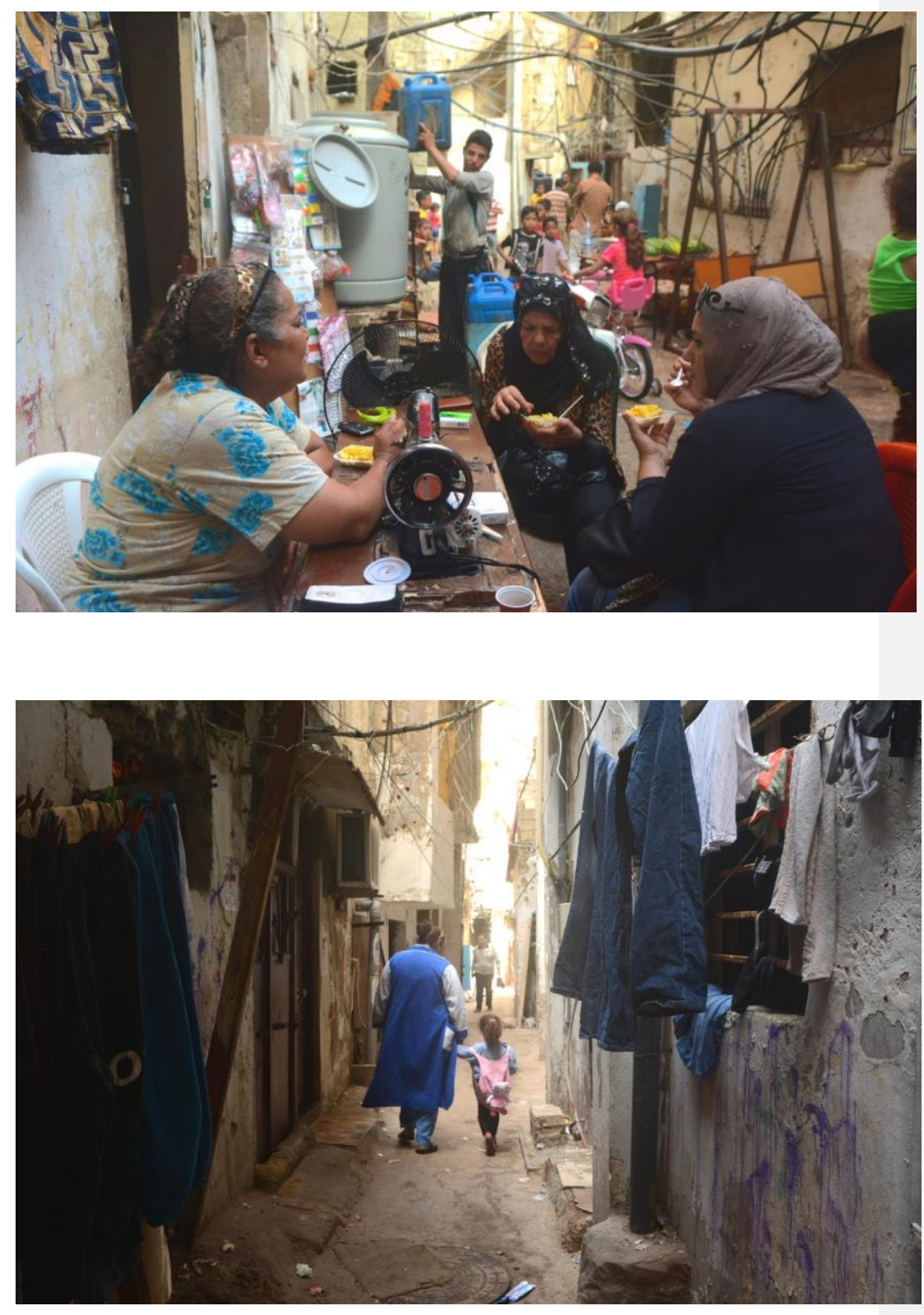

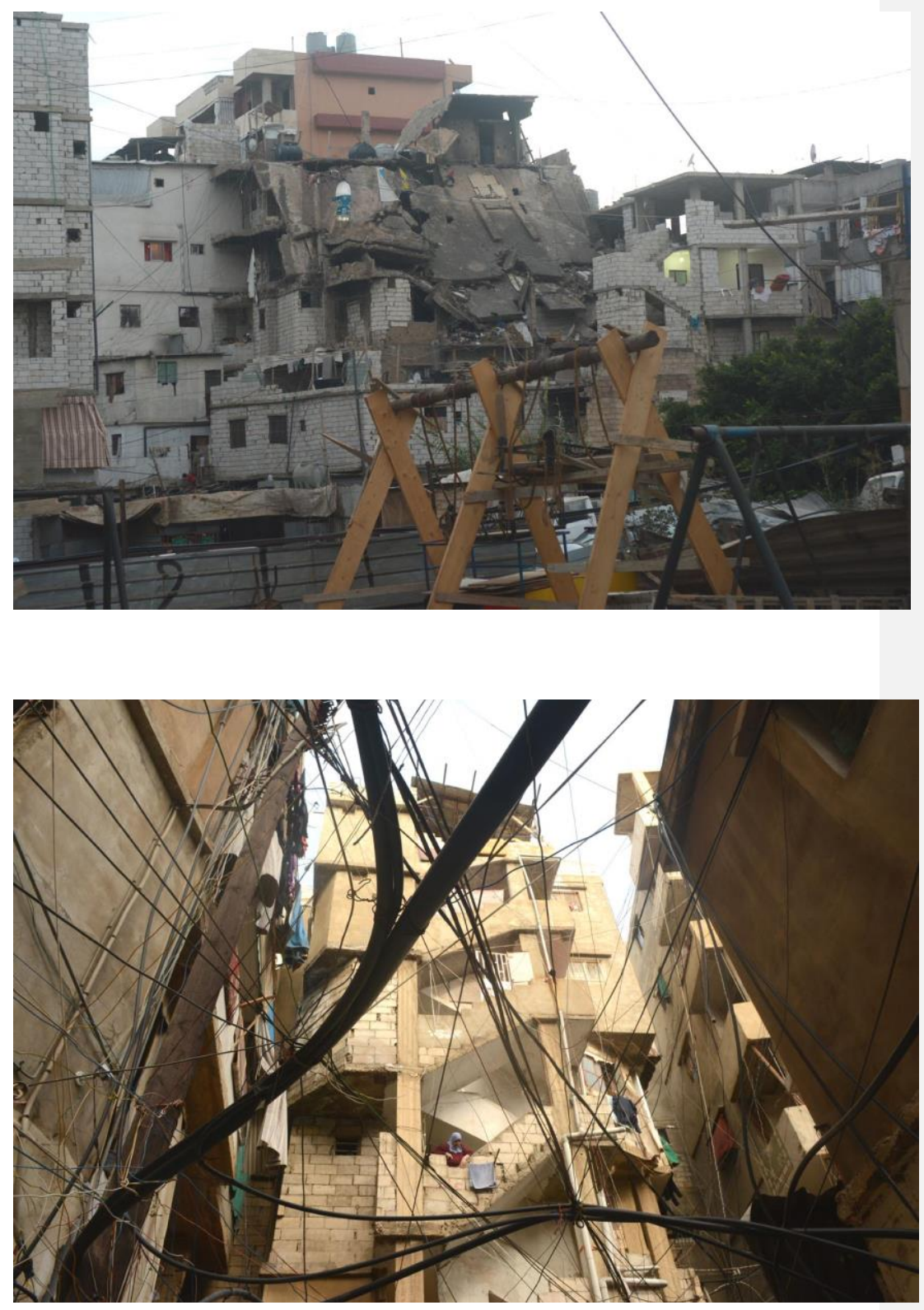